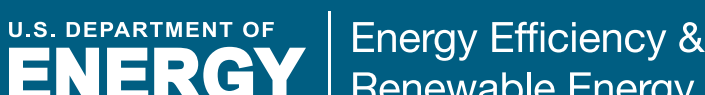

Renewable Energy

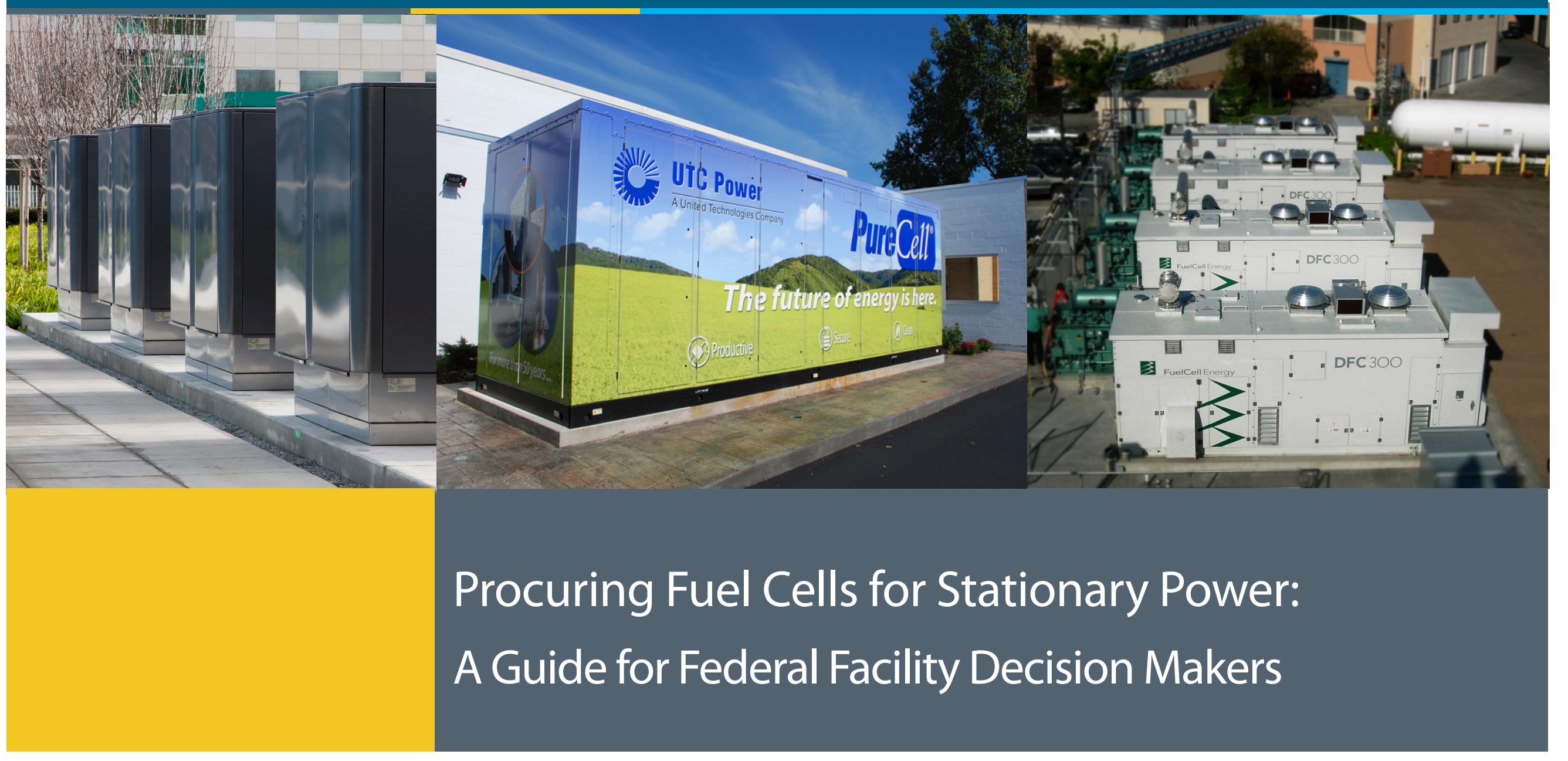

Fuel Cell

Technologies Program
Oak Ridge

National Laboratory 
Available electronically at www.eere.energy.gov/hydrogenandfuelcells/ fc_publications.html\#fe_stationary

Available for a processing fee to U.S. Department of Energy and its contractors, in paper, from:

\section{U.S. Department of Energy}

Office of Scientific and Technical Information P.O. Box 62

Oak Ridge, TN 37831-0062

phone: 865.576 .8401

fax: 865.576 .5728

email: reports@adonis.osti.gov

Available for sale to the public, in paper, from:

\section{U.S. Department of Commerce National}

Technical Information Service

5285 Port Royal Road

Springfield, VA 22161

phone: 800.553 .6847

fax: 703.605 .6900

email: orders@ntis.fedworld.gov

online ordering:

www.ntis.gov/help/ordermethods.aspx

\section{NOTICE}

This report was prepared as an account of work sponsored by an agency of the United States government. Neither the United States government nor any agency thereof, nor any of their employees, makes any warranty, express or implied, or assumes any legal liability or responsibility for the accuracy, completeness, or usefulness of any information, apparatus, product, or process disclosed, or represents that its use would not infringe privately owned rights. Reference herein to any specific commercial product, process, or service by trade name, trademark, manufacturer, or otherwise does not necessarily constitute or imply its endorsement, recommendation, or favoring by the United States government or any agency thereof. The views and opinions of authors expressed herein do not necessarily state or reflect those of the United States government or any agency thereof.

Cover Photos: Fuel cell installations by Bloom Energy (left), UTC Power (middle), Fuel Cell Energy (right) 


\title{
Procuring Fuel Cells for Stationary Power: A Guide for Federal Facility Decision Makers
}

\author{
Joseph McGervey \\ Sentech/SRA International \\ David Stinton \\ Oak Ridge National Laboratory
}

October 2011 


\section{FORWARD}

This document is intended to provide federal agencies with initial guidance on how to procure energy from fuel cell combined heat and power (CHP) technology. It is not meant to replace agency-specific legal guidance. This document is based on best practices and the experience of agency personnel and laboratory and industry collaborators. Each agency, however, develops internal rules and regulations regarding procurement, therefore it is important to emphasize that the experiences and outcomes vary greatly. Additionally, different federal statutes govern long-term energy purchases. For example, there are substantial differences between statutes for military agencies as compared to those for most civilian agencies. Further, the procurement of fuel cells in the federal sector (as well as in U.S. market sectors) is a dynamic and rapidly evolving industry. As federal agencies work to navigate their own procurement rules, many others in the fuel cell industry also endeavor to understand how to incorporate sophisticated financing models and legal agreements into the federal procurement process. It therefore is vital to acknowledge that new lessons, information, and projects likely will develop in the future, and could provide new or different guidance not included in this document.

$\sim$ Pete Devlin, DOE Fuel Cell Technologies Program

For the most current version of this guide, visit www.eere.energy.gov/hydrogenandfuelcells/fc_publications.html\#fc_stationary. 


\section{Acknowledgments}

A special thank you to Pete Devlin and Nancy Garland (U.S. Department of Energy [DOE], Fuel Cell Technologies Program) and Will Lintner (DOE Federal Energy Management Program) for their material support, advice, and feedback.

For contributing time, expertise, and content, the authors thank John Christensen (Christensen Consulting Group LLC), Stephanie Byham (SRA International), Greg Moreland (SRA International) and Renae Steichen (SRA International).

For thoughtful review of the guide resulting in vital feedback, the authors thank Frank Wolak (FuelCell Energy Inc.), Sam Logan (LOGANEnergy Corp.) and Keith Spitznagel (LoganEnergy Corp.). The authors also thank Mike Penev (National Renewable Energy Laboratory), Jack Brouwer (University of California, Irvine), Richard Shaw (UTC Power), Bob Gemmer (DOE Industrial Technology Program), Will Lintner (DOE Federal Energy Management Program), Josh Richmond (Bloom Energy), and Asim Hussain (Bloom Energy).

For comprehensive editing, publication, and Web support, we are grateful to Ashley Smith (Sentech/ SRA International) and Sheena Henderson (Sentech/SRA International).

The DOE Fuel Cell Technologies Program (FCT) provided the funding for this report. 


\section{Contents}

Executive Summary.

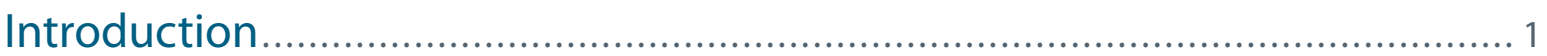

How Fuel Cell Stationary Power Can Help Federal Facilities ............................ 3

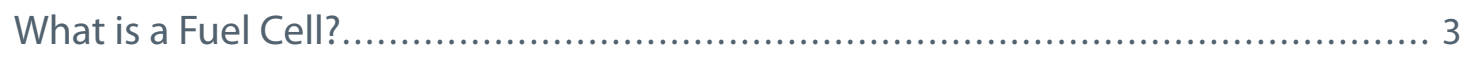

Basic Fuel Cell Processes and Components ......................................................... 4

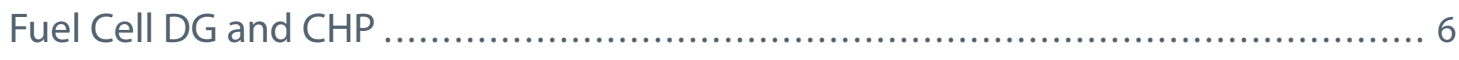

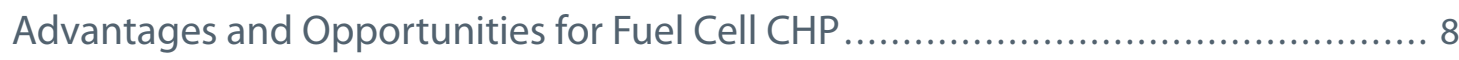

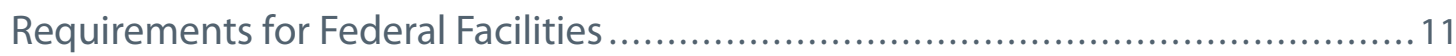

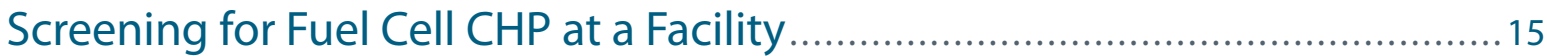

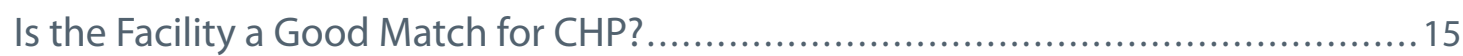

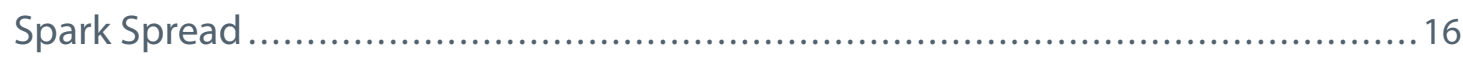

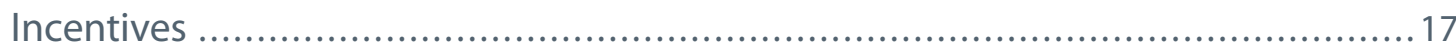

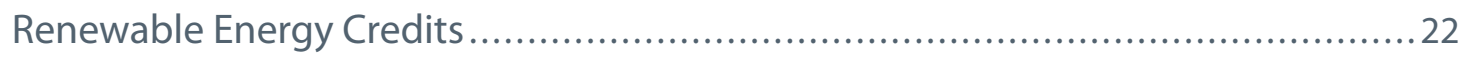

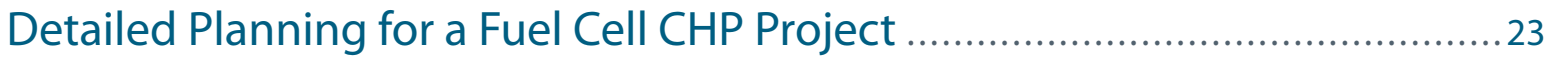

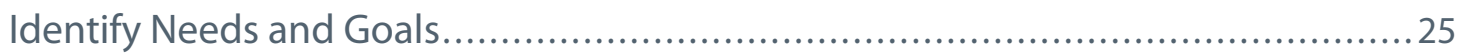

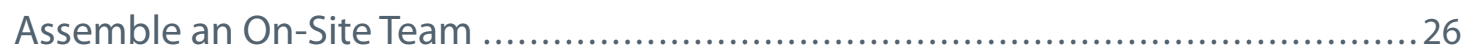

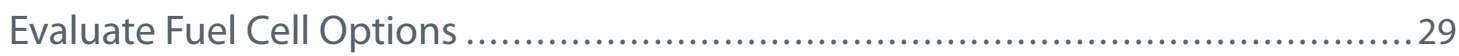

Consider Project Requirements and Recommendations...................................... 30 


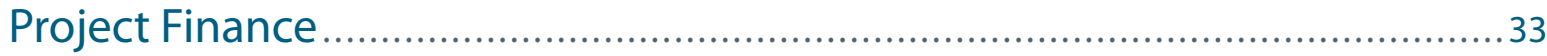

Power Purchase Agreement (PPA) ...................................................... 34

Energy Savings Performance Contract (ESPC)........................................ 34

Utility Energy Services Contract (UESC)................................................ 34

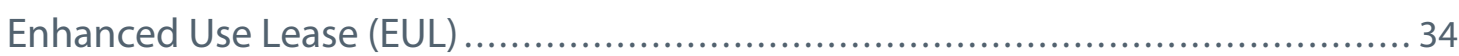

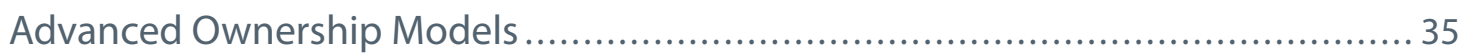

Execution of a Fuel Cell Project................................................................ 37

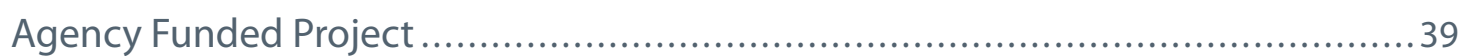

Power Purchase Agreement (PPA) ....................................................... 42

Energy Savings Performance Contract (ESPC)........................................ 51

Utility Energy Services Contract (UESC) ............................................. 54

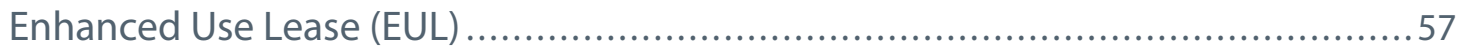

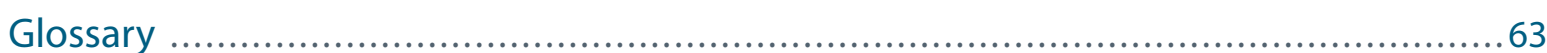

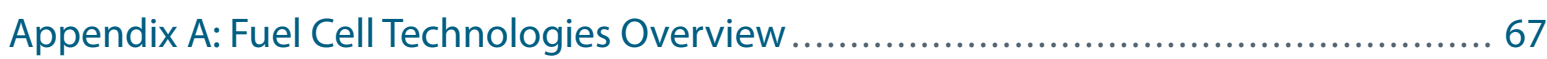

Appendix B: Screening Calculations, \& Checklists ............................................69

Appendix C: FEMP Factsheet: Fuel Cell Financing for Tax Exempt Entities ................... 73

Appendix D: Factsheets for Fuel Cell CHP Projects .............................................. 76

Appendix E: Listing of States and Types of Incentives for Fuel Cells ........................81

Appendix F: Acronyms and Abbreviations ............................................. 83 


\section{Executive Summary}

The potential use of fuel cell technologies at federal sites is currently gaining more and more attention due to their potential to enhance critical systems performance, to meet executive branch sustainability targets, and to promote a clean energy technology. Fuel cell systems can use either natural gas or renewable fuels (i.e., biogas), and fuel-cell-driven combined heat and power (CHP) systems can deliver reliable electricity and heat with up to $90 \%$ efficiency. When fuel cells are primarily being used for power, the heat they generate can be used internally to reform fuel and achieve up to $60 \%$ efficiency in distributed generation applications.

Fuel cell CHP technology can also help managers comply with Federal agency objectives to reduce energy consumption and air pollution emissions. Fuel cells do not generate particulate pollutants, unburned hydrocarbons, or the gases that produce acid rain. They emit less carbon dioxide than other less efficient technologies, and their use with renewable fuels can make them carbonneutral. Furthermore, fuel cells have a small physical footprint and make little noise.

Implementation of these technologies can provide highly efficient, clean energy solutions for agencies striving to meet ambitious sustainability requirements with limited budgets; however, because fuel cell technologies require up-front capital for purchase scenarios, their deployment poses unique challenges. In addition, fuel cells must be integrated into a facility's existing/other energy systems so that their efficiency benefits can be realized. Fuel cell projects, nevertheless, show promise as technology improvements, cost reductions, and experienced project developers continue to make them easier to implement.

This guide is intended to assist the leadership of federal agencies in making smart purchasing decisions - without the need for extensive expertise in the fuel cell technology industry. It describes the following innovative financing mechanisms to procure fuel cell systems with little or no capital investment:

- Power purchase agreements (PPA)

- Energy savings performance contracts (ESPC)

- Utility energy services contracts (UESC)

- Enhanced use leasing (EUL)

Although the simplest procurement method is designated funding for the outright purchase of the fuel cell system, this is usually not the most cost-effective option because federal entities are not eligible for investment tax credits.

This guide also provides an overview of the process required for planning and implementing a fuel cell project. Presented in a concise, step-bystep format, federal decision makers will be more easily able to translate their interest in fuel cell technologies into successful installations.
Note that only larger $(\geq 100 \mathrm{~kW})$ stationary fuel cell systems are addressed here and that possible smaller-scale applications (e.g., cars, forklifts,

backup power supplies, small generators) are not considered in this document. 


\section{Introduction}

This step-by-step manual guides readers through the process of implementing a fuel cell stationary power project. The guide outlines the basics of fuel cell technology and describes how fuel cell projects can meet on-site energy service needs as well as support strategic agency objectives and sustainability requirements. This guide will help agencies decide whether a fuel cell project may be feasible and economically viable at their site. The guide then presents a four-part process for implementing a fuel cell project. Each part has several subparts and considerations.

Part 1 guides facility managers through a preliminary screening process to help managers decide whether it may be worthwhile to invest time in investigating fuel cell stationary power for their facility. Part 2 is a more thorough set of steps and includes defining their energy needs to deciding to move forward with a project. In Part 3 , the options for financing and contracting for a project are explained as well as the selection process most appropriate for their situation.

Part 4 follows the process for each financing and contracting option to the end of the project. This guide presents the major components of successful fuel cell projects so that readers can achieve their own fuel cell energy goals, which might include a single facility installation, a multi-facility procurement, or an agency-wide procurement plan, among others.
Supplemental information for this guide can be found in the appendices. Appendix A presents technology descriptors for different kinds of fuel cells. Appendix B contains a step-by-step, self-guided fuel cell CHP screening checklist, along with several other types of checklists. Appendix $\mathrm{C}$ is a factsheet on fuel cell financing for tax exempt entities. Appendix D is a factsheet for fuel cell CHP projects. Appendix E is a listing of states and types of incentives for fuel cells. Appendix F lists the acronyms and abbreviations used in this guide.

Having a fuel cell project champion who can help clear project barriers and see the project through to completion is of particular importance. This champion can come from many areas, such as facility or regional management, headquarters leadership, or another leadership area. But no matter where a champion is found, he or she must help move the project forward and overcome barriers that might otherwise stop or delay a project. Experience has shown that strong project leadership is a critical factor in successful fuel cell projects.

Although this guide focuses on fuel cell projects, it is important to note that energy efficiency is important for reducing both site energy costs and the environmental impacts of using conventional methods of energy production.
The U.S. Department of Energy (DOE) Fuel Cell Technologies Program (FCT) can provide assistance or answer questions about fuel cell CHP or energy efficiency projects. Call 877-EERE-INFO (877-337-3463) or visit www.eere.energy.gov/informationcenter/ for more information. 
2 October 2011 


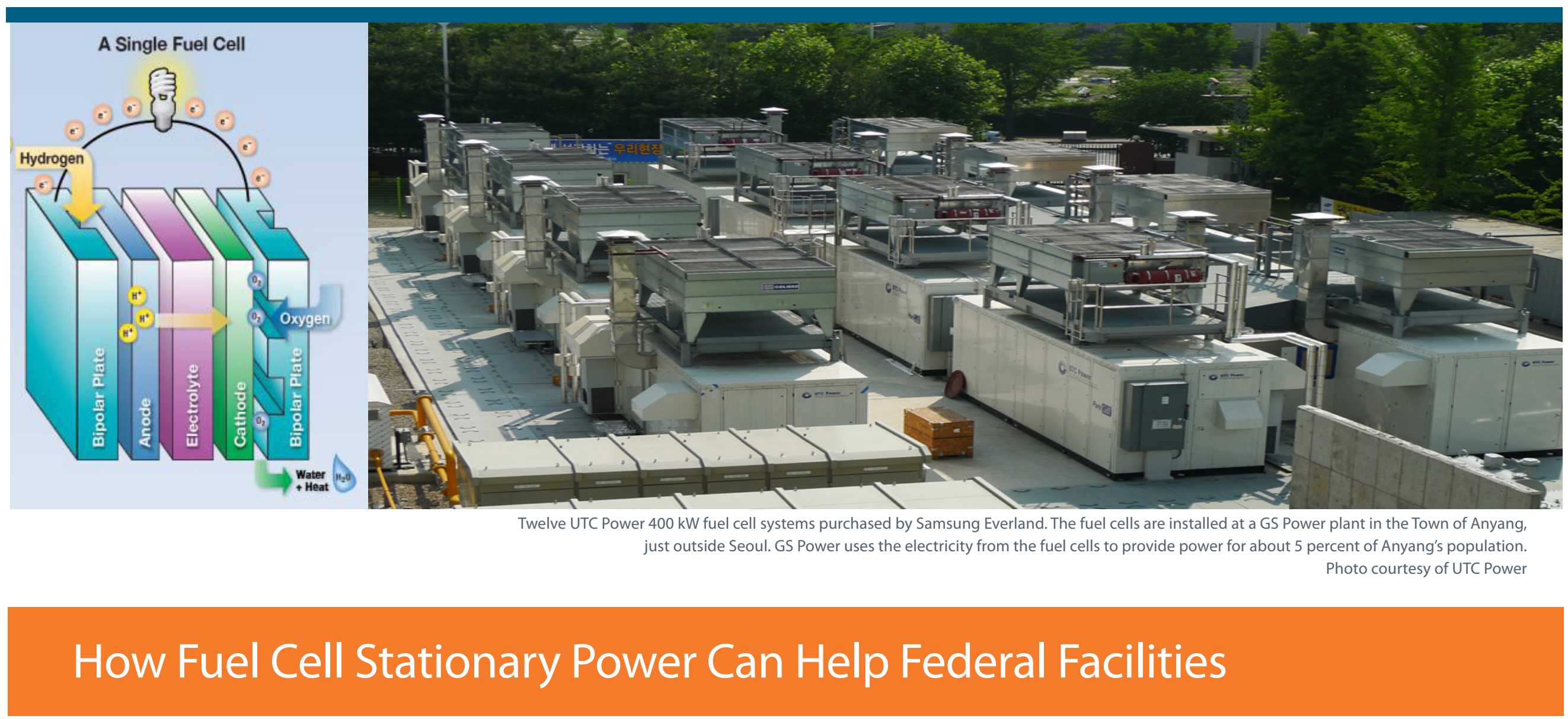

\section{What is a Fuel Cell?}

Fuel cells produce electricity through an electrochemical process, much like a household or automotive battery, making them distinct from traditional power generators, such as engines or turbines, which use a combustion process. In fact, the first fuel cells used in the space program were alkaline fuel cells derived from the standard alkaline battery. Whereas a spent standard battery must be recharged or discarded, a fuel cell can generate energy (heat and/or power) using a continuous fuel supply (like a natural gas pipeline).

Fuel cells consume hydrogen and oxygen in a process that is completely electrochemical, with no flame or combustion. Hydrogen typically is reformed from natural gas supplied from a pipeline or an on-site storage tank. It can also be generated from on-site hydrocarbons, such as from biogas from

\section{At-a-Glance}

Details on what's included in this section

1. What is a Fuel Cell?

2. Basic Fuel Cell Processes and Components

3. Fuel Cell CHP

4. Advantages/Opportunities for Fuel Cell CHP

5. Requirements for Federal Facilities 
wastewater treatment operations or landfills.

Fuel cells generate electricity, heat, and water with near zero emissions.

Fuel cells are very efficient in converting fuel into electricity with electrical efficiencies of $35 \%$ to $55 \%$. By comparison, pulverized coal plants are $30 \%$ to $40 \%$ efficient, natural gas turbines systems are 30 to $45 \%$ efficient, and microturbine systems are $28 \%$ to $35 \%$ efficient. ${ }^{1,2}$ In addition, on-site systems avoid the losses that occur as electricity is transmitted from a central generating station to the customer. Fuel cells are well-suited to provide reliable electric and thermal energy services for Federal facilities. Two terms are used in this document to describe on-site fuel cell installations:

- Distributed generation (DG) describes small, on-site systems that produce all or part of the electricity that a facility needs to operate, taking the place of purchased electricity from the grid. DG systems include fuel cells, engines, turbines/microturbines, and other technologies.

\section{- Combined heat and power (CHP) is} a subset of DG. CHP systems produce electricity and thermal energy, such as steam, hot water, or chilled water. CHP simultaneously produces electrical and thermal energy at much higher efficiencies and lower costs than conventional, separate production at a central power plant or on-site boiler/water heater.

\section{Basic Fuel Cell Processes and Components}

Fuel cells use a variety of different electrochemical processes to generate electricity from hydrogen.

Fuel cell CHP systems larger than $100 \mathrm{~kW}$ are commercially available using three types of technologies: molten carbonate fuel cells
(MCFC), phosphoric acid fuel cells (PAFC), or solid oxide fuel cells (SOFC).

A more complete description of these fuel cell technologies is contained in Appendix A.

All fuel cell systems are composed of three primary subsystems that perform similar functions, regardless of the specific fuel cell technologies:

1) Fuel processor: prepares the fuel (natural gas) for use in the fuel cell stack

2) Fuel cell stack: generates direct current (DC) electricity

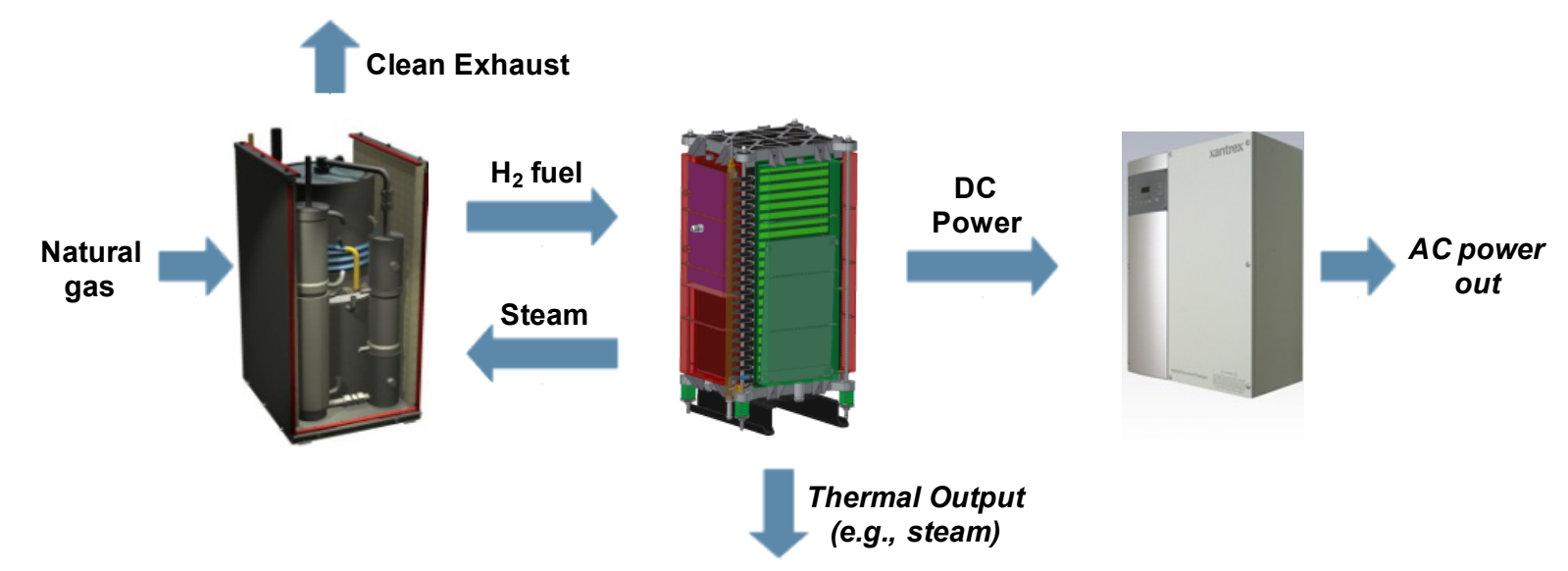

\section{Fuel Processor Fuel Cell Stack Power Conditioner}

Figure 1. Major Subsystems of a Fuel Cell CHP System

DOE Energy Information Administration, “Assumptions to the Annual Energy Outlook 2010," DOE/EIA-0554(2010), April 2010

'DOE Energy Information Administration, "Assumptions to the Annual Energy Outlook 2010," DOE/EIA-0554(2010), April 2010 (LHV - which does not include the heat of condensation of the water vapor in the products) is often used. The HHV is greater than the LHV by approximately $10 \%$ with natural gas as the fuel (i.e., $50 \%$ LHV is roughly the same as $45 \% \mathrm{HHV}$ ). 
3) Power conditioner: processes the $\mathrm{DC}$ electricity into alternating current $(\mathrm{AC})$

Figure 1 shows the primary subsystems in a fuel cell CHP system. Similar to other fuel cell CHP systems, the three primary subsystems are integrated into a single system, which consumes fuel (usually natural gas) and produces electricity and useful thermal energy.

\section{Fuel Cell Stack}

Simplified schematics of the three fuel cell types are illustrated in Figure 2. A single fuel cell has three components: a cathode (positively charged electrode), an anode (negatively charged electrode), and an electrolyte. Hydrogen $\left(\mathrm{H}_{2}\right)$ is supplied to the anode and oxygen $\left(\mathrm{O}_{2}\right)$ to the cathode. Depending on the type of fuel cell, different reactions occur and freed electrons flow out of the anode, forming the flow of electrons that is the DC electricity.

The type and direction of the flow of ions between the anode and cathode varies with the type of fuel cell. In the PAFC, the reaction at the anode creates protons that flow through the electrolyte to the cathode. In the MCFC, carbonate ions are transferred from the cathode to the anode. In the SOFC, $\mathrm{OH}^{-}$ions are transferred from the cathode to the anode. Oxygen is supplied to the cathode, which catalyzes a reaction in which the oxygen combines with the ions carried by the electrolyte and the flow of electrons to form water $\left(\mathrm{H}_{2} \mathrm{O}\right)$.

All fuel cells have this overall chemical reaction:

$2 \mathrm{H}_{2}+\mathrm{O}_{2} \rightarrow 2 \mathrm{H}_{2} \mathrm{O}$ (vapor) + energy (electricity)

Because some of this energy takes the form of heat and there are several irreversabilities in the electrochemical reactions, not all of the theoretical energy becomes useful electrical output. The actual voltage output is less than the theoretical potential; usually between 0.55 and 0.80 volts. The difference between the actual voltage output of the fuel cell and the theoretical potential determines the fuel cell efficiency. The generation of heat is not without value, as some heat is needed for the fuel processing unit and the balance can provide useful thermal energy for the facility.

The typical output voltage of an individual fuel cell element is inadequate for almost any application. To generate sufficient voltage, a fuel cell must have hundreds of individual fuel cells arranged in a fuel cell stack. The fuel cell stack is assembled at the manufacturer and is designed to be replaced as a unit.

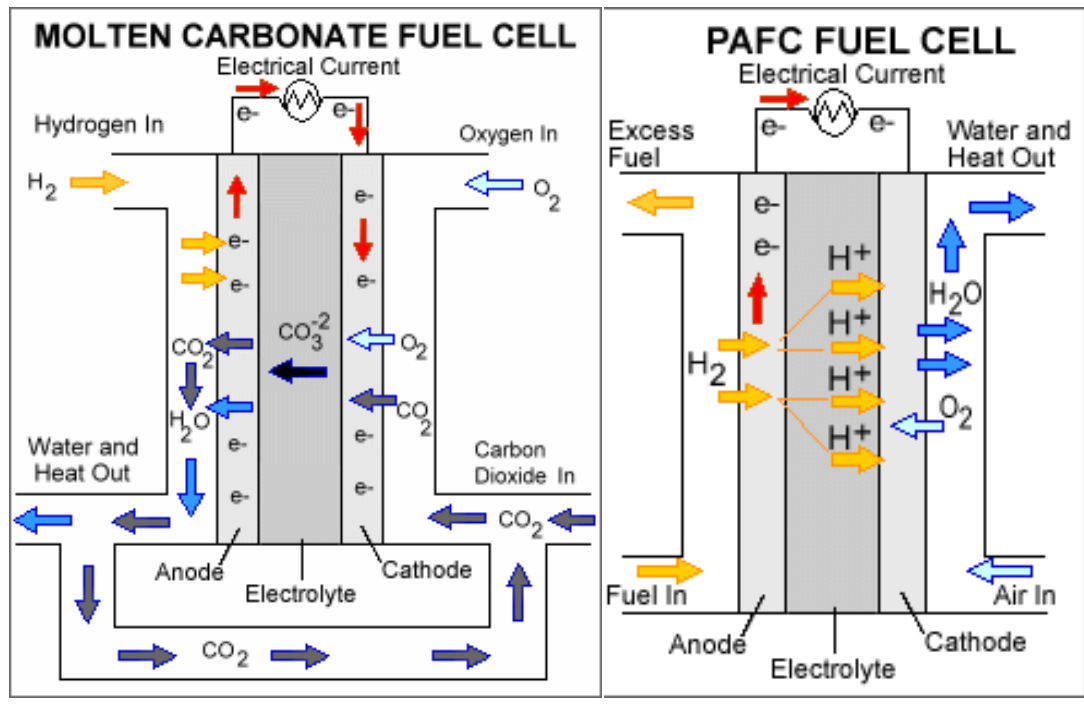

Construction: High-temperature metals, porus ceramics

Operating Temperature: $600-700^{\circ} \mathrm{C}$

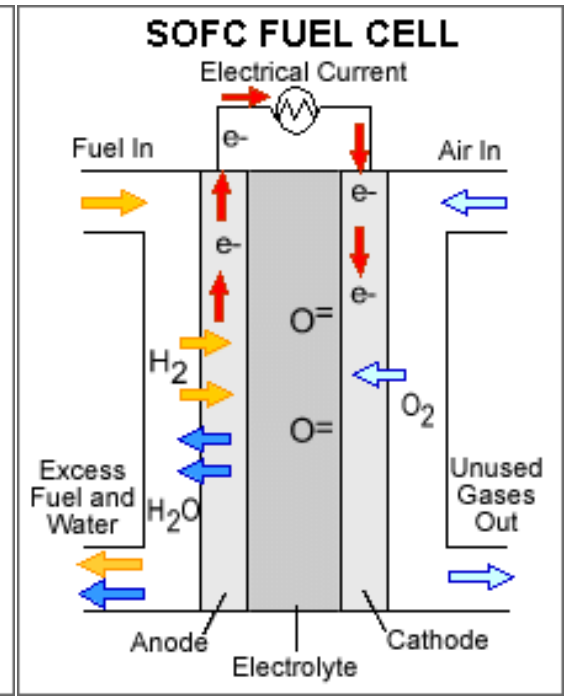

Construction: Ceramic, high-temperature metals

Operating Temperature: $500-1,000^{\circ} \mathrm{C}$

Figure 2. Three types of commercially available fuel cell technologies 
The conversion of a fuel (hydrogen) and oxygen to electricity is shared with other power generation technologies, but that is the limit of the similarities. Engines, combustion turbines, and microturbines combust the fuel in a flame, generating higher peak temperatures and producing more pollutants such as carbon monoxide (CO), oxides of nitrogen $\left(\mathrm{NO}_{\mathrm{x}}\right)$ and volatile organic compounds (unburned nonmethane hydrocarbons). Compared to electricity from the grid, fuel cell CHP systems have almost no sulfur dioxide $\left(\mathrm{SO}_{2}\right)$ emissions.

\section{Fuel Processor}

Although the fuel cell itself consumes hydrogen, CHP fuel cell systems primarily use natural gas, liquefied petroleum gas (LPG), or a renewable hydrocarbon source such as biogas. A fuel processor or reformer converts the fuel source into the hydrogen-rich gas stream that is supplied to the fuel cell stack. Fuel processors use oxygen to combine with the carbon in the fuel source, which frees the hydrogen to be consumed in the fuel cell stack.

For fuel cells that require a separate fuel processor, there are three main technology types: steam reformers, autothermal reformers, and partial oxidation reformers. Steam reformers use steam as an oxygen source, partial oxidation units use oxygen, and autothermal reformers use both steam and oxygen.
Steam reformers are the most common type used in fuel cells and share technology with the petrochemical industry. Steam and heat react with natural gas in the presence of a catalyst to produce hydrogen and carbon monoxide $(\mathrm{CO})$, which further react to produce a high purity hydrogen stream and carbon dioxide $\left(\mathrm{CO}_{2}\right)$. Partial oxidation reformers combust a portion of the natural gas fuel stream (partial oxidation) to produce heat and facilitate the separation into $\mathrm{CO}$ and hydrogen streams. Autothermal reformers use oxygen and $\mathrm{CO}_{2}$ or steam to split the fuel (natural gas) to produce a hydrogen-CO blend. The selection of reformers is a technical choice determined by the type of fuel cell, its operating temperature and the characteristics of the particular fuel cell installation.

\section{Power Conditioner}

Fuel cells generate DC electricity that must be conditioned to produce the $\mathrm{AC}$ required for most applications. Typical fuel cell CHP systems will produce 200 to 400 volts of DC power. This output is delivered to the power conditioning system, which performs several important functions. The power conditioner boosts the DC voltage to a higher voltage and delivers the power to an electronic inverter. The inverter applies a modulation technique at high frequencies to generate simulated $\mathrm{AC}$ output. The inverter controls the frequency of the output, which can be synchronized with grid power and/or be adjusted for direct on-site power consumption. Power conditioners are highly efficient with losses of $5 \%$ or less.

It should be noted that direct fuel cell power plants in California have been certified for gridinterconnection under U.L. 1741 and the state's 'Rule 21' standard, enabling them to meet the California Air Resources Board stringent new "ultra clean" emissions standards.* Such certifications enhance the eligibility of these plants for state incentive programs, and likewise, they promote acceptance of such certifications by major electric utilities in the United States.

\section{Fuel Cell DG and CHP}

Fuel cells can be used in DG (electricity-only) or CHP (electricity and thermal) applications. Fuel cells in DG applications can achieve efficiencies as high as $60 \%$. Although these systems do not deliver thermal services to the facility, the heat is recovered to internally reform the fuel to maximize efficiency.

Fuel cells deployed for CHP can achieve up to $90 \%$ efficiency by recovering the heat from electricity generation to produce useful steam, hot water, or chilled water. Fuel cell CHP systems can reduce $\mathrm{CO}_{2}$ emissions by $30 \%$ to $60 \%$ relative to the conventional approach (i.e., using grid electricity [from natural gas or coal] and on-site gas-fired boilers). More importantly, fuel cells can deliver electrical and

* http://www.energyvortex.com/pages/headlinedetails.cfm?id=886 
thermal energy services with greater reliability and lower cost than conventional systems. The initial capital costs may create challenges for federal facilities to make an outright purchase of a fuel cell CHP system, but creative financing arrangments that take advantage of incentives can make this technology viable.

Figure 3 illustrates the basic elements of a CHP system. In the most common application, natural gas fuels the fuel cell to generate electricity. The heat produced by a fuel cell can be captured and used to provide hot water, chilled water, space heating, or other thermal applications. In addition, the heat can be recovered to reform the fuel.

Thermal energy from the CHP system can eliminate (or supplement) an on-site boiler and the electricity can displace power from the grid. In some cases, a CHP system generates more power than a facility needs and excess electricity may be sold back to the utility. A fuel cell CHP system can reduce costs and increase efficiencies in many ways.

A CHP system recovers heat from electricity generation for productive uses. This heat is usually wasted at conventional power plants. Because the electricity is generated near the point of use, it is subject to fewer transmission losses than electricity supplied by distant central power plants. For these reasons, properly designed CHP systems can be more than twice as efficient as the average U.S. fossil fuel power plant. Growing numbers of federal facilities are turning to CHP technologies to gain greater control, reliability, supply quality, and flexibility in their power systems, as well as to cut costs and to meet Federal energy efficiency and emissions reductions goals.
Conventional conversion of fossil fuels to electricity produces large quantities of waste heat as a by-product; often one-half to twothirds of the energy is lost at the power plant. Conventional power plants simply emit the heat into the atmosphere through cooling towers or lakes and rivers.

Between the power plant and the customer, transmission and distribution of the electricity results in an additional $8 \%$ loss. The overall efficiency of grid-based electricity is as low as $31 \%$ because of the inefficiencies at the power plant and losses of delivering the power to the customer.

Successful projects 1) have a fairly constant thermal load throughout the year, 2) are located in areas with financial incentives, and 3) have access to a low-priced fuel source.

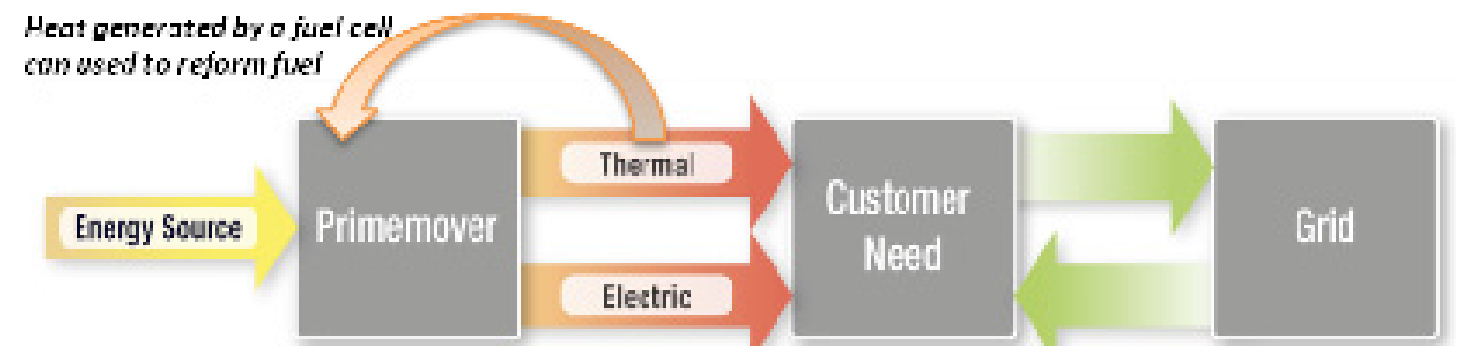

Figure 3. Basic Elements of a Combined Heat and Power (CHP) System 


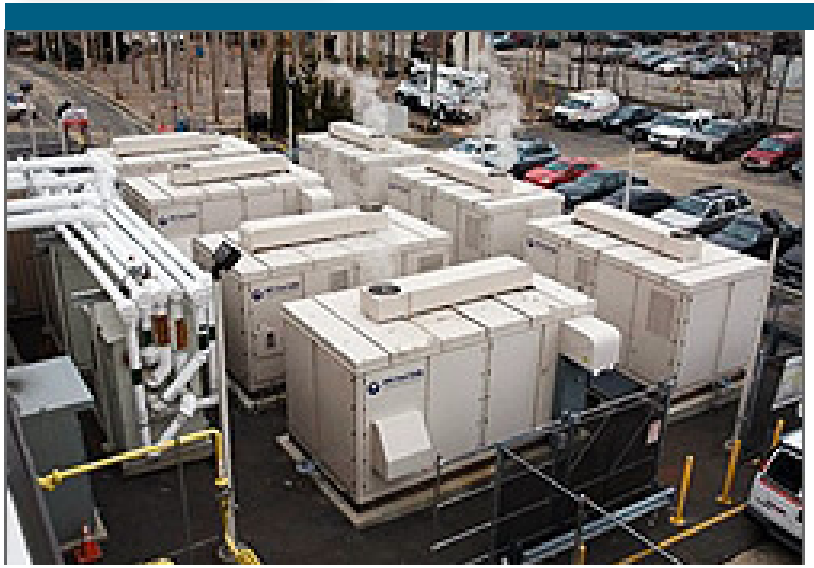

UTC Fuel Cells at Verizon Garden City

\section{Advantages and Opportunities of Fuel Cell $\mathrm{CHP}$}

Fuel cells are highly reliable and can deliver a steady supply of heat and power for gridconnected or grid-independent operations. Fuel cell CHP systems deliver other benefits that add value to the project through improved environmental or operational performance. Although these benefits can be difficult to quantify and include in a financial analysis, they represent an important part of the project development process.

Fuel cells have several advantages over the grid and conventional DG systems. Compared to engine and turbine CHP systems, fuel cells are quiet and have minimal emissions, allowing them to be strategically located near the point of energy demand. Superior environmental performance of fuel cells will help streamline the air permitting process. The modular design of a fuel cell facilitates the scaling of systems to match the energy demands of specific facilities. These features allow for the expansion of critical facilities and their related energy needs within existing building footprints.

\section{Reliability Benefits}

According to a 2008 report from the Defense Science Board Task Force on U.S. Department of Defense (DOD), "Fixed installations are 99\% dependent on the commercial power grid and other critical national infrastructure, which is fragile and vulnerable and poses serious risks to critical missions."

Fuel cell systems, when properly designed, deliver critical power while providing electric and thermal energy to the sites on a continuous basis. This reliability results in daily operating cost savings. Furthermore, interruptions in electricity from the grid can disrupt other, non-military operations. Power outages at grocery stores, for example, can cost hundreds of thousands of dollars. Power outages in other settings can result in safety and health risks that cannot be monetized.

Fuel cell systems are highly reliable. Recent energy service contracts have been based on a $95 \%$ availability, which includes scheduled downtime for maintenance. Unscheduled downtime is generally much less. Local grid reliability varies considerably, but fuel cell systems can meet a facility's energy requirements with reliability that can meet or exceed the performance of the grid. Compared to other clean energy sources that generate intermittently (i.e., wind or solar) fuel cell CHP provides reliable, steady power levels.

\section{Power Quality}

Fuel cell CHP systems can help overcome power quality issues. Voltage sags, frequency 
deviations, transient voltage, and distortions of the waveform are examples of power quality issues faced by many facilities relying on grid power. While most equipment tolerates these power quality deficiencies, critical equipment (including computing and communications equipment) may be disrupted or damaged by poor quality electricity.

Fuel cells generate DC power that is delivered to the power conditioning unit of the CHP system. The power conditioning unit raises the voltage and converts it to a high-quality $\mathrm{AC}$ power supply. Because voltage and waveform are managed by the power conditioning unit, the CHP system can deliver higher quality power than the grid.

\section{Peak Power}

Electricity consumption by facilities can vary considerably with fluctuating cooling, lighting, and office equipment power demands. High utility demand charges can be reduced through effective energy management and fuel cell CHP technologies that can reduce demand for grid power. Because CHP systems operate in baseload operations, they reduce power demand during all periods. However, the reduction in peak power demand achieved by the fuel cell CHP system is important, and its value should be included in the analysis of system benefits.

\section{Environmental Benefits}

It is estimated that building energy use generates $38 \%$ of U.S. greenhouse gas (GHG) emissions. As some of the largest single owners and occupants of buildings, federal agencies have the opportunity to greatly reduce $\mathrm{CO}_{2}$ emissions by implementing energy efficiency and renewable energy measures.*

Installing a fuel cell CHP system can both increase efficiency and reduce an agency's carbon footprint at the same time. Fuel cell CHP systems can reduce GHG emissions by up to $60 \% * *$ and virtually eliminate criteria air pollutants such as carbon monoxide (CO), nitrogen oxides $\left(\mathrm{NO}_{\mathrm{X}}\right)$, sulfur dioxide $\left(\mathrm{SO}_{2}\right)$, particulate matter, and unburned hydrocarbons. By installing a fuel cell system, an agency can generate electricity with very low on-site emissions and reduce the amount of electricity it needs to purchase.

Figure 4 shows a specific example of the GHG emissions savings from a $300 \mathrm{~kW}$ fuel cell CHP installation. The fuel cell CHP system has $40 \%$ to $50 \%$ lower GHG emissions because it uses energy more efficiently and because it uses a lower-carbon content fuel (natural gas) than the electricity grid (coal generates about $50 \%$ of all U.S. power). Furthermore, these systems can result in a 95\% reduction in criteria pollutants.

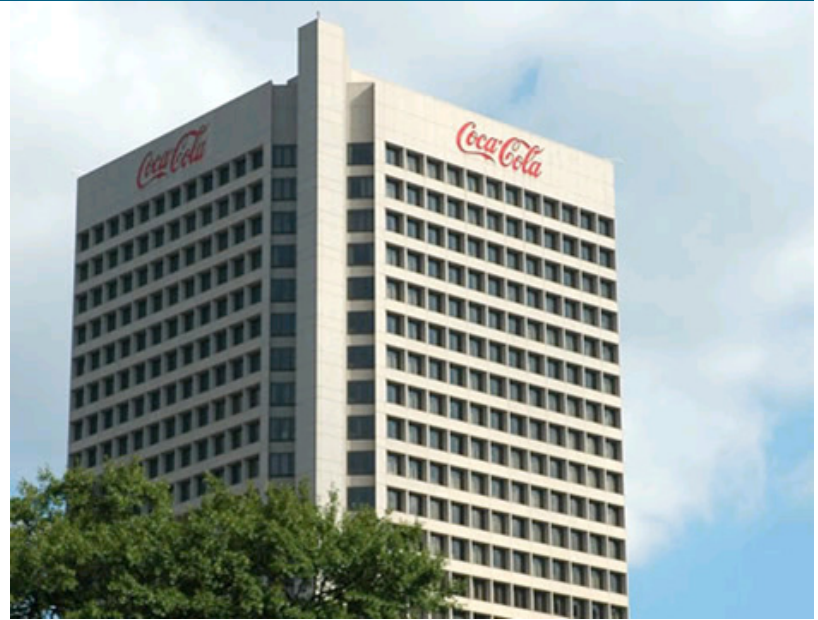

Coca-Cola Company has 500 kW Bloom Energy Servers installation at its Odwalla plant that runs on $100 \%$ renewable biogas and has reduced the plant's carbon footprint by and estimated $35 \%$.

* 2009 Buildings Energy Data Book, table 1.4.1; available at http://buildingsdatabook.eren.doe.gov/TableView.aspx?table=1.4.1 (accessed July 9, 2010)

** U.S. DOE. Fuel Cell Technologies Record \#1 1006. "Fuel Cells for Combined Heat \& Power - CO2 and NOx Emissions." July 2011. 


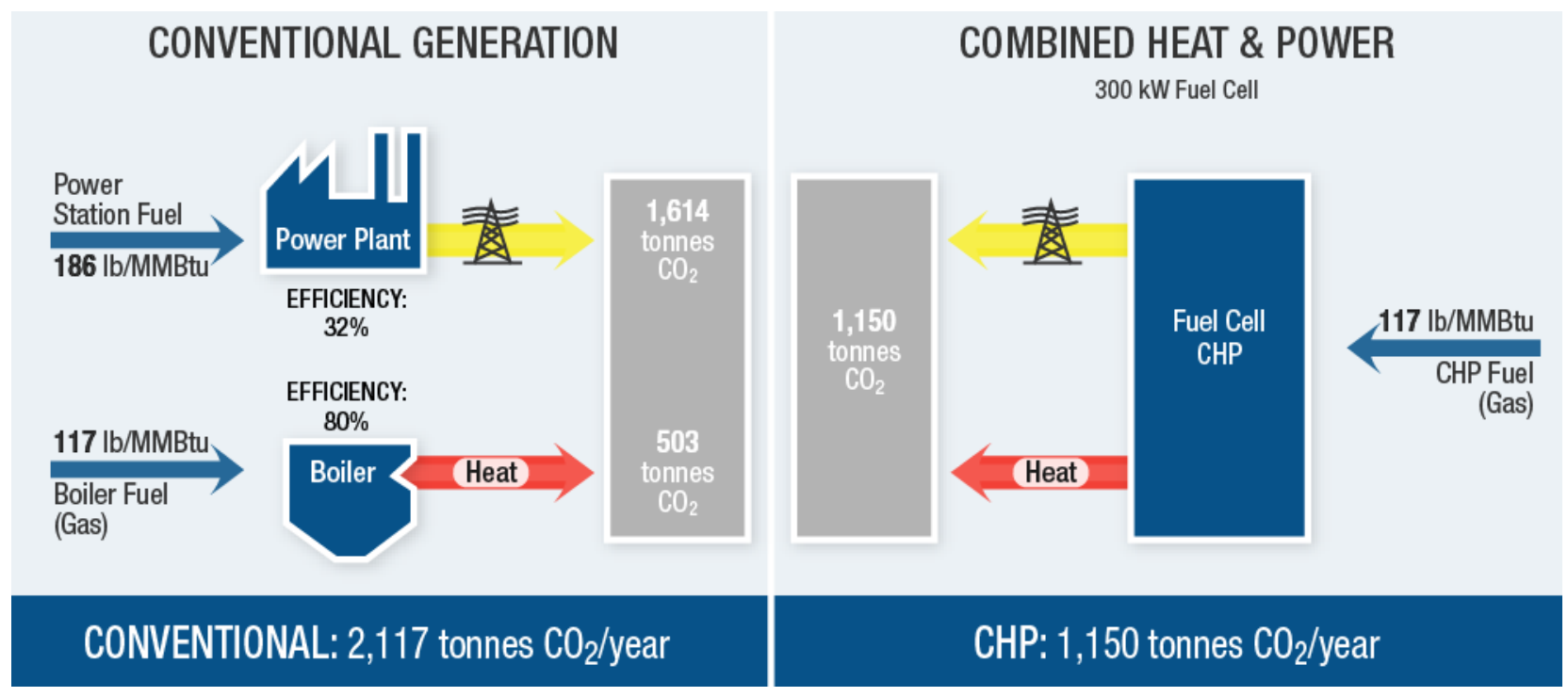

Figure 4. Greenhouse gas emissions savings from fuel cell CHP versus conventional production

The U.S. Environmental Protection Agency (EPA) maintains a Web site that lists GHG emission factors for electricity from different regions in the United States.* EPA's eGRID is a comprehensive source of data on the environmental characteristics of almost all electric power generated in the United States. These environmental characteristics include the following: air emissions for $\mathrm{NO}_{\mathrm{x}}, \mathrm{SO}_{2}, \mathrm{CO}_{2}$, and methane; emissions rates; net generation; resource mix; and many other attributes. The GHG emissions vary with the mix of fuels utilities use to generate electricity.
One useful tool for calculating emission benefits is the EPA CHP Emissions Calculator.** This is a Microsoft ${ }^{\mathbb{E}}$ Excel spreadsheet that calculates $\mathrm{CO}_{2}, \mathrm{SO}_{2}$ and $\mathrm{NO}_{\mathrm{X}}$ emissions from a CHP system and those from a separate heat and power system.

In addition to electricity, fuel cell CHP systems generate useful thermal energy that replaces the production of on-site boilers or water heaters. In most cases, the on-site boiler or water heater will use the same fuel as the fuel cell CHP system. The emissions benefit of fuel cell CHP technology is incremental and largely related to increased efficiency.

\section{Efficiency Benefits}

Figure 5 compares the efficiency of an example fuel cell CHP system with conventional separate production of electricity and useful thermal heat.*** Fuel cell CHP systems can be up to $90 \%$ more energy efficient than conventional generation. In this example, the fuel cell CHP system consumes 100 units of fuel to produce 40 to 50 units of electricity and 10 to 50 units

*EPA eGRID website: http://www.epa.gov/egrid. The regional GHG emission factors are listed in: http://www.epa.gov/cleanenergy/documents/egridzips/eGRID2010V1_1_year07_SummaryTables.pdf (accessed July 20, 2011)

** EPA CHP Emissions Calculator www.epa.gov/chp/basic/calculator.html (accessed July 12, 2010)

*** U.S. DOE. Fuel Cell Technologies Record \#11006. "Fuel Cells for Combined Heat \& Power - CO2 and NOx Emissions." July 2011. 
of hot water, resulting in a $60 \%$ to $90 \%$ overall efficiency. Conventional generation would consume about 125 units of energy at the power plant plus about 44 units of energy at the boiler to meet the on-site energy needs, resulting in an overall efficiency of $40 \%$ to $50 \%$.

\section{Infrastructure Resilience}

Fuel cell CHP systems operating as baseload energy supply increases the resilience of critical systems during extended grid disruptions.

On-site energy production of a fuel cell CHP system increases the ability to maintain operations and recover from natural disasters and power grid outages.

Another advantage is that a fuel cell CHP system operates efficiently as a primary energy source rather than an occasionally used, less efficient backup power supply. Operating as a primary energy source avoids the added capital cost of backup generators.

\section{Opportunity Fuels}

Much of this guide is written from the prospective of using natural gas as a fuel source for the CHP system. Some facilities may have the opportunity to use renewable fuels that can further reduce costs and emissions relative to natural-gas-powered systems. Examples of renewable fuels include biogas from wastewater treatment facilities and methane collected from landfill operations.

Some states recognize fuel cells using natural gas as renewable energy generators. Using renewable fuels can realize additional financial and sustainability benefits.

\section{Requirements for Federal Facilities}

Fuel cell CHP systems have many potential benefits at federal facilities. One is helping federal agencies meet energy management goals. This section describes legislation policies that may be of interest to federal agencies considering fuel cell technology.

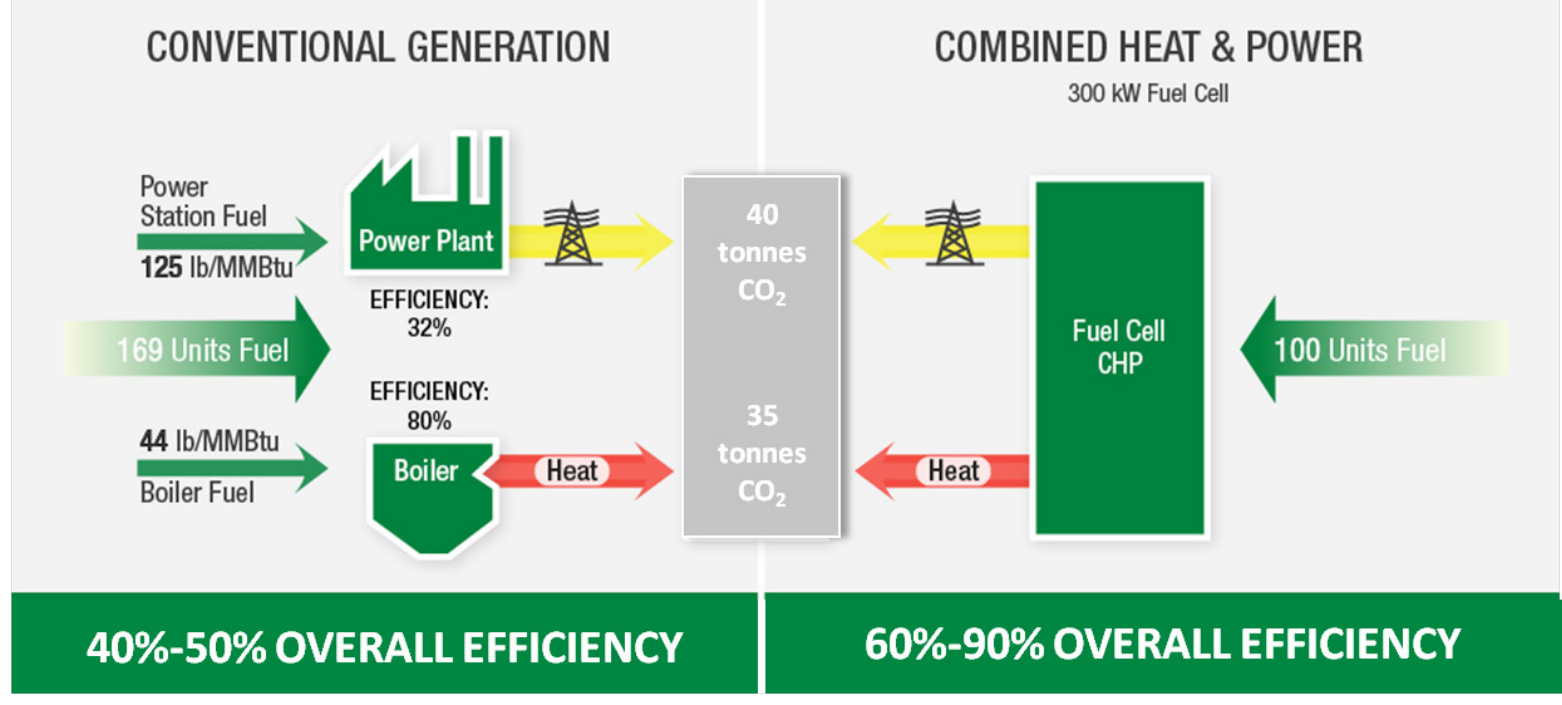

Figure 5. Conventional generation vs. fuel cell CHP efficiency 


\section{Executive Order 13423}

CHP systems may help Federal facilities meet the following energy management goals outlined in Executive Order 13423:

- Agencies shall reduce energy consumption per gross square foot by $3 \%$ annually through the end of fiscal year 2015 or $30 \%$ by the end of FY 2015 relative to the fiscal year 2003 baseline.

- At least half of the statutorily required renewable energy consumed by Federal agencies in a fiscal year must come from new renewable sources in service after January 1, 1999.

Executive Order 13423 also outlines the process for providing credit toward energy efficiency goals from cost-effective projects:

- The Federal Government shall strive to reduce total energy use and associated GHGs and other air emissions as measured at the source.

- Agencies shall undertake life-cycle costeffective projects in which source energy decreases, even if site energy use increases.

- In such cases, agencies will receive credit toward energy reduction goals through guidelines developed by DOE.

This guidance applies directly to the use of CHP systems where on-site energy use may increase, but overall efficiency increases as fuel cell production displaces grid power.

\section{Executive Order 13514}

Executive Order 13514, "Federal Leadership in Environmental, Energy, and Economic Performance," was signed in October 2009. This executive order states that the "Federal Government can and should lead by example when it comes to creating innovative ways to reduce GHG emissions, increase energy efficiency, conserve water, reduce waste, and use environmentally responsible products and technologies."

Federal agencies are directed to use GHG reductions as the primary metric to integrate "sustainability" and budget planning. By January 4, 2010, agencies were required to submit reduction target goals for GHGs by FY 2020, relative to "baseline" of FY 2008. Activities that agencies are expected to consider include the following:

- Reduction of energy intensity in agency buildings (which can be achieved with fuel cell CHP technology)

- Increase agency use of renewable energy (which can include renewable fuels for a fuel cell)

- Reduction of fossil fuel use by reducing agency fleet size and using alternative fuel vehicles and low-GHG-emitting vehicles (including the use of fuel cell powertrains)

\section{Requirement Information}

DOE Office of Energy Efficiency and Renewable Energy (EERE) Web sites offer a wealth of information about the various requirements. See, for example, the following:

Federal requirements are listed at www. eere.energy.gov/femp/technologies/ renewable_requirements.html

FEMP training courses for federal renewable energy goals can be found at www.eere. energy.gov/femp/technologies/renewable training.html

Additional resources are available at www1 eere.energy.gov/hydrogenandfuelcells

Guidance on federal facility reporting requirements is available at www.eere. energy.gov/femp/regulations/facility_ requirements.html 
By June 2, 2010, agencies were required to submit Strategic Sustainability Performance Plans to the Office of Management and Budget and the Council on Environmental Quality in concert with their FY 2012 budgets.

\section{Agency-wide Planning}

Sometimes the motivation for pursuing a fuel cell CHP project may extend beyond the specifics of an individual project in order to be part of a larger effort and pursuit of broader policy goals. A fuel cell CHP project may demonstrate leadership at the site, department, or agency. Implementation of innovative fuel cell technology may represent an agency priority. The following are top-down agency objectives supported by fuel cell projects:

- Compliance with renewable portfolio standards (RPS)

- Reduction of air pollution emissions or GHG footprint on an agency-wide basis

- Compliance with general environmental or efficiency goals through general department pursuits or mandatory compliance

- Enhanced program visibility, with implementation of innovative fuel cell technology at one site raising the profile of the entire agency

- Continued leadership by the federal government in the commercialization of clean energy technology
Whether mandatory or voluntary, these drivers are characterized less by the project numbers, and more by what it means to the organization to do the project at all. In those cases, it is not imperative that the project's direct benefits are meticulously measured, verified, and tied back to the budget.

\section{GHG Inventory Issues}

Federal agencies are required to inventory their GHG emissions. These emissions are categorized as Scope 1 (on-site emissions), Scope 2 (emissions related to purchased energy) and Scope 3 (emissions associated with other procurements and waste disposal). Fuel cell CHP projects will have implications for these inventories, which should be considered carefully.

Fuel cell CHP projects using natural gas or other fossil fuels will generate on-site GHG emissions that are Scope 1. Typically, the electricity produced by the fuel cell will displace purchased electricity, which is Scope 2. Because fuel cells are highly efficient, they can achieve significant reductions in Scope 2 emissions.

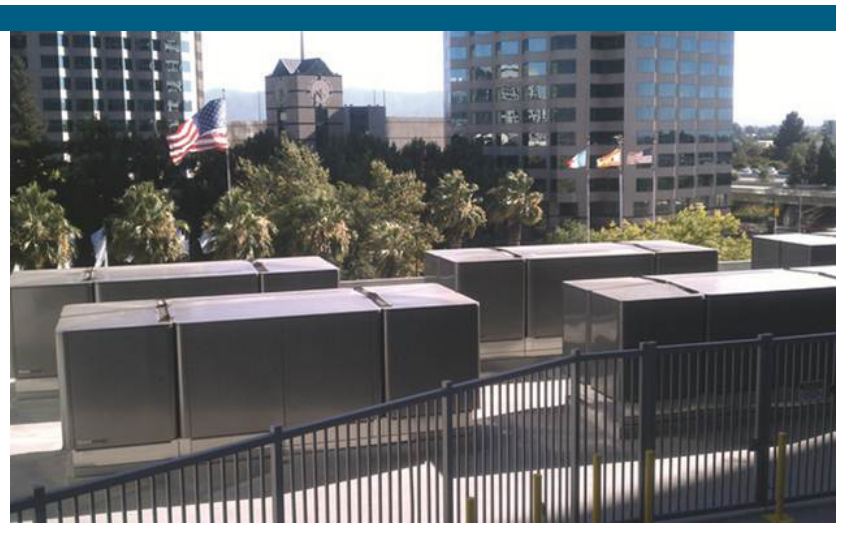

1.2 MW Bloom Fuel Cell Installation at Adobe Headquarters in San Jose, California Adobe expects to reduce its carbon footprint by approximately 121.5 million pounds over the next 10 years

"Installing Bloom Energy fuel cells supports Adobe's efforts to remain at the forefront of utilizing impactful, clean technologies

to reduce our environmental footprint. We hope to be an example to other companies considering cleaner, more affordable energy sources for their operations." -Randall H. Knox, Senior Director Global Workplace Solutions 


\section{Screening for Fuel Cell CHP at a Facility}

Fuel cell CHP systems can deliver superior technical and financial performance, if the conditions are right. Before investing significant resources in a fuel cell CHP effort, however, facility managers are encouraged to consider available incentives, local spark spread, and the viability of fuel cells for meeting their energy needs. Clearing these three hurdles is essential to achieving a successful fuel cell CHP project.

Fuel cell CHP systems must be fully integrated at a facility to realize their potential benefits, and sufficient time and effort should be allotted when deciding to install a fuel cell CHP system. This chapter includes a simplified decision tree (Figure 6) that agencies can use to decide whether a site is a good candidate for fuel cell CHP technology. Many facilities will not be well suited because of technical considerations, an unfavorable spark spread (the difference between natural gas and electricity prices), or insufficient financial incentives. For facilities that pass this screening process, the next step is to perform a simplified cost analysis. Appendix B contains information on cost screening for projects, including resources for facility managers.

\section{Is the Facility a Good Match for Fuel Cell CHP?}

The first decision point in the screening process is assessing whether fuel cell CHP technology is an appropriate technology for the facility in question. The best match is a facility with large, stable electric and thermal loads and a need for the performance characteristics (e.g., emissions, reliability) that fuel cell CHP systems can deliver.

Information on the facility's electrical and thermal energy demand can be obtained by analyzing recent utility bills or directly from on-site meters. In particular, it is important to identify the size of the electrical load and thermal loads expected to be served by the fuel cell CHP. Good candidate sites will generally have the following characteristics:

- Average electric load is $100 \mathrm{~kW}$ or higher

- Ratio of average electric load to peak load is $>0.7$

- Have central, chilled water plants and/or constant cooling needs

\section{At-a-Glance}

Details on what's included in this section:

1. Is the Facility a Good Match for CHP?

2. Spark Spread

3. Incentives

4. Renewable Energy Credits 


\section{Decision Tree for Fuel Cell CHP}

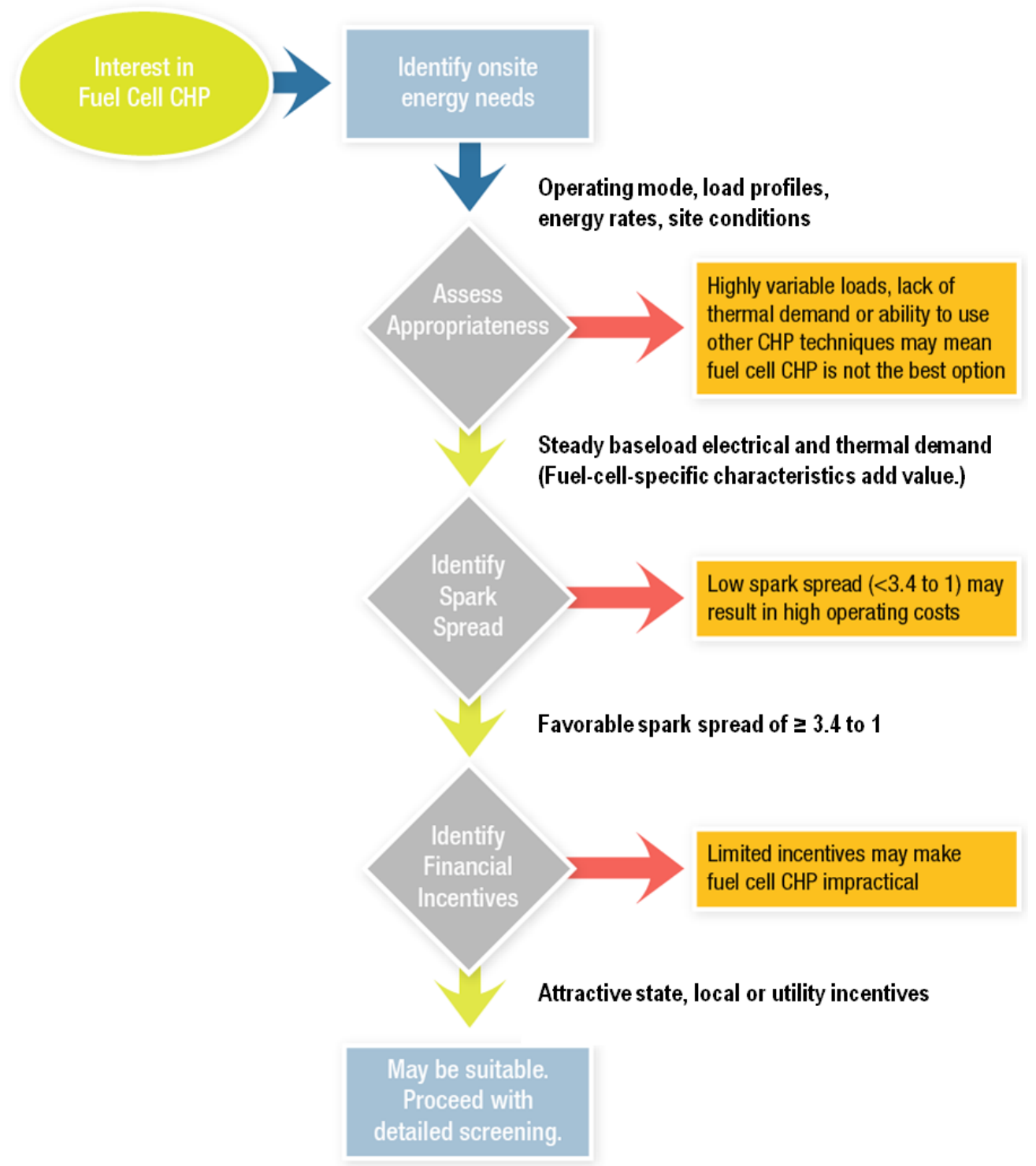

Figure 6: Decision tree for fuel cell CHP
- Have a thermal load that must be met on a continuous basis (Examples include a central or district heating system or hot water for a medical facility.)

- Thermal demand is matched to electric load on a daily and seasonal basis

- Operate more than $>6,000$ hours per year

In addition to this quantitative information, facility managers should think about whether there are other conditions that would favor a fuel cell CHP system. As noted in the previous chapter, fuel cells have advantages over other CHP technologies and the electricity grid; however, fuel cells tend to be more expensive than other options. The relatively high up-front costs can be defined, though the lifecycle costs of a fuel cell are not always more than other options.

Factors that could make a fuel cell CHP system the preferred option include strict air pollution limits, GHG emissions objectives, noise sensitivities, space availability (limited footprint), and the need for reliable power for critical systems.

\section{Spark Spread}

The ratio of the local electricity price to the price of fuel is known as the "spark spread." This ratio is the most direct means of screening whether a CHP project can be financially viable in a particular location. Historically, a spark 
spread of 3.4 or higher has been considered the level where CHP becomes competitive with electricity from the grid.

Figure 7 shows the spark spreads for each state based on the average price of electricity and natural gas for commercial customers. In 2007, there were only 4 states with a spark spread of
3.4 or higher; by 2010, however, there were 16 states with this favorable spark spread due to a significant decrease in the price of natural gas. In fact, increased domestic production of natural gas resulted in more favorable spark spreads in nearly all states. Facility managers are advised to check with their local utilities to obtain actual electricity and fuel prices for their facility.

\section{Incentives}

Realizing the benefits of federal and state financial incentives is essential to maximizing the financial benefits of fuel cell CHP projects. Most projects may not be viable without substantial financial support from state, local, and/or utility fuel cell

\section{Spark Spread}

Commercial Sector Ratio of Electricity to Natural Gas

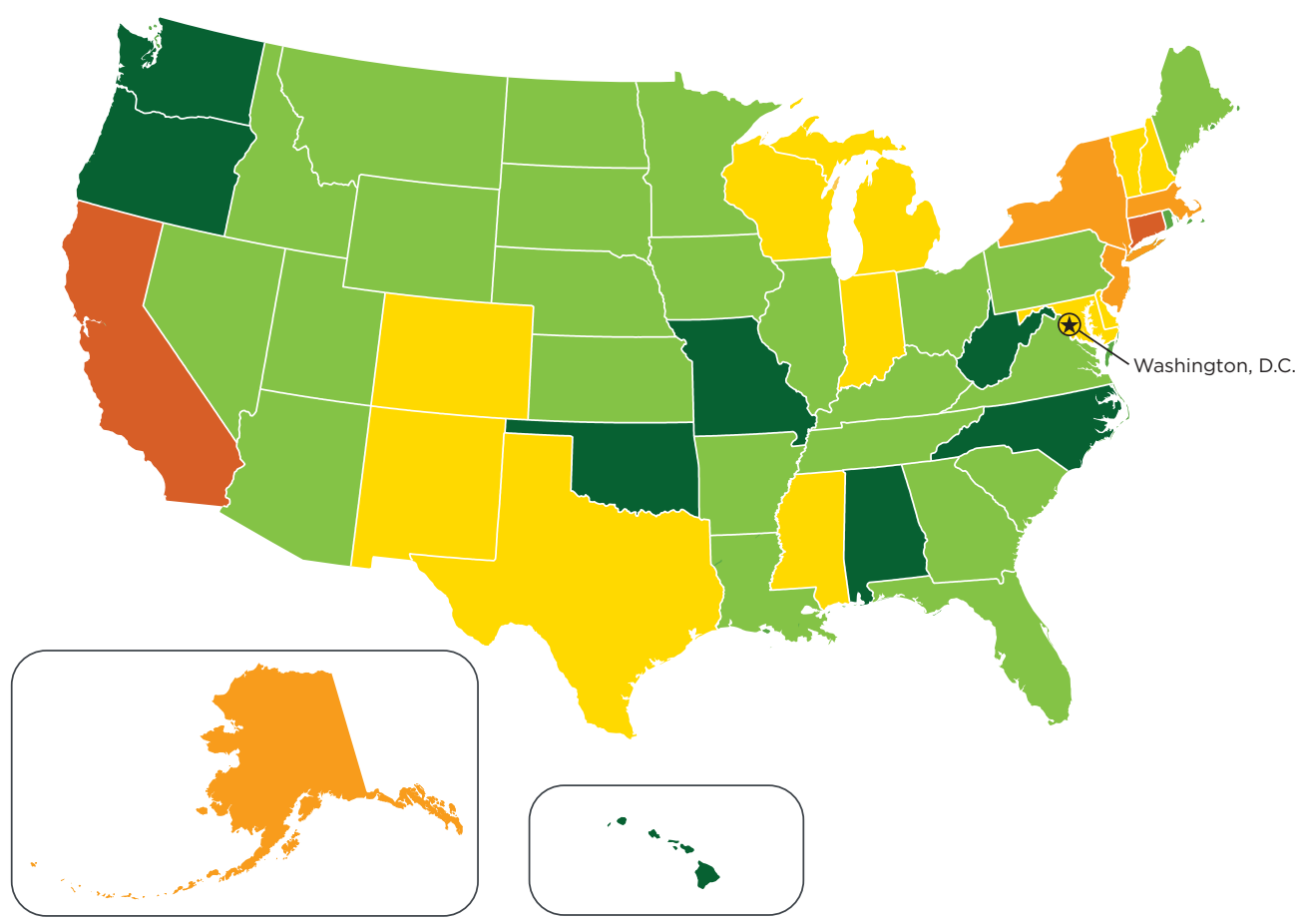

\section{Legend}

Less than 1.8

1.8 to $<2.4$

2.4 to $<3.4$

3.4 to $<4$

4 to $<5$

$>5$

Reference: DOE Energy Information Administration, Electric Power Monthly Table 5.6B, Natural Gas Monthly, ng_pri_sum_a_epgO_pcs_dmcf_a.xls

Figure 7: Spark Spread Maps for 2010. Spark Spread = ratio of electricity prices to natural gas prices 
FEMP

Energy Incentives Map

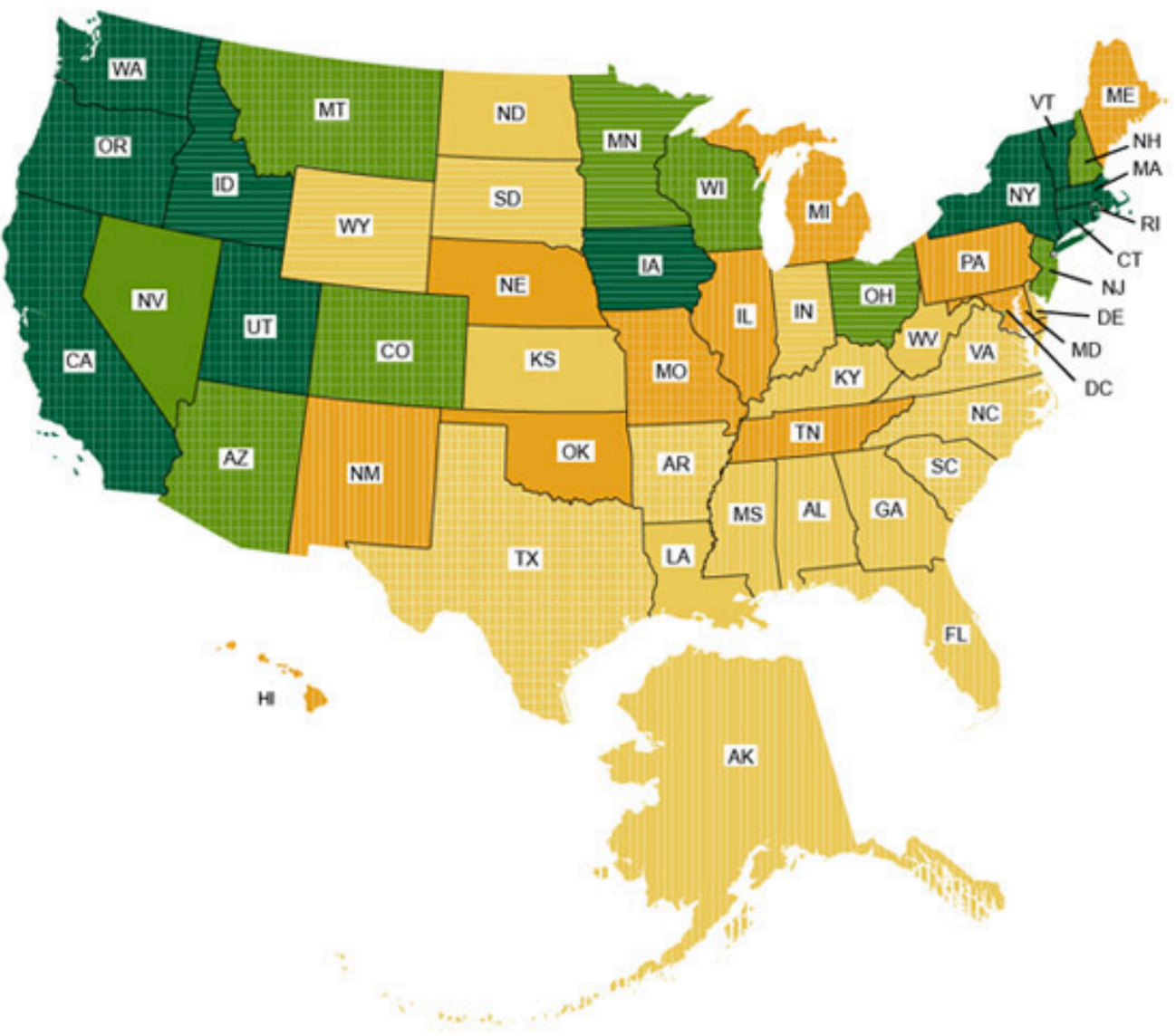

Legend

These states budgeted over $2 \%$ of electric revenues for electric energy efficiency programs in 2010

These states budgeted between $1 \%$ and $2 \%$ of electric revenues for electric energy efficiency programs in 2010

These states budgeted between $0.5 \%$ and $1 \%$ of electric revenues for electric energy efficiency programs in 2010

These states budgeted less than $0.5 \%$ of electric revenues for electric energy efficiency programs in 2010 or did not provide data

I| These states have distributed generation (including renewables) programs available

$\equiv$ These states have gas programs

Figure 8. FEMP Energy Incentives Map.

* See http://www.eere.energy.gov/femp/financing/energyincentiveprograms.html incentive programs. Because incentives may be available for up to $50 \%$ of the capital costs of a system, a thorough screening process should include understanding federal requirements and the agency's policies on incentives.

Most states have energy incentive programs that help offset capital equipment costs and promote innovative and renewable energy technologies, including fuel cells. Financial incentives for CHP systems are available in the form of direct financial grants, tax incentives, low-interest loans, or utility and environmental policies that increase the financial prospects for a project.

In many cases, the federal government is ineligible for many of these incentives. Private developers, however, can take advantage of the tax credits, grants, and other incentives that encourage fuel cell and renewable technologies. Understanding the ability of federal/private parties to take advantage of these incentives is a key consideration in deciding whether to fund the project through direct appropriations or alternative financing.

DOE Federal Energy Management Program (FEMP) staff members research these programs on a state-by-state basis to help federal agencies meet their energy management goals.* This information can aid in determining which incentives apply to an agency's specific circumstances and help estimate any economic impact on the project. It is also critical to consider the time limitations on the incentives and to confirm that they will still be offered 
when the project applies to receive them. Figure 8 is FEMP's Energy Incentives Map, which highlights the states spending the most on energy efficiency.

There are additional sources of information on incentives that may be available to particular projects. The Database of State Incentives for Renewable Energy (DSIRE)* is one of the best sources for incentives information for a particular site. A summary and details for incentive programs can be accessed by state, and information on federal incentives is available as well.

Fuel Cells 2000 (a non-profit [501(c)(3)] independent, educational organization) is another group that compiles incentives offered by states. Fuel Cell 2000's recent report, "State of the States: Fuel Cells in America 2011," is available at at the DOE Fuel Cell Technologies Program Web site.** Figure 9 shows the states that have an RPS or offer a tax incentive for fuel cell systems, according to Fuel Cells 2000.

The variety of incentives and the changing landscape of state government finances limits the usefulness of a single snapshot of incentives. It is essential that each project be evaluated based on the state in which it is located.

Most states have some incentives or programs to encourage the installation of fuel cell technology in addition to those offered by the federal government. Eleven states have

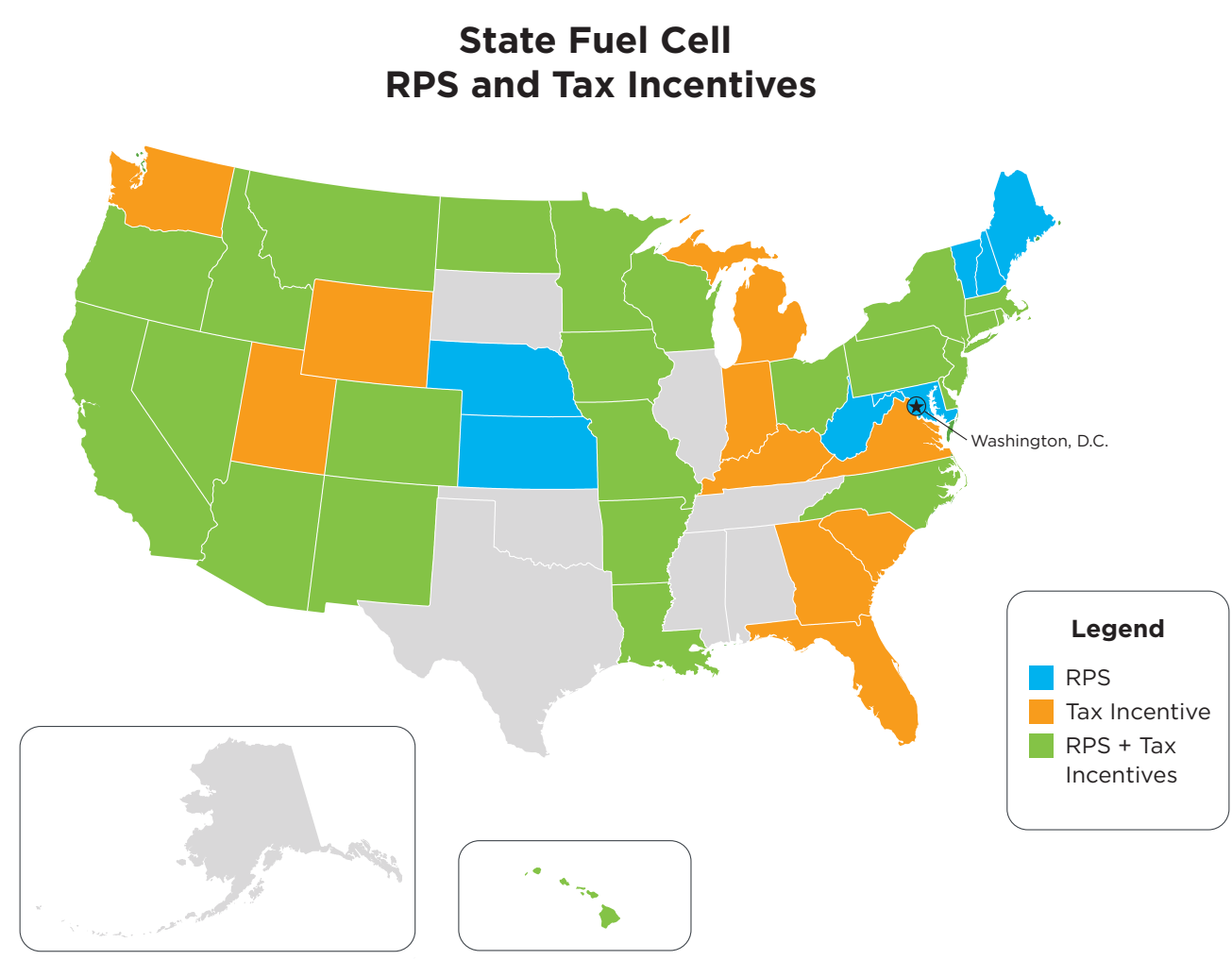

Figure 9. State RPS and Tax Incentives***

* A Database of State Incentives for Renewable Energy (DSIRE) http://www.dsireusa.org

** http://www1.eere.energy.gov/hydrogenandfuelcells/pdfs/stateofthestates2011.pdf

*** State of the States: Fuel Cell in America. 2010. Fuel cells.org. http://www.fuelcells.org/StateoftheState.pdf. 
Incentive programs for fuel cells change frequently. Below are 11 states with strong incentives available in early 2011 (accessed from www. DSIREusa.org on June 12, 2011 and www.fuelcells.org on July 13, 2011). This listing is intended to be a snapshot, but not definitive, because incentives are added, updated, and terminated frequently. It is recommended that interested agencies contact the relevant administrating agency or utility.

- California: Self-Generation Incentive Program (SGIP) offers substantial grants. California is proposing $\$ 2,250 / \mathrm{kW}$ caps, with portions of the funding being performance-based. Additional incentives include feed-in tariffs for fuel cells using renewable fuels.

- Connecticut: The Clean Energy Finance and Investment Authority (CEFIA), formerly the Connecticut Clean Energy Fund (CCEF), offers substantial grants $(\$ 2,500 / \mathrm{kW})$. The Renewable Portfolio Standard (RPS) includes fuel cells, along with wind and solar. The state is moving to a performance-based system $(\phi / \mathrm{kWh})$ in 2012.

- Delaware: Delaware R\&D grants offer $35 \%$ of the cost of qualifying projects up to $\$ 250,000$. The state also offers technology and demonstration grants of $25 \%$ of the cost of qualifying projects up to $\$ 200,000$. The Green Energy Fund's Technology Demonstration Program includes fuel cells. Delaware has interconnection standards, net metering, and an RPS that includes fuel cells.

- Florida: The state's Qualified Target Industry Program provides tax refunds for companies that create high wage jobs, including fuel cells. Florida also launched H2 Florida, which aims to accelerate the commercialization of hydrogen technologies.

- Massachusetts: The Green Building Tax Credit includes fuel cells. A system benefits charge goes to the Renewable Energy Trust Fund, which can offer grants or loans for fuel cell projects. The state also has a number of initiatives, including interconnection standards, net metering, and a renewable portfolio standard.

- Hawaii: Hawaii has implemented a \$10 million hydrogen investment capital special fund through the Hawaii Renewable Hydrogen Program. The state also has interconnection standards and net metering for fuel cells.
- Minnesota: The Xcel Energy Renewable Development Fund Grants and State Alternative Fuel and Technology Grants can go to fuel cells using renewable fuels. These programs focus on the use of biomass, methane, and other farm-produced anaerobic digester gas in fuel cells.

- New York: The New York State Energy Research and Development Agency (NYSERDA) offers programs providing capital investments $(+\$ 1,000 / \mathrm{kW})$ and production incentives $(\$ 0.15 / \mathrm{kWh})$. Grants are capped at $\$ 1$ million per project.

- Ohio: The state's Alternative Energy Resource Standard is a portfolio standard that requires utilities to buy renewable electricity, which include fuel cell generation. Fuel cells qualify for a property tax exemption and net metering. The Ohio Job Stimulus Plan (Advanced Energy Program) includes a $\$ 150$ million fund for advanced technologies such as fuel cells. Ohio's Fuel Cell Roadmap, Third Frontier Program, and Fuel Cell Initiative are part of a broad effort to develop a strong fuel cell manufacturing base and related supply chain.

- South Carolina: Fuel cells are exempt from the state sales tax. South Carolina's "hydrogen highway" opened in 2009, located between Aiken and Columbia. The South Carolina Hydrogen and Fuel Cell Alliance reports $65 \%$ job growth in its hydrogen cluster since 2004 . The state has multiple programs to encourage fuel cell $\mathrm{R} \& \mathrm{D}$, including the University of South Carolina's new Solid Oxide Fuel Cell Program.

- Texas: The Texas Hydrogen Roadmap is helping to increase hydrogen production and demand, although much of this is focused on transport applications. The Houston Advanced Research Center includes fuel cell R\&D. 
particularly strong incentives, making them the best candidates for financially viable projects.

Projects in other states may be more difffult to successfully execute.

\section{Renewable Energy Credits}

In some states, the output of a fuel cell is eligible for renewable energy credits (RECs) when using natural gas. In other states, RECs are issued only if the fuel cell uses a renewable energy source such as biogas. RECs are the property right attribute created when electricity is generated by a renewable energy source. The RECs can be sold to a utility to help meet its renewable portfolio standard (RPS) needs, sold on the voluntary market, or "retired" and counted by the agency toward its mandated renewable energy requirements.

Project developers often sell the RECs as part of the project financing package. If the RECs have been sold, they are not available to help the agency meet its renewable energy requirements, although it may not affect compliance with executive orders.

An agency might also have a policy on accepting certain incentives. Several agencies are evaluating whether accepting financial incentives from limited financial pools reduces the incentives available to privatesector investment. If this is the case, agencies may establish policies prohibiting the use of available renewable energy and energy efficiency incentives in projects.

Because of the high capital costs of fuel cell CHP systems, maximum utilization of all financial incentives is necessary to increase the chances that a project will be financially viable. In the absence of sufficient incentives the project economics must rely more heavily on the difference in price between the cost of electricity and the cost of gas.

\section{BIOGAS}

Depending on the location of your facility, renewable biogas can be considered either as an alternative source of energy or as a supplement to natural gas as the fuel for a primary power fuel cell. Several businesses and municipal facilities already use fuel cells to make electricity and heat from biogas, which can be sourced back to landfills or wastewater treatment plants.

Fuel cells operating on biogas offer a pathway to renewable electricity generation. With federal incentives of either $\$ 3,500 / \mathrm{kW}$ or $30 \%$ of the project costs (whichever is lower) and the California Self Generation Incentive Program, which provides $\$ 4,500 / \mathrm{kW}$ for fuel cell using renewable feedstock, businesses and municipalities can achieve a reasonable payback period of less than five years while reducing $\mathrm{GHG}$ emissions and proving green energy and fuel.

\section{CASE STUDY}

The City of Tulare, California, has installed four $300 \mathrm{~kW}$ biogas fuel cells that use biogas from wastewater treatment operations. The system uses approximately 500,000 cubic feet of biogas per day, displacing consumption of fossil fuels, such as natural gas. The biogas is produced by the anaerobic digestion of industrial wastewater from cheese and ice cream production plants. The $1.2 \mathrm{MW}$ fuel cell project is one of the largest biogas fuel cell installations using biogas from a wastewater treatment plant. This fuel cell CHP system generates $40 \%$ fewer GHGs than grid electricity and has $97 \%$ availability. The City of Tulare expects a return on its investment in less than five years. 


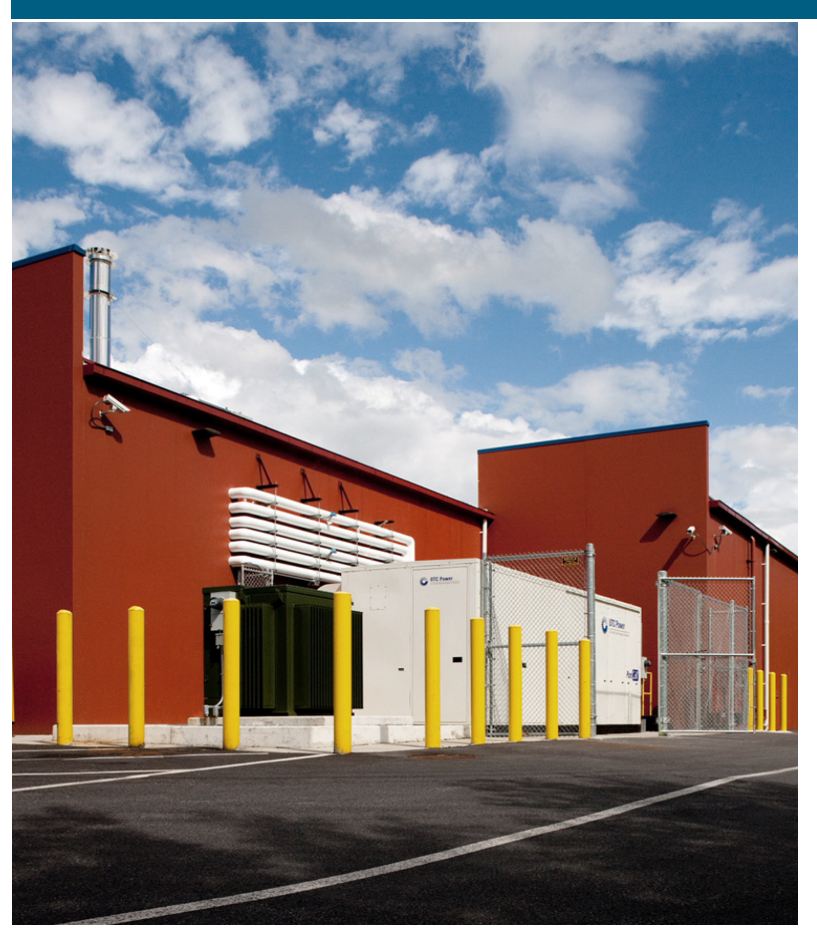

A $400 \mathrm{kw}$ PAFC at a Price Chopper store in Colonie, New York.

A $400 \mathrm{~kW}$ fuel cell (grey box) meets 85 percent of the energy needs of this Price Chopper supermarket in Albany, New York. The installation reduces the building's carbon footprint by 71 tons, provides energy security for perishable items, and saves more than 4 million gallons of water each year.

Photo courtesy of UTC Power

\section{DOE'S CLEAN ENERGY APPLICATION CENTERS}

DOE's Clean Energy Application Centers promote CHP, waste heat recovery, and other clean energy technologies and practices, and they offer regional assistance for specific projects throughout the United States. The centers were formerly called the Combined Heat and Power (CHP) Regional Application Centers (RACs). There are nine Clean Energy Application Centers that provide market assessments, targeted education, and outreach and expert technical assistance to the CHP community, including federal facilities.

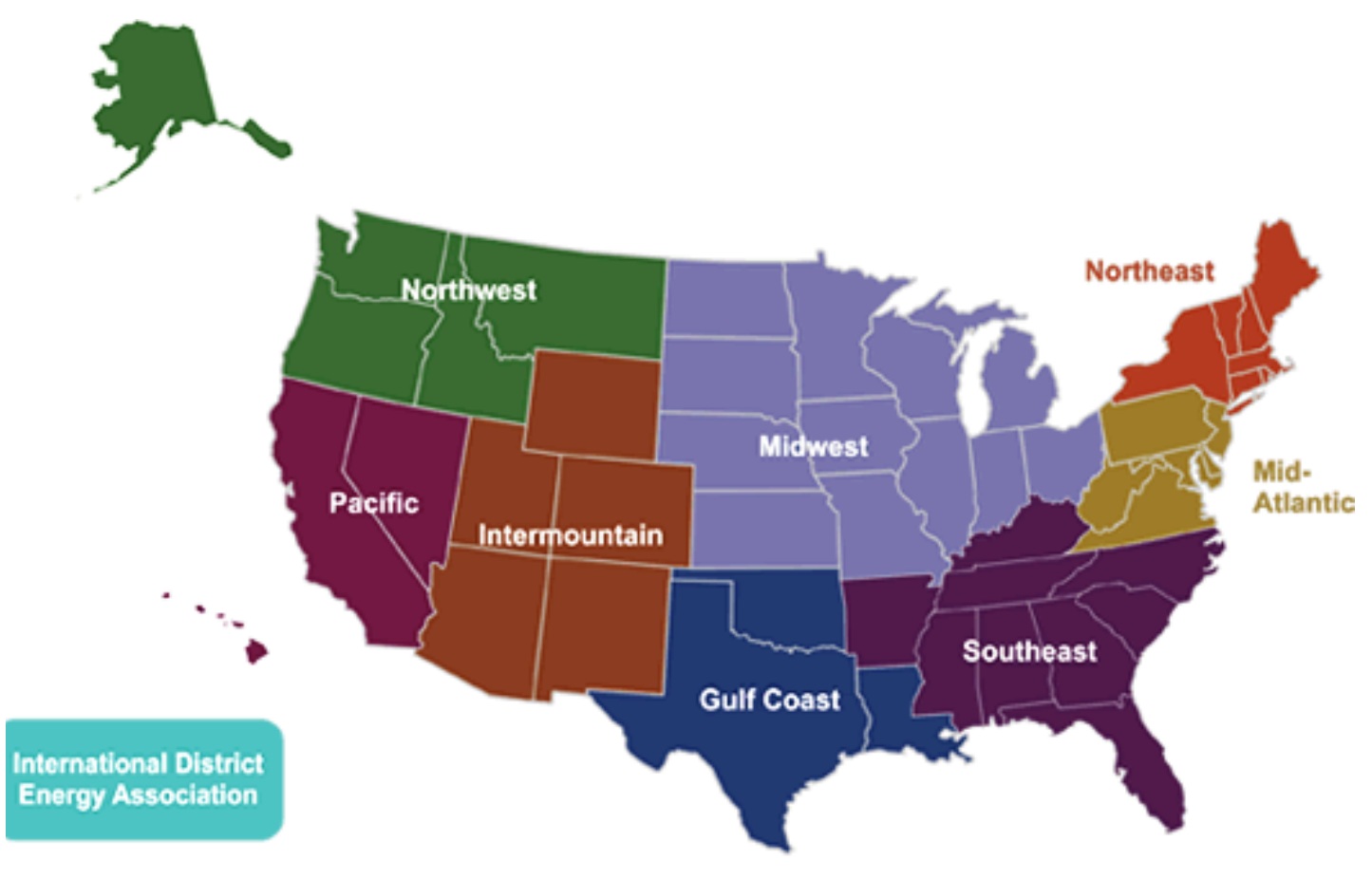

Figure 10. DOE Clean Energy RACs*

* See the DOE Clean Energy Application Centers website: http://www1.eere.energy.gov/industry/distributedenergy/racs.html 


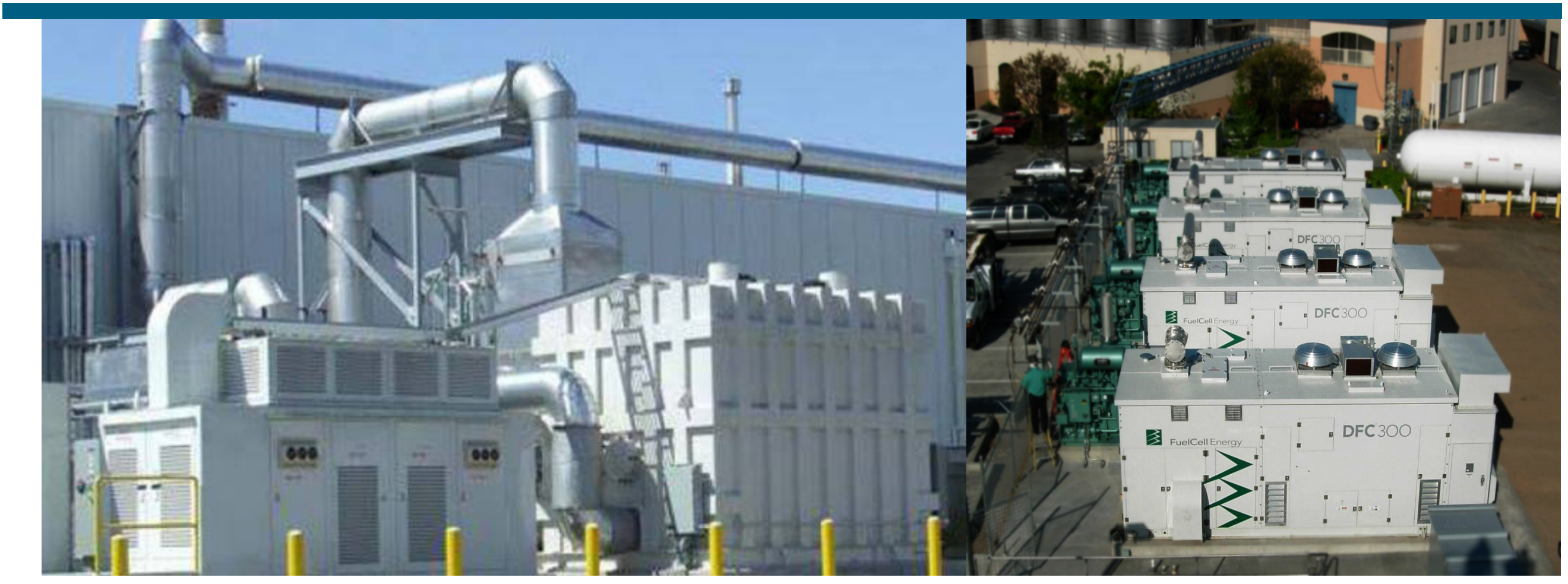

300 kW units: Molten Carbonate Fuel Cell (MCFC), FuelCell Energy, Inc; Fuel Cells Provide Primary Power

\section{Detailed Planning for a Fuel Cell CHP Project}

The decision to implement a fuel cell CHP program may be the result of top-down agency guidance to pursue this technology or from specific site needs and goals. This section walks through the steps needed to execute a fuel cell CHP procurement and is intended to help those charged with carrying out the project. This section is written from the perspective of implementing a single system, although agencies should look for innovative ways to aggregate procurements as much as possible to benefit from economies of scale and to reduce transaction costs.
At-a-Glance

Details on what's included in this section:

1. Identify Needs and Goals

2. Assemble an On-Site Team

3. Evaluate Fuel Cell Options

4. Consider Project Requirements and Recommendations 


\section{PLANNING}

\begin{tabular}{|c|c|}
\hline DIRECTION » & STAFFING » \\
\hline $\begin{array}{c}\text { Identify Needs } \\
\text { and Goals }\end{array}$ & $\begin{array}{c}\text { Assemble } \\
\text { an On-site } \\
\text { Team }\end{array}$ \\
\hline
\end{tabular}

Common Reasons for Considering a Fuel Cell Project

- The agency must meet renewable energy and energy efficiency targets.

- The appropriations are available for improving a facility.

- The project is a good way to meet a site's energy needs.

- The project can provide energy cost savings.

- The project can reduce future energy cost volatility and uncertainty.

- The project will earn credits toward LEED certification.

\section{Potential Goals or Criteria}

- Maximize on-site fuel cell energy production

- Maximize the return on investment

- Design fuel cell CHP system to provide all energy for critical function
Initial Team Members

- Fuel cell project manager

- Contracting officer

- Energy manager

- Environmental expert

- Facility manager

- Site managers

- Fuel cell technology expert

- Utility point of contact

\section{Additional}

Team Members

- Attorney or general counsel (e.g., for contract and authority issues)

- Budget officer

- Facility master planner

- Real estate officer

- Safety officer

- Sustainability officer

SITE EVALUATION »

CONSIDERATIONS »

\section{Consider Project}

Requirements and

Recommendations

\section{Options}

Run FC Power Model

Project Fuel Cell Screening

- Manufacturer's warranty

- Available square footage

- Estimate of the system's size

- Historic building issues

- Incentives (federal, state, local, utility, RECs)

- Siting and site access

\section{Project Fuel Cell Feasibility}

- Capacity of the local industry to supply and maintain system

- Utility interconnection issues

- Electrical/mechanical room issues

- Size, condition, and efficiency of existing heating systems.

\section{Considerations}

- Utility interaction

- Indemnity

- NEPA compliance

- Air Permit

- Controls and Communications

- Buy American Act provision 


\section{Step 1. Identify Needs and Goals}

There are several common reasons for agencies to consider a fuel cell CHP project:

- The agency must meet renewable energy and energy efficiency targets.

Fuel cell CHP using renewable fuels can help meet Executive Order and EPAct requirements.

- The appropriations are available for improving a facility.

In some cases, funds have been designated for the outright purchase of a fuel cell project. More commonly, fuel cell projects are financed by private investors.

- The project is a good way to meet a site's energy needs.

Fuel cell CHP can provide reliable, on-site power within limited building footprints and with less noise than other options.

- The project can provide energy cost savings.

With appropriate incentives, spark spread and financing vehicles, fuel cell CHP projects can deliver long term cost savings.

- The project can reduce future energy cost volatility and uncertainty.

Adding onsite production with a fuel cell provides an additional option for meeting a site's energy needs. This can allow facility managers to manage risk and savings by taking advantage of purchased fuel (i.e., natural gas), renewable fuel (i.e., biogas), and purchased electricity prices.

- The project will earn credits toward Leadership in Energy and Environmental Design (LEED) certification.

Fuel cell CHP using renewable fuels may help a facility achieve its desired LEED certification.

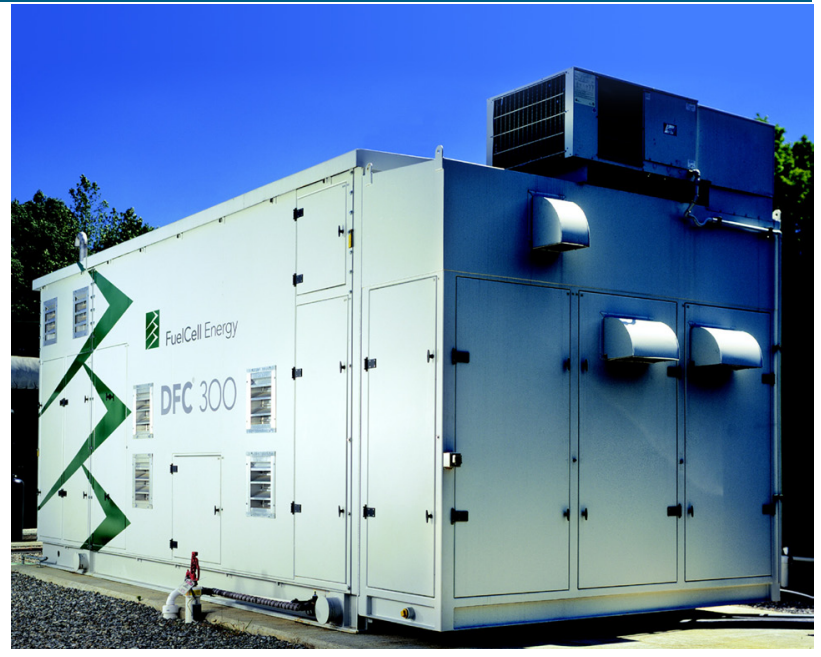

The reasons for considering a fuel cell CHP project help to define the needs and goals that the project will address. Needs and goals comprise the vision and principles that guide the process of setting priorities, creating decision criteria, and making decisions. On-site energy production is a major organizational and financial commitment and should be part of a broader vision of whole systems design for buildings and sites. Potential goals or criteria include the following:

- Maximize on-site fuel cell energy production

- Maximize the return on investment

- Design the fuel cell CHP system to provide all of the energy needed to operate a specific critical function

Goals could adjust or change as the project develops, but they always should be at the forefront during the decision-making process. 


\section{Step 2. Assemble an On-Site Team}

At this point, a fuel cell CHP project team should be identified. The team is important not only for getting the work done, but also for making sure that all issues are considered. Even small oversights can be costly in terms of dollars and time, and they can even result in a failure to accomplish project goals.

One of the most important features of the team should be its alignment with the project's goals. Referring to Step 4, "Consider Project Requirements and Recommendations," can help when considering the makeup of the team. That step outlines the diverse considerations that feed into successful project completion. It is important to recognize that it takes a diverse group of people with a wide range of skills to bring a project to fruition.

The initial project team might be small and include only those members relevant to the immediate task; this type of team can grow as the project requires. As an alternative, the team could include - from its inception - everyone who has a stake in the project process. This decision should be based on best judgment and staff availability.

If starting with a small team, the people who should participate, particularly in the Step 3 site screening, include the following:

- Fuel cell project manager

One person must champion the project to overcome the many hurdles to bring a project to completion.

Contracting officer

Fuel cell CHP projects will almost always require a financing mechanism and appropriate personnel should be included early in the process.

Energy manager

The project has major energy procurement and consumption factors that require the participation and support of the energy manager.

- Environmental expert

Although fuel cells have very low emissions, there are permitting requirements that must be met.

In Facility manager

- Site managers (if multiple people are responsible for different parts of the site).

- Fuel cell technology expert (depending on procurement option selected).

Utility point of contact

Even if no power from the fuel cell will be exported to the grid, participation of the utility is necessary to manage interconnection and billing.

As the project progresses, adding other team members should be considered:

- Attorney or general counsel (e.g., for contract and authority issues)

- Budget officer

- Facility master planner

- Real estate officer

- Safety officer

- Sustainability officer 


\section{Operation and Metering}

Operation and metering of a fuel cell CHP project is typically the responsibility of the seller through a service and/or OEM agreement. This includes regular inspection and repair, if necessary, to ensure reliable operation of the CHP system. Table 1 lists example maintenance and repair items. Responsibility for O\&M should be specified in the procurement contract.

Typically, the seller is also responsible for installing and maintaining a meter to determine the quantity of output of electricity that will be sold. Under this circumstance, the seller must also provide real-time data at the request of the buyer, including atmospheric data relevant to the type of renewable technology installed.

Fuel cell CHP systems require maintenance to maintain the safe and reliable performance of the equipment. In addition, all service work on the fuel cells must be provided by trained and manufacturer-certified technicians to keep warranties in effect. Typically, the company installing the equipment will include a warranty on the equipment (e.g., 5-year, all-inclusive warranty) and a maintenance service agreement may be offered.

The conditions and costs related to fuel cell stack replacement must be described in any contract related to the fuel cell CHP system. Stack replacement can be very expensive (as much as half of the cost of the entire system) with possible disruptions to facility operations. It is important that the contract state when the fuel cell stack will be replaced, which is usually a performance measure (such as $10 \%$ degradation of the manufacturer's specified power level). Also the contract should define who must pay for replacing the stack as well as responsibility for timely replacement of the stack and compensation for lost energy production.

Table 1 Examples of Scheduled Maintenance Items

\section{Annually}

Filter cleaning/replacement

Fuel system and wiring replacement

Water quality evaluation

Verify proper operation of control valves

Pressure relief valve visual inspection

Flame sensor

Perform gas analysis

Igniter cleaning and inspection

Heat exchanger cleaning and inspection

Obtain substack voltages

Dust \& corrosion: general cleaning \& inspection

Duct inspections

Freeze protection system inspection

Sensor calibration

Uninterruptible power supply battery replacement
It is recommended that the arrangements are made to perform the maintenance on key fuel cell CHP equipment. These may include extended controls, heat exchanger and pumps. The contractor should provide to the agency all equipment start-up checklists and reports, system test reports, malfunction/deviation reports, diagnostics and repair documentation and other related items at the project site after the project completion. Table 1 below lists system components that should be included in a maintenance program.

\section{Three to Five Years}

Flow orifice replacement

PCS check terminal tightness

Pump replacements

Pressure relief valve replacement

Controller battery replacement

Variable speed drive cooling fan replacement

Drive removal (as needed) 


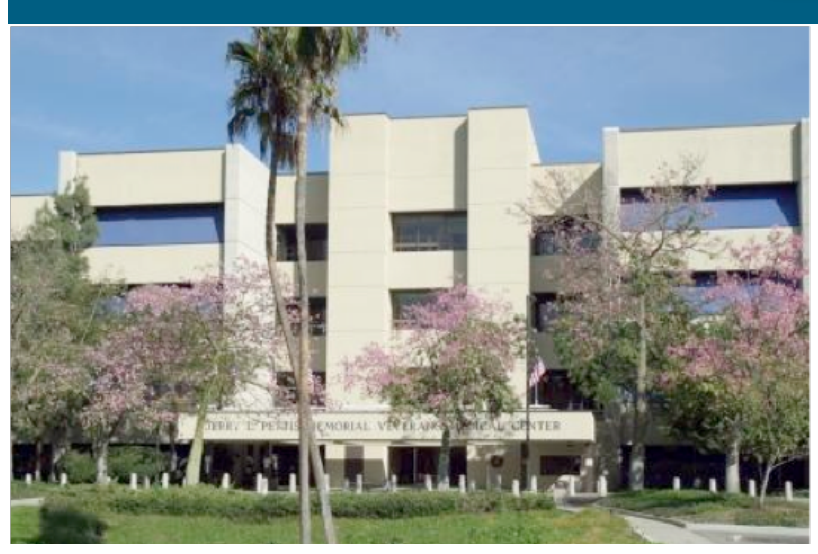

Fuel Cell CHP at the Department of Veterans Affairs: Loma Linda, California

http://www.lomalinda.va.gov/images/LLHCSweb.jpg Agency: Department of Veterans Affairs

\section{Sales}

\section{DELIVERY POINT}

The contract with the developer will determine where the sale of electricity takes place in relation to the location of the buyer and seller. Typically, the delivery point is located on the high-voltage side of the transformer adjacent to the project. In this type of transaction, the buyer is responsible for transmission of the energy from the seller to the facility's equipment. Otherwise, the contract will distinguish another delivery point that was contractually agreed on by both parties.

\section{PRICING}

Electricity rates may be agreed upon for a power procurement contract. Prices may be flat, escalate over time, or be negotiated in any other way as long as both parties agree to negotiated costs. A contract will often specify how much energy the supplier is expected to produce each year. This system is intended to provide an incentive for the seller to accurately estimate the amount of energy that will be produced in a given period of time.

\section{BILLING AND PAYMENTS}

The contract should describe how invoices are prepared and the time period of response to those invoices. This also includes how to handle late payments. The buyer also has the authority to audit those records produced by the supplier in any circumstance.

\section{PERFORMANCE INITIATIVES}

The buyer will typically require the seller to guarantee that the project will meet certain performance standards. Performance guarantees let the buyer plan accordingly when developing new facilities or when trying to meet demand schedules, which also encourages the seller to maintain adequate records. The contract should define the obligations of the seller when the output from the supplier fails to meet the contractual energy demand by the buyer. The contract may include availability guarantees and power-curve guarantees. These two types of guarantees are more applicable in regions where the energy harnessed by the renewable technology is more volatile. 


\section{Step 3. Evaluate Fuel Cell}

\section{Options}

This section outlines the information needed to evaluate options for the fuel cell CHP system. DOE's Fuel Cell Technologies Program has developed the Fuel Cell Power (FCPower) Model.

The FCPower Model can be downloaded from DOE's Fuel Cell Technologies Web site.* FCPower is a financial tool for analyzing hightemperature, fuel-cell-based CHP generation systems. It uses a discounted cash flow rate of return methodology to determine the cost of delivered energy, and it quantifies energy inputs/outputs and GHG emissions. Currently, the FCPower Model has two versions: MCFC and PAFC.

Using the FCPower Model requires the user to follow four simple steps:

\section{Click Process Flow Diagram}

2. Configure the system on the Process Flow Diagram. Then, click the "Input Sheet" button to enter cost $\&$ performance values.

3. Enter cost and performance values using the Input Sheet as "Home Base."

a.The "Input Sheet Template" sheet is the main model interface

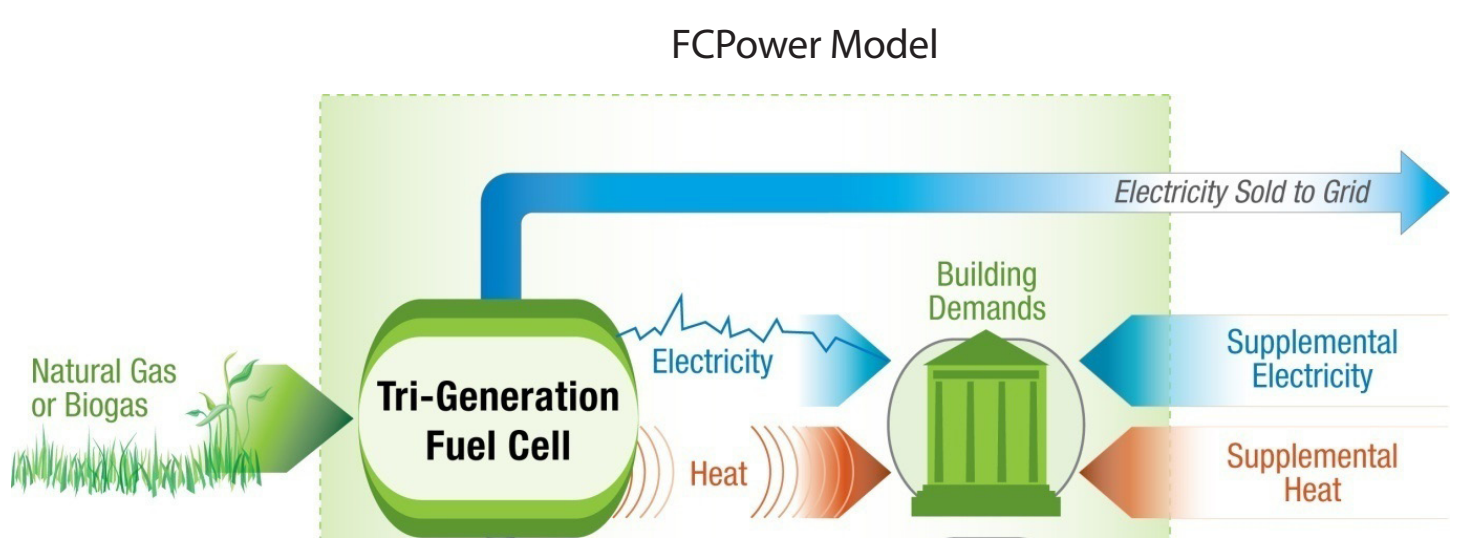

b.The subsequent slides will describe each section of the interface

c. Tools and defaults are available for most values

d.A lot of customization is possible for special case evaluations

4. Run the model by clicking the "Run Hourly Energy Profile" button.

The FCPower Model will identify the information that must be collected to make a comprehensive analysis of the fuel cell CHP system. In addition to evaluating the outputs of the FC Power Model, the project team should evaluate other factors that may affect the procurement decision:

- Manufacturer's warranty

- Available square footage

Estimate of the system's size
- Historic building issues

- Incentives (federal, state, local, utility, RECs)

Siting and site access

- Capacity of the local industry to supply and maintain system

Utility interconnection issues

- Electrical $/$ mechanical room issues

- Size, condition, and efficiency of existing heating systems 


\section{Step 4. Consider Project Requirements and Recommendations}

If, at this point, the screening has shown the fuel cell CHP project to be viable, the team should consider the following issues:

Utility interaction

Indemnity

NEPA compliance (if applicable)

- Air permitting

- Controls and communications

- Buy American Act provision (if applicable)

\section{UTILITY INTERACTION}

If a project generates electricity, it likely will include an electrical interconnection with the utility. The interconnection agreement is made between the organization and the utility regardless of the fuel cell CHP project developer's role. It is important to communicate with the utility about the proposed project early in the process. This ensures that all interconnection issues are taken into account early on, and helps avoid unexpected delays after significant effort has been expended.
Depending on the utility and the local distribution system design, the project can be adversely affected by expensive interconnection hardware and requirements. Some requirements can be addressed during the design stage through equipment specifications, which incurs only a nominal extra cost as compared to purchasing additional equipment.

Changes in the electricity tariff rate structure should also be explored and discussed with the utility. Based on the system's projected hourly and seasonal performance, a more optimal tariff could be available that could potentially offset both energy $(\mathrm{kWh})$ charges and demand $(\mathrm{kW})$ charges.

Thousands of utilities operate in the United States - each with unique rate structures and policies - so it is important for those planning an energy project to understand their rights as consumers and know what impact the system will have on future utility billings. For example, a utility could impose a standby charge to cover the cost of maintaining generation resources that are used when the system is not generating or more power is needed.

The system owner and utility will eventually develop an interconnection agreement that defines all the specific requirements and terms of the interconnection. Information on statespecific interconnection standards can be found at Interstate Renewable Energy Council Web site.* An example interconnection agreement document is available on the FEMP Web site. ${ }^{* *}$

\section{INDEMNITY}

Indemnity is an important issue that can arise with a CHP project. Indemnity is protection from risk and can take several forms. If a contractor or utility installs and operates a fuel cell (as with a PPA) they may request indemnity from damage to facility equipment resulting from the operation of the fuel cell CHP system. For example, a malfunctioning power conditioning unit may result in frequency variations and an outage. Repairs to a power conditioning unit and payment adjustments related to the loss of electrical and thermal production should be accounted for within the contract. However, if the frequency excursion resulted in damage to equipment served by the CHP system, the responsibility for those losses may not be clearly defined.

Utilities and contractors vary in their policies, but many will insist on having indemnification clauses included in their interconnection agreements. Federal agencies have their own policies with respect to indemnity, and facility managers should familiarize themselves with their agencies' policies to determine whether they can sign an interconnection agreement that includes an indemnification clause.

* Interstate Renewable Energy Council, www.irecusa.org/index.php?id=86 (accessed June 8, 2010).

** DOE Federal Energy Management Program (FEMP), http://www1.eere.energy.gov/femp/pdfs/fort_carson_interconnection.pdf (accessed on September 22, 2011) 


\section{NATIONAL ENVIRONMENTAL POLICY ACT (NEPA) COMPLIANCE}

Opinions differ among agency representatives about when NEPA should be addressed during the process, but it is best to consult the environmental expert responsible for NEPA early in the process. This will ensure that the expert is informed about the decisions and the directions regarding the site locations for the project.

\section{AIR PERMITTING}

Fuel cells have very low emissions, making the air permitting process easier. Some state regulators may recognize the superior performance of fuel cell systems and offer streamlined permitting processes based on their status as minor sources of pollution. In this case, the contractor is responsible for submitting the necessary documentation to the permitting authority and managing the air permitting process.

Usually, air regulators will require an emissions inventory including the types and amounts of air contaminants that the new power plant will release to the outside air; there often is a public comment requirement as well. The emissions inventory should be calculated on the maximum potential to emit for all current and new equipment that will be in operation for a continuous 8,760-hour year. While not likely to result in the requirement to install emission control systems, the air permitting process can be time consuming.

\section{CONTROLS/COMMUNICATIONS}

The fuel cell runs unmanned with remote communications access and control capability, allowing for considerable flexibility in monitoring and controlling the fuel cell.

The fuel cell is monitored and can be controlled via phone line. Further, some fuel cell manufacturers monitor all power plants worldwide 7 days a week, 24 hours a day. This allows factory control of the fuel cell if necessary. The fuel cell can also be accessed via phone line by remote computers equipped with the applicable software and security access. Should the fuel cell shut down for any reason, the fuel cell will notify the designated on-call person.

\section{BUY AMERICAN ACT PROVISION}

The Buy American Act restricts the federal government's purchase of supplies and construction materials that are not made domestically. The act contains many provisions, and when looking at the specification of components for a fuel cell system, it is difficult to determine which products comply and which do not. The current understanding is that a product manufacturer self-certifies its products as meeting the provisions of the Buy American Act, and that an audit system exists for this

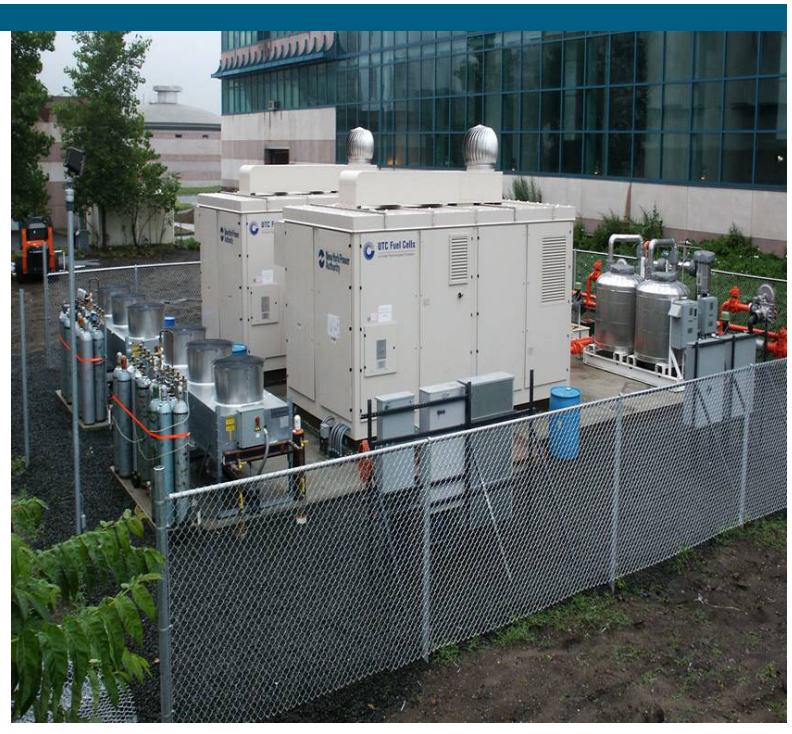

UTC Fuel Cells PAFC installation at NYSERDA 


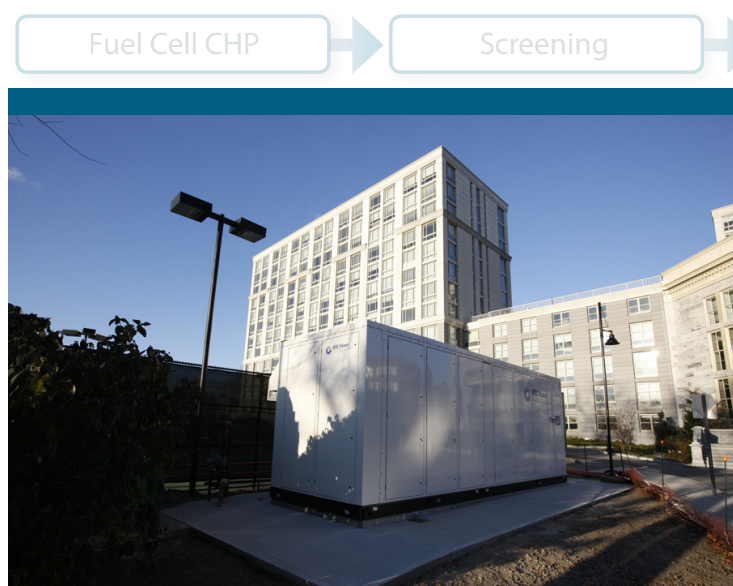

A UTC Power PAFC $400 \mathrm{~kW}$ fuel cell installed at the Octagon building on Roosevelt Island in New York. The Octagon is a Leadership in Energy and Environmental Design ${ }^{\oplus}$ (LEED) Silver 500-unit apartment community that made green history by becoming the first residential building in the State of New York to be powered and heated by a $400 \mathrm{~kW}$ fuel cell from UTC Power.

Photo courtesy of UTC Power certification process. This guide cannot confirm the correctness of this process, but it provides the best information available at the time of publication. If a project team decides to install fuel cell equipment that complies with the Buy American Act, the equipment can be purchased directly from a manufacturer that meets this requirement, or this requirement can be specified in the RFP and in the final contract. It is important to consult with an agency's buyers and procurement office about their latest understanding of the agency's specific requirements.

\section{FIRE AND SAFETY CODES}

Staff responsible for life safety, hazardous materials, and fire safety codes should be involved in the development of the project to ensure a safe working environment and to achieve compliance with prevailing fire codes. Fuel cell CHP projects may introduce a high fuel load in close proximity to personnel and critical systems. NFPA 853: Standard for the Installation of Stationary Fuel Cell Power Systems may be referenced for additional information.

As is typical with most electric utilities, any electric generator that is connected to the electric grid must install utility-grade interconnection control and protection devices with experienced vendors. Protective relays are designed to completely and quickly disconnect the generator from the electric grid in case of an electric excursion caused by either the generator or the grid.

\section{THE IMPORTANCE OF CODES AND} INTERCONNECTION

A healthcare facility in Austin encountered unexpected issues related to their fuel cell installation. The facility intended to connect the fuel cell to provide primary power to the health clinic building life safety circuits only, while sending excess capacity to the grid. A technical review revealed that life safety circuits were connected to all four of the building distribution panels and renovating the building wiring would prove to be too costly for this project.

An engineering review was then conducted with the goal of connecting the fuel cell to the building main distribution circuit to operate continuously at full capacity. This would allow all 200 kilowatts of power to flow from the fuel cell to the building in parallel with the grid during periods when building load exceeded the fuel cell capacity, and would also allow excess power to flow back into the grid. However, a subsequent engineering review revealed that the addition of the fuel cell would increase the current in the building distribution system beyond the capability of the installed switchgear. Upgrading the equipment proved to be problematic, and overcoming these issues proved too costly. A decision was made to interconnect the fuel cell directly to the utility electric grid at the high-voltage side of the building main transformer. 


\section{Project Finance}

Fuel cell CHP projects require significant up-front funding that may not be possible for some facilities. While some agencies are able to directly fund the installation of a fuel cell CHP system, most will seek alternative financing to facilitate these projects.

CHP systems are integrated into a facility's essential electricity and thermal energy systems. Implementing a fuel cell CHP project requires significant time, effort, and funding. It is highly recommended that cost-effective energy saving measures to reduce total energy requirements be implemented before planning on a fuel cell CHP installation. FEMP maintains an array of software and database tools to help Federal agencies analyze their energy use and to assist in the implementation of renewable energy, energy efficiency, and water efficiency projects.*

After the project has completed its initial screening and a project team has been formed, decisions about financing and contracting follow. Unless funding is designated for the project (i.e., through Congressional appropriations), this will be a more complex effort with private funding. If no direct funding is available, financing options must be considered. Before choosing an available financing option, review the options and information presented in this guide. Then contact a financing expert to discuss the specifics of the project and confirm the appropriateness of the financing decision. FEMP maintains a Web site and offers Webinars and workshops to educate participants on the different financing options available.**

\section{BUY THE FUEL CELL OR BUY THE ENERGY?}

Many planners who anticipate pursuing a fuel cell project are very likely assume that the agency will own and perhaps operate the fuel cell equipment; however, the benefits which can gained via a fuel cell project can be realized even if the equipment is owned by another entity. The role of the agency or federal facility in these projects may be better understood to be the customer of the power, whose long term contractual agreement to buy power for up to 30 years enables all of the other expenses to be bundled together. When a credit-worthy customer wants to pursue a project, the developer pulls together a project and tries to finance it. But over the initial life of the project, the actual owner of the CHP system is typically the developer.

* http://www1.eere.energy.gov/femp/information/access tools.html

** FEMP financing information can be found at www.eere.energy.gov/femp/financing/mechanisms.html (accessed July 26, 2010).

FEMP training information is available at www.eere.energy.gov/femp/services/training.html (accessed June 8, 2010).

\section{At-a-Glance}

Details on what's included in this section:

1. Power Purchase Agreements (PPA)

2. Energy Savings Performance Contract (ESPC)

3. Utility Energy Services Contract (UESC)

4. Enhanced Use Lease (EUL)

5. Advanced Ownership Models 
In some cases the federal agency may decide to own the equipment, to be integral to its operations and maintenance for reasons such as security or custody. However, federal agencies are not eligable for most incentives and projects, and fuel cell CHP projects can utilize a financing option that includes a non-agency partner.

\section{Power Purchase Agreements (PPA)}

A PPA is a legal contract between an electricity generator (provider) and a power purchaser (buyer). Contractual terms may last anywhere between 10 and 30 years. During this time the power purchaser buys energy, and sometimes also capacity and/or services, from the electricity generator. Such agreements play a key role in the financing of independently owned (i.e., not owned by a utility) electricity generating assets. The seller under the PPA is typically an independent power producer (IPP)

For a PPA project the energy provider secures funding for the project, maintains and monitors the energy production, and sells the electricity to the host at a contractual price for the term of the contract.

Financing for the project is delineated in the contract, which also specifies relevant dates like 1) when the project will be coming into effect, 2) when the project will begin commercial operation, and 3) the termination date on which the contract may be renewed or abandoned.

In some PPA projects, the host has the option to purchase the generating equipment from the PPA provider at the end of the term, renew the contract with different terms, or request that the equipment be removed. One of the key benefits of the PPA is that by clearly defining the output of the generating assets and the credit of its associated revenue streams, a PPA can be used by the energy provider to raise nonrecourse (i.e., provider assumes the equipment performance risks) financing from a bank or other financing counterparty.

\section{Energy Savings Performance Contract (ESPC)}

ESPCs have a long history of use in the federal sector and have primarily been used for energy efficiency projects. They are a possible means for a fuel cell CHP project. An ESPC is a guaranteed savings contracting mechanism that requires no up-front cost to the governing organization. An energy services company (ESCO) incurs the cost of implementing a range of energy conservation measures (ECMs) - which can include fuel cells and is paid from the energy, water, and operations savings resulting from these ECMs. The ESCO and the agency negotiate to decide who maintains the ECMs. Payments to the contractor cannot exceed savings in any one year.

\section{Utility Energy Services Contract (UESC)}

UESCs have been used in the federal government primarily for energy efficiency projects and now also are starting to be seen as a method of long-term financing. A UESC is an agreement allowing a "serving utility"* to fund initial capital expenditures associated with comprehensive energy- and water-efficiency improvements and/or demand-reduction services. Payback is received from subsequent cost savings that occur over a contract period. The utility may partner with an ESCO to provide the installation, but the contract is between the federal agency and the serving utility. This contracting mechanism primarily is for bundled energy-efficiency and renewable energy projects, and typically is not used for standalone projects. The steps in the UESC process are well defined, but utilities might describe them differently.

\section{Enhanced Use Lease (EUL)}

In the federal sector, EULs have been employed to implement infrastructure building projects. An

*See http://www1.eere.energy.gov/femp/technologies/derchp_fempassistance.html

** A "serving utility" provides natural gas, water or electricity to the site.

34 October 2011 
EUL is not an energy contract, but rather a real estate agreement that focuses on underutilized land. Prospective developers compete for the lease and payment can be either monetary or in-kind consideration. (In this case, renewable power can be part of the consideration.) The value of the lease is used to determine the amount of consideration. There are several factors that may limit the usefulness of EULs for fuel cell CHP projects. An EUL typically is used for large projects, for example, those having a capacity that is greater than the site load. Fuel cell CHP projects are less likely to be oversized than other options, and EULs are not likely to be used for fuel cell CHP projects.

\section{Advanced Ownership Models}

\section{Partnership Flip}

An institutional investor forms a partnership with the developer which owns the project. The investor will receive an allocation of tax benefits and cash distributions from the partnership until the investor achieves an agreed-upon, after-tax return. In the initial stages, the investor will receive a disproportionate allocation of the partnership's income or loss and any tax credit available to the partnership. When the investor's target return is achieved (the flip point), the investor's allocation of partnership items is reduced to a small portion.
The partnership generally will distribute its available cash flow $100 \%$ to the developer until the developer recoups its cash investment, at which point $100 \%$ would be distributed to the investor until the flip point is reached. After the flip, cash distributions would be made in accordance with partnerships allocations (e.g., 95\% to developer, $5 \%$ to investor). The developer will typically have an option on or after the flip point to buy out the investor's interest in the partnership at fair market value (FMV).

\section{Sale-Leaseback}

Generally, the developer will install, operate, and maintain the project and a customer will purchase power in a long-term PPA. The developer will incur all expenses related to the installation. To monetize the ITC (and any other other applicable tax benefits), the developer will sell the facility within three months after the service date. The investor will lease the project back to the developer for a lease term approximating the term of the PPA, and the developer will typically use the PPA as collateral for its lease payment obligations. The developer's revenue from the PPA is utilized to make rental payments under the lease.

The investor is considered the owner of the project for tax purposes, and it therefore claims the ITC (and any other) tax benefits. The investor shares its tax savings with the developer in the form of reduced rents. The developer will typically have an option at the end of the lease to purchase the project from the investor at its FMV.

In order for the sale-leaseback structure to work, the lease must be structured as a true lease for tax purposes. Typically the conditions would be: the lessee does not have the option to purchase the property for less than FMV, the lessor retains the risk that the property declines in value (e.g., the lessor does not have the right to require the lessee purchase the asset at a fixed price), and the leased asset is expected to have a significant residual value (e.g., $20 \%$ of its original cost) and a significant remaining useful life (e.g., $20 \%$ of its original estimated useful life). 


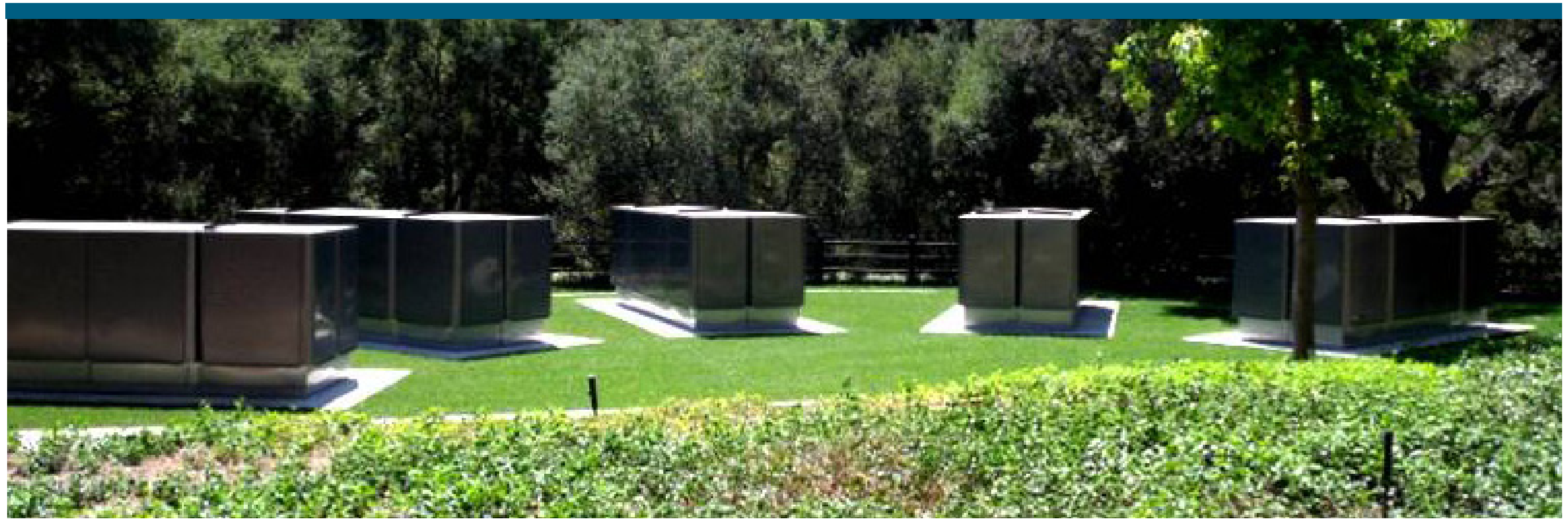

Photo provided by Bloom Energy

\section{Execution of a Fuel Cell CHP Project}

After a financing and contracting option has been selected, the next step is project execution. Each project follows a process that is unique to the financing and contracting option selected. The option selected by an agency may reflect several factors including 1) the size and scope of the CHP project, 2 ) the structure of existing energy contracts at the facility, and 3) the authority of the agency to utilize certain financing structures. In general, the ESPC option results in a more complex process than the UESC. For each of the options outlined in this section, general characteristics, case studies, project processes, and available resources are provided.

\section{At-a-Glance}

Details on what's included in this section

1. Agency-Funded Project

2. Power Purchase Agreenment (PPA) Project

3. Energy Savings Performance Contract (ESPC) Project

4. Utility Energy Services Contract (UESC) Project

5. Enhanced Use Lease (EUL) Project 


\section{EXECUTION}

IMPLEMENTATION »

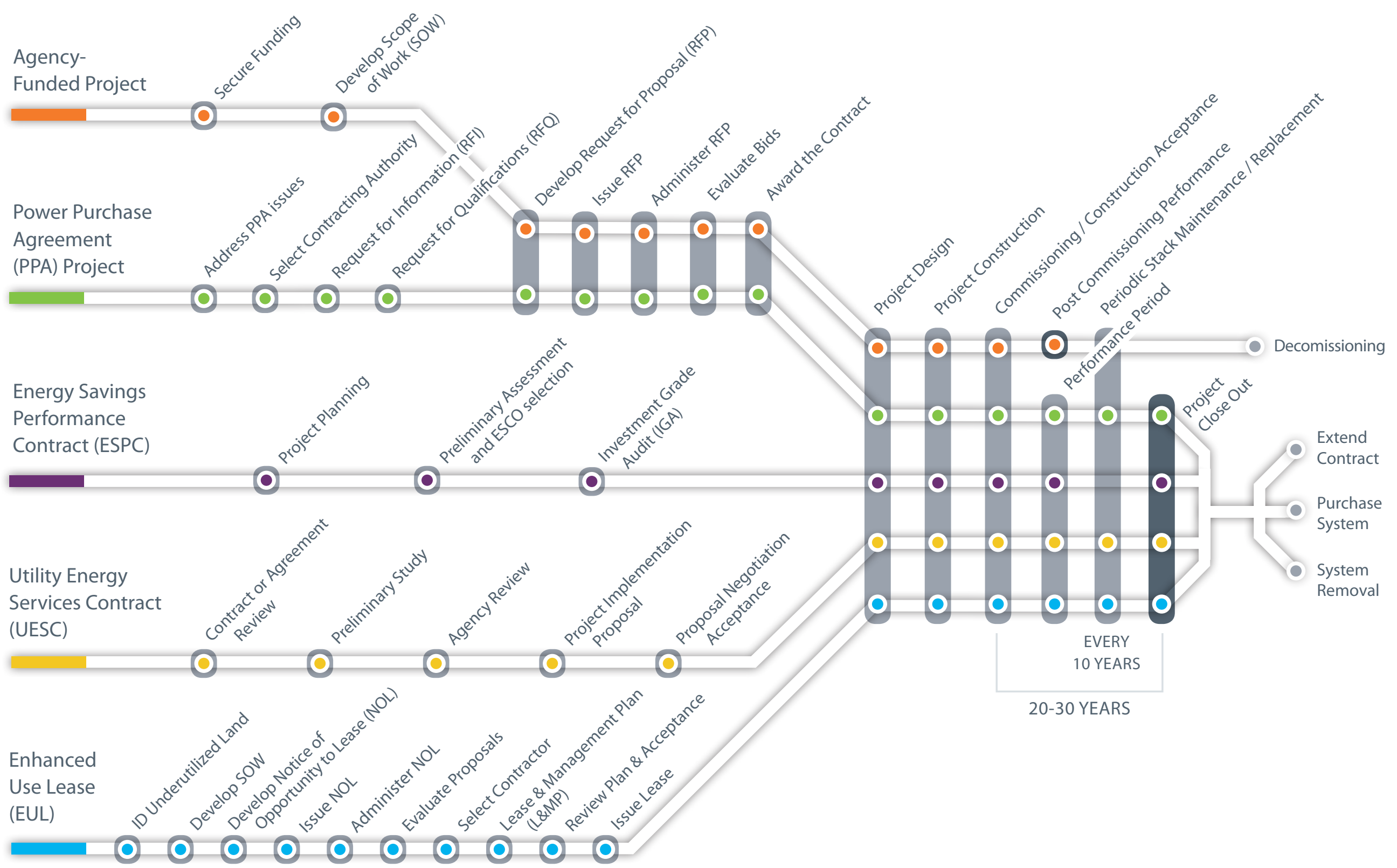

38 October 2011 


\section{Agency-Funded Project}

An agency-funded (or agency-appropriated) project is one for which funds have been designated for the outright purchase of a project - in this case, a fuel cell CHP project. The government owns the system and its energy production.

\section{Secure Funding}

Unless funding has been secured for this project, a case must be made for the project and funding must be requested. The primary source for this funding will be the individual agency, as it is the agency that is responsible meeting energy targets. Typically, the data for a costbenefit analysis should be in the project fuel cell CHP feasibility study. In some cases, additional data or analysis is needed.

\section{Develop the Scope of Work}

The scope of work (SOW) becomes the basis of the RFP used to solicit project proposals from fuel cell CHP developers. The form and detail of this scope of work are based on the selection of one of the following contract types:

- Design-bid-build

- Turn-key system

- Design-build
Many fuel cell contractors offer turn-key solutions and can assess the site, perform the design, and install the system.

Using the design-bid-build method, the scope of work is built around a complete design and specification of the system. This is a very prescriptive approach and the fuel cell CHP developer bids using the complete specifications. Typically this approach is used only when there are very specific design and engineering requirements which necessitate a defined design. In comparison, what is usually sought in fuel cell CHP projects is more performance based.

For the design-build process in the case of a fuel cell CHP project, the SOW is built around a performance specification. The performance specification typically is not prescriptive, and it allows developers to propose the most appropriate equipment.

The project's fuel cell CHP feasibility study should provide the basis for the project's scope of work. The team's energy systems expert is a key person in the development of this document. The SOW should include the following factors:

- Project site location relative to the facility or base

- Performance specification (or project design, in the case of design-bid-build)

\section{Steps to Follow}

1 Secure funding

2 Develop the scope of work

3 Develop a request for proposal

4 Issue a request for proposal

5 Evaluate proposals

6 Award the contract and design project

7 Construct the project

8 Commission the system

9 Post-commissioning performance 
- Site-specific requirements

n Type of fuel cell CHP system

A performance specification can include the following factors described below:

- The performance metric used to define the performance (This could include AC output, DC output, and delivered energy. Generally, it is not difficult to measure the output of a fuel cell CHP system. A performance specification for fuel cell systems, for example, could state minimum performance based on actual measured electrical and thermal output. A specification for fuel cell CHP could state that the system operate above a stated level of efficiency when measured [e.g., 80\%].)

- Fuel stack warranty (e.g., 90\% of nameplate rating for first 10 years)

- Interface requirements (Any physical and operational requirements that are imposed by connecting to existing systems (e.g., locations, voltages, temperatures) in such a way that performance of both fuel cell CHP and conventional systems is optimized.)

\section{Develop a Request for Proposal} (RFP)

An RFP is a document issued to the public to solicit proposals, in this case, from fuel cell CHP developers. An RFP describes how

\section{Agency-Funded Project}

\section{PROS}

Well-understood mechanism.

- Common to many federal capital projects.

- Does not incur any financing costs.

Long-term energy-cost reduction. (e.g., loan interest)

\section{CONS}

- Site is responsible for operations and maintenance arrangements (including inverter replacement), but can purchase an operations and maintenance (O\&M) service contract.

- No assurance of long-term performance (but can purchase optional long-term performance guarantees, which differ from a manufacturer's warranty).

- Could be more human-resource intensive (i.e., system operations and maintenance) than other options.

- Will not be able to apply available tax incentives. the proposal process is to be conducted and provides information that can be used as a basis for a developer's proposal. An RFP should include the following elements (listed alphabetically, not in order of importance).

- Clarification of party responsible for procuring permits

- Commissioning plan

- Criteria and process to be used to evaluate proposals

- Definition of infrastructure requirements (if any)

- Requirements for due diligence

- Explanation of how the proposal process is to be administered (e.g., proposal meetings, site visits, responses to questions)

- Limits on proposed project timeline

- Requirements for priced options (e.g., extended warranty and maintenance agreements priced in 5-year increments)

- Restrictions (or preferences) on parties allowed to submit proposals (e.g., small business, woman-owned, veteran-owned) (This is a policy decision that can be based on agency- or site-specific preferences.)

- Scope of work

- Specification of post-commissioning performance 
- Timelines for proposal process

CRITERIA AND PROCESS FOR EVALUATING PROPOSALS

Describing the criteria and the process to be used to evaluate the proposals helps developers to structure their responses and ensures that the project's primary issues are addressed. This also makes it easier to review proposals. The respondents address identified criteria in separate sections, eliminating the need for a reviewer to pick statements from the entire proposal that apply to the criteria. The three common processes used for evaluating proposals are "best value," "low price, technically acceptable," and "low price."*

\section{DUE DILIGENCE}

Describing how to handle due diligence on the developer's part has important contractual implications. Due diligence is the effort that a developer must put forth to fully understand the project and the risk of any unknowns that could arise. Contractually, the developer desires recourse if something unexpected comes up that is outside of its ability to perform or that will cause significant cost increases. In such circumstances, the developer might want to be able to walk away from the project or have the option to renegotiate. Agency options include having developers factor the risk into their proposals and be responsible for any unexpected circumstances that arise.

Depending on the project, due diligence can require considerable effort and expense. If this is the case with the project, or if this becomes apparent as the RFP process progresses, consider adding steps to the process. Additional steps can include an initial proposal review and the creation of a short list of prospective developers. Those on the short list are invited to continue with the RFP process, which includes expending additional effort and incurring more expense for due diligence. The purpose of this extra step is to assure the developers on the short list that they have a good chance at being successful, and that it is worthwhile to put forth the extra effort and expense required for due diligence. A site due diligence date-after which the developer will have entered into an irrevocable contract—should be specified.

\section{PROPOSAL PROCESS}

\section{ADMINISTRATION}

Proposal administration will include proposal meetings, site visits, and a planned process for answering questions so that all developers have access to the same information. There are many variations on how this can be accomplished.**

\section{POST-COMMISSIONING PERFORMANCE SPECIFICATION}

Consider adding a post-commissioning performance guarantee into the RFP. This guarantee ensures a minimum level of performance for a specified time after the system has been commissioned. An example of this is a fuel cell system that requires quarterly performance verification for the first year of service and which has a guarantee that the system output is to be at least $80 \%$ of calculated output based on actual electrical and thermal production.

\section{Issue a Request for Proposal}

After the RFP is complete, its announcement should be posted on a Web sites that are wellknown to developers. ${ }^{* * *}$

\section{Evaluate the Proposals}

The process for evaluating the proposals should have been established as the RFP was being developed. Evaluation of assumptions and exclusions included in the proposal requires particular care.

* Detailed information regarding source selection processes and techniques is provided in Federal Acquisition Regulation 15.1 at http://farsite.hil.af.mil/reghtml/regs/ far2afmcfars/fardfars/far/15.htm\#P14_1913.

** Best practices for contract/proposal administration are provided at https://www.acquisition.gov/bestpractices/bestcont.html. In addition, best practices for collecting and using contractor performance data is available at http://www.whitehouse.gov/omb/best_practice_re_past_perf.

***Examples include Federal Business Opportunities at http://www.fbo.gov and Green Power Network at http://apps3.eere.energy.gov/greenpower. 


\section{Award the Contract and Design the Project}

After the contract is awarded, the project design phase begins. It is recommended that design reviews be performed by a qualified, third-party, fuel cell CHP design expert at $25 \%, 50 \%$, and $100 \%$ design completion in order to confirm that site requirements are met. When utility interconnection agreements are part of the project, it is recommended that the utility also reviews and approves the electric interconnection and associated project design.

\section{Construct the Project}

The actual construction of the project typically is not much different from a standard mechanical electrical construction project such as a boiler replacement. Involvement with the local utility is essential to minimize approvals and inspections for the electrical and natural gas interconnections.

\section{Commission the System}

When the system is significantly complete and operational, it is recommended that it be commissioned and inspected by a thirdparty expert. It also is recommended that a good commissioning plan be established and agreed upon during the RFP process. The commissioning plan can be written into the RFP or be proposed by the developer. If proposed by the developer, then the agency energy systems expert should review it and make sure that it meets all requirements.

\section{Post-Commissioning Performance}

If the agency owns its system, then it is concerned with how it will operate over time and what recourse is available if the system ceases to operate according to expectations. Equipment manufacturers warranty their products and developers might provide a warranty on the system. The key questions are, "What does the warranty cover?" and "How can it be determined whether there is a problem if there is no obvious malfunction?" It is recommended that there be clear agreement with the developer regarding system performance expectations and what constitutes a system failure.

One option to help ensure system performance is to include performance verification as part of the contract. Performance verification should extend for a specified period after commissioning, and the verified performance should meet a predetermined threshold. An example of this is a fuel cell CHP system that requires quarterly performance verification for the first year of service and a contractual mandate that system output must be at least $90 \%$ of the design output.

Long-term monitoring of the system to understand reliability and operations and maintenance costs also is an important part of continued performance and economic benefits. The DOE Solar Energy Technologies Program can track performance and reliability of system installations.

\section{Power Purchase Agreement Project}

A power purchase agreement (PPA) is a legal contract between an electricity generator (provider) and a power purchaser (buyer). Contractual terms may last anywhere between 10 and 20 years. During this time the power purchaser buys energy (and possibly capacity and/or other services) from the electricity generator. Such agreements play a key role in the financing of independently owned (i.e., not owned by a utility) electricity-generating assets.

Under the PPA model, the PPA provider would secure funding for the project, maintain and monitor the energy production, and sell the electricity to the host at a contractual price for the term of the contract.

Financing for the project is delineated in the contract, which also specifies relevant dates of the project coming into effect, when the project will begin commercial operation, and a termination date on which the contract may be renewed or abandoned. All sales of electricity are metered to provide both seller and buyer with the most accurate information about the amount of electricity generated and 
bought. Rates for electricity are agreed upon in the contract between both parties in order to provide an economic incentive.

\section{Address Power Purchase Agreement-Specific Issues}

Before beginning the PPA process, confirm that PPAs are allowed in the state in which the project is located. PPA restriction information is available on the DSIRE Web site.* If DSIRE indicates that PPA status is unclear or apparently disallowed, it is recommended commission be contacted to help determine whether a PPA is legal for the site.

In general, PPAs typically are used only to implement larger projects (i.e., $100 \mathrm{~kW}$ or greater). This is based on several cost factors including transaction costs, financing costs, and economies of scale that make the PPA electric price lower. Recently, however, there have been indications that developers might consider smaller projects. For a relatively small project, several options exist. Multiple smaller fuel cell CHP projects can be 1) aggregated into one larger project, 2) bundled with energy efficiency in an ESPC or UESC, or 3) use agency funding.

To be economical, most PPAs require longterm contracts (i.e., 10 to 20 years) and some agencies do not have the authority to enter that the state's energy office or public utility into utility contracts of this length. Western Area Power Administration (Western) can help with long-term contracts for sites in its area.** Western can negotiate and sign the PPA on behalf of a federal agency, but the federal agency actually must select the fuel cell CHP developer.

Innovative methods to address the contract length limitations are being explored. An example is a long-term land-use agreement that includes a provision requiring the fuel cell CHP project developer to give the federal agency hosting the fuel cell CHP project right of first refusal on purchase of the power at a predetermined price. If the agency does not purchase the power, then the developer is free to sell it to the local utility. Before utilizing this method, investigate legal issues and determine electricity price. The developer could perceive more income risk and increase the price of electricity to compensate.

The U.S. Secretary of Defense has the authority (10 U.S.C. $\$ 2922 A$ ) to allow long-term contracts of up to 30 years in duration. The U.S. Navy plans to use this authority for the Navy Facilities Engineering Command Southwest's multiple-award contract. Approval through the U.S. Secretary of Defense, delegated to the U.S. Secretary of the Navy, will be sought under task order awards for these projects. any possible effect on a developer's proposed

\section{Steps to Follow}

Address power purchase agreementspecific issues

2 Select a contracting agent (if needed) Develop and issue a request for information (optional)

$4 \quad$ Develop and issue a request for qualifications (optional)

5 Develop a request for proposal

6 Issue a request for proposal

7 Administer the request for proposal

8 Evaluate the proposals

9 Award the contract (issue any needed indefinite delivery, indefinite [IDIQ] task order)

\begin{tabular}{ll}
10 & Design the project \\
11 & Construct the project \\
12 & Commission the system \\
13 & Monitor the performance period \\
\hline 14 & End contract oversight
\end{tabular}

* Available at www.dsireusa.org/summarymaps/index.cfm?ee=1\&RE=1 (accessed July 19, 2010)

** Available at www.wapa.gov (accessed June 8, 2010) 


\section{Select a Contracting Agent}

Determine the best contracting route to use. Typical options include local, regional, or headquarters contracting staff; Defense Logistics Agency (DLA Energy, formerly Defense Energy Support Center); or Western. Contact the contracting agent early after project identification to determine the best approach for the next steps in the process. Note that Western only signs the PPA, the agency for the site must select the fuel cell CHP developer.

\section{Develop and Issue a Request for Information (Optional)}

A request for information (RFI) provides a mechanism to obtain feedback on a proposed project to help refine and develop the RFP. Recommendations of types of projects for a specific site usually are helpful. In many locations, local air pollution control authorities will prefer fuel cell projects sized to meet on-site loads. The information can be used to refine the government's requirements for the scope of work used in the RFP. An RFI also allows industry to comment on the proposed process.

\section{Develop and Issue a Request for Qualifications (Optional)}

Another optional step that has been used for at least one federal site is a request for qualifications (RFQ). The purpose of the RFQ is to obtain a list of developers that are interested in the project and to learn about their specific qualifications. Developers that meet a stated qualification level can submit a proposal based on the RFP created in the subsequent step in the process. Developers typically decide which RFPs to respond to based on the limited development funds available. Developers have indicated a preference for this step because responding to an RFQ is relatively easy and inexpensive, and it reduces the field of competitors. A smaller field of competitors increases the probability of success, and qualified developers are assured that they are competing against other qualified developers. Receiving proposals only from qualified developers also can reduce the team's review workload and encourage qualified developers to invest more in their proposals, as there is a greater chance of being awarded the contract. The criteria to be used to qualify proposers must be stated. If the RFQ step in the process is not used, then the information that would have been received in the RFQ must be requested in the next step, the RFP. The following list includes items to consider including in the RFQ.

- Executive bios

- Letters from investors

- Professional affiliations

- Project experience (e.g., size, type, year built, customer)

- References

- Sample PPA

- Three years of audited financial statements

- Evaluation criteria and/or evaluation process, if selecting a short list of proposers

\section{Develop a Request for Proposal (RFP)}

An RFP is a document issued to the public to solicit proposals, in this case, from fuel cell CHP developers. The RFP describes how the proposal process is to be conducted and provides information that can be used as a basis for a developer's proposal. Sample documents can be found at the FEMP PPA Web site (www.eere.energy.gov/femp/financing/ ppa_sampledocs.html; accessed July 19, 2010). An RFP should include the following elements (listed alphabetically, and not in order of importance).

- Assignment of renewable energy attributes (ownership of the RECs)

- Drawings and maps (if available)

- Building restrictions (e.g., for use of natural gas) such as code limitations

- Contracting officer representative information (if applicable)

- Current energy-consumption data 
- Infrastructure requirements (if any), such as roads, fences, electrical system upgrades, tree removal, and determining which party is responsible for coordination and payment

- Environmental requirements such as NEPA, National Historic Preservation Act, Endangered Species Act, and other applicable federal, state, and local requirements

- Due diligence requirements

- End-of-project options

- Evaluation criteria and process

- Land-use agreement (include this as an attachment)

- Language of the PPA (optional)

- Limits on proposed project timeline

- Liquidated damages

- Proposal process administration plan (e.g., proposal meetings, site visits, answers to questions)

- Qualifications (if RFQ step is not used)

- Required submittals (can include acceptable pricing formats; for example, fixed-price only with escalation)

- Restrictions (or preferences) on parties allowed to submit proposals (e.g., small business, woman-owned, veteran-owned) (This is a policy decision that can be based on agency- or site-level preferences.)

- Safety restrictions for construction

- Site addresses

- Site design criteria

- Site fire standards and safety requirements

- Specific site-access requirements

- Fuel cell operating conditions requirements,

- Termination for convenience (provisions and termination schedule)

- Timelines for proposal process

\section{ASSIGNMENT OF RENEWABLE ENERGY ATTRIBUTES}

In some states, fuel cells qualify for renewable energy credits (RECs). If the project is eligible, the RFP must be clear on ownership of the attributes of the renewable energy generated. Depending on the markets for these attributes, they can be a major factor in determining the PPA electricity price. These attributes also might factor into the agency's renewable energy goal requirement (for information, contact the person responsible for such requirements). It is important to be clear that RECs include GHG emissions and all other environmental attributes, not the actual energy generated. If the RECs are sold, then replacement RECs must be purchased for credit towards the EPAct 2005 renewable energy goal. Present guidance is that RECs cannot count towards the E.O. 13514
CRITERIA AND PROCESS FOR EVALUATING PROPOSALS

Describing the criteria and the process to be used to evaluate the proposals helps developers to structure their responses and ensures that the project's primary issues are addressed. This also makes it easier to review proposals. The respondents address identified criteria in separate sections, eliminating the need for a reviewer to pick statements from the entire proposal that apply to the criteria. The three common processes used for evaluating proposals are "best value," "low price, technically acceptable," and "low price."* Evaluation criteria can include the following:

- Amount of energy generated on an average hourly, monthly, and annual basis over the term of the agreement, including a degradation factor

- Developer's experience and performance track record and references

- Developer's financial health

- Developer's ongoing, long-term ability to service the system

- Procedures to address specific site issues and requirements

- Implementation plan

- Local sourcing of components and labor

- Price 
goal if the RECs have already been sold or are retained by the developer.

- Performance plan

- Quality components

- Quality plan

\section{DUE DILIGENCE}

Describing how to handle due diligence on the developer's part has important contractual implications. Due diligence is the effort that a developer must put forth to fully understand the project and the risk of any unknowns that could arise. Contractually, the developer desires recourse if something unexpected comes up that is outside of its ability to perform or that will cause significant cost increases. In such circumstances, the developer might want to be able to walk away from the project or have the option to renegotiate. Agency options include, but are not limited to, giving developers what they want contractually or telling developers to factor the risk into their proposals and handle any unexpected circumstances that arise. Government agencies have language for equitable adjustments in price given increased scope of work, however. Also, in accordance with Federal Acquisitions Regulation (FAR) 15.208(e), a contractor has the right to withdraw its proposal at any time prior to the contract award. After the award, this becomes a contract termination issue.

\section{Power Purchase Agreement (PPA)}

PROS

- Renewable energy developer is eligible for tax incentives and accelerated depreciation, which should result in reduced energy costs.

- Agency is not required to provide up-front capital.

- Renewable energy developer provides operations and maintenance for the duration of the contract (no agency O\&M responsibilities).

- Government faces no financial risk on capital equipment.

- Agency typically receives a known long-term electricity or thermal energy price for a portion of the site load (which reduces the price risk of fluctuating utility energy prices).

- Developer has incentive to maximize energy generation of the system (compared to the case of a direct purchase of the system).

- Agency potentially can use available funds for a "downpayment" to get a better PPA price or a larger system.

\section{CONS}

- Transaction costs include a significant learning curve and time investment.

- Federal-sector experience is limited.

- Civilian agencies are limited to 10-year term PPA utility contracts (the U.S. Department of Defense [DOD] has 2922A authority, which permits 30-year terms).

- Site-access issues are complex.

- Management and ownership structures are complex.

- Contract termination penalties. 


\section{LAND-USE AGREEMENTS}

Land-use agreements govern the site access given the developer during the term of the project over both the construction phase and the production phase. The site-access requirements during these two phases can be quite different, which is why they could have different limitations and might be handled separately. The term of the PPA could start after construction is completed; therefore, certain terms and conditions of the PPA might need to be included in the construction phase. Land-use agreements typically take the form of leases, easements, licenses, or land purchase. Leases are for a limited term and usually are for exclusive occupation rights. Easements are a nonexclusive right to occupy and cross a property and primarily are irrevocable. Another option is for the fuel cell CHP developer to purchase nearby nonfederal land as the location for the system. When considering land-use agreement options, work with the team's legal counsel and real property staff, because agencies have different requirements. Sample land use agreements are available at the FEMP Web site.*

\section{LANGUAGE OF A POWER} PURCHASE AGREEMENT

It is recommended that preferred PPA language or key legal considerations for the contract agreement be included in the RFP, as this affects the proposals submitted by developers.
The PPA language incorporated in the RFP can be negotiated. It should, however, cover the pricing request for the term of the agreement (with escalators), termination fees for each year, and disposition of equipment at the end of the contract term. Experience has shown that RFPs that do not contain this language have produced administrative problems due to ambiguity.

System purchase options can be included if the agency foresees that it might want to purchase the system before the end of the PPA. This usually is considered after the sixth year of the project, after all the investment tax credits and accelerated depreciation benefits are exhausted. Buyout provisions are based on FMV or the present value of income expected from the remaining life of the PPA. The advantage of owning the system is that the owner does not have to pay for the power produced. If an owner has not signed an O\&M contract, however, then that owner is responsible for the operation and maintenance costs. At the end of the PPA contract, the agency could purchase the system for the FMV, extend the PPA (if allowed), issue a follow-on RFP, have the contractor abandon the system in place, or have the contractor remove the system.

\section{LIQUIDATED DAMAGES}

It is recommended that the contract include a clause regarding liquidated damages (LD). This clause should address and develop a method for calculating damage payments for the failure to perform contractual obligations. If failure to meet obligations has clear and quantifiable monetary consequences, then damages can be calculated easily. Damages that arise from failures that do not have clear and quantifiable monetary consequences should be addressed by this clause. Most examples of situations to which an LD clause would apply are related to not meeting stage-gate requirements, such as those that follow:

- Design submissions

- Permitting

- Procurement of modules

- Commissioning or completion

\section{PROPOSAL PROCESS ADMINISTRATION}

The proposal administration description includes the timing and location of proposal meetings and site visits, as well as the process for answering questions. The proposal meeting is the forum for presenting the project requirements in detail to interested developers and the opportunity for developers to ask questions. The site visit enables interested developers to assess site conditions and to ask additional questions. The site visit can be held in conjunction with the proposal meeting or be conducted separately. Depending on the site conditions and the process chosen, additional site visits could be necessary for respondents to perform additional due diligence. 
Questions that arise during and after the proposal meeting and site visit must be handled such that all developers have access to the same information. There are many variations on how this can be accomplished. A recommended method is to write down every question, answer each, and post the questions and answers on a Web site. This process can help avoid variation in answers, minimize participant misunderstanding, and eliminate the possibility of one party receiving more information than another.

\section{REQUIRED DESIGN AND CONSTRUCTION SUBMITTALS}

The RFP should be clear on what submittals are required from the developers for the proposals and, if successful, what is required during the design and construction of the system. The proposal submittal could include the following components:

- Conceptual layout

- Detailed project implementation plan

- Line diagram (electrical schematic diagram)

- Projected energy performance (average hourly, monthly, and total with degradation factored over the term of the agreement)

- System components, such as modules, inverters, and racking, with specifications and warranty information
Submittals required during the project construction should include as-built drawings and final system specifications.

\section{SYSTEM REQUIREMENTS}

The system requirements section of the RFP should include a description of expectations regarding the project and any pertinent information that will help the developers give a solid proposal. Include one or more location options and, if desired, a minimum system capacity for each location. Note whether each fuel cell CHP system will be evaluated separately or as part of a group. System requirements should not be prescriptive and instead should give developers the opportunity to propose a system that is most economical based on individual experience.

The system description should include expected technology type, size or performance range, location, and any site-specific considerations or limitations (e.g., access to natural gas and interconnection with existing thermal and electrical systems). Site information that should be provided, if available, includes pertinent electrical information and drawings, site characteristics, site load information (maximum/minimum demand for each month), consumption information (hourly, if available), environmental factors, interconnection options, acceptable inverter locations, and any other pertinent information. Sample RFPs are available online at the FEMP Web site.*

\section{Issue a Request for Proposal}

After the RFP is complete, announce it somewhere that developers can find it. Use prominent Web sites that are familiar to most developers. $* *$

\section{Administer the Request for Proposal}

After the RFP is issued, follow the defined timeline and described RFP process. Adjust both as necessary if unforeseen events arise. This step may include site visits, pre-bid meetings, and correspondence related to questions and answers related to the project.

\section{Evaluate the Proposals}

Assemble a small team to evaluate the proposals received. The number of team members to include depends upon the specific project, but the team should have at least three people. Most of the people on this team probably will come from the project team, but other stakeholders can be considered as well:

\section{- Energy manager}

- Facilities manager

- Legal/procurement expert

* http://www.eere.energy.gov/femp/financing/ppa_sampledocs.html (accessed July 19, 2010)

** Examples include Federal Business Opportunities at http://www.fbo.gov and Green Power Network at http://apps3.eere.energy.gov/greenpower. 
- Project manager

- Site manager (if managers for different areas of site)

- Energy systems expert

The process for evaluating the proposals should have been established as the RFP was being developed. It is recommended that the meritreview sessions be set up well in advance to ensure the availability of key personnel. Follow the proposal evaluation criteria described in the RFP and, from the start, clearly define the meaning of each criteria and score. Each agency also likely to have its own review process to follow, which it is important to address as well.

Evaluating the assumptions and exclusions included in the proposal requires particular care. Are the assumptions and exclusions reasonable based on the information available about the project? Do they demonstrate good judgment? What should be avoided are costly change orders or price increases that can come with the low cost proposals that are based on poor assumptions or excessive exclusions. The risk is that what initially seems to be the lowest cost proposal actually could be more costly in the end.

When evaluating proposals for pricing options, be aware that if an acceptable pricing structure is not specified in the RFP, then many different options could be given. Common pricing structures include escalation factor (usually $1 \%$ to $3 \%$ ), firm-fixed price, utility-rate linked, or a de-escalation factor. An escalator is the percentage that the PPA price per kilowatt-hour will increase annually. A first year price with escalator usually is less than a fixed price but will increase to more than the fixed price during the term of the PPA. Typically, an evaluation of these pricing structures can be based on lowest present cost for the expected production and term of the project.

The winning proposal should be compared to current utility rates and the expected future rates, based on inflation and discount rates taken from the National Institute of Standards and Technology (NIST)/Energy Information Administration (EIA) "Energy Price Indices and Discount Factors for Life-Cycle Cost Analysis-May 2010, Annual Supplement to Handbook 135."* Other price forecasts also can be used for comparison purposes to help the site decide whether a contract award is recommended. Other time- and project-specific requirements, such as when funds will be available to pay for production (e.g., a large amount of funds might be available in the first year of the project, but perhaps more significant funds will not be available until a subsequent year) also can be considered. As noted, standby charges and possible utility tariff changes should be compared to historic and projected utility costs.

\section{Award the Contract}

The process for contract award depends on the type of evaluation used and could include negotiations with the proposers. Several options can be used for awarding the contract.**

- Award Based on Proposal. The contract is awarded solely on the merits of the proposal as determined when the proposals were evaluated. This scenario is very unlikely, as discussion almost always is required.

- Award with Discussions. The contract is awarded on the merits of the proposal but is contingent, in part, on further discussions to clarify understandings, agreements, or responsibilities.

- Award with Discussions and Negotiation The contract is awarded on the merits of the proposal but is contingent on further discussions and negotiations. This can be used in the case of receipt of a good proposal that requires adjustments to meet the specific needs of the project. This approach can be employed when unanticipated ambiguities in the RFP or project specifics arise during the RFP process and result in varied proposals that do not quite meet the objectives.

- Award with Best Proposal. In this process, a short list of developers is created based on the proposal. Those on the short list then are asked to develop their best final proposal 
revision (FPR). This request for FPR can include information such as updated pricing and design specifications. At this point it is assumed that developers on the short list are technically competent, therefore the evaluation primarily is based on price unless the best value method is employed. This approach also can be used in conjunction with projects that have significant due diligence issues, as noted in the "Develop a Request for Proposal" section. It is recommended that the short list include not more than three developers. As the number of developers on the short list increases, the odds of success decrease for each individual developer, as does the willingness of the developers to expend money and effort to tighten their proposals.

\section{Design the Project}

After the contract is awarded, the project design phase begins. The design parameters that the system designer will work within should be clear from the RFP, the final revised proposal, any negotiations that occurred during the RFP process, and due diligence performed by developer. The design kickoff should confirm these design parameters for all parties. It is recommended that design reviews be conducted by a qualified, third-party, fuel cell CHP design expert at $25 \%, 50 \%$, and $100 \%$ design completion stages in order to confirm that requirements are met. A thorough design review always is faster and less expensive than fixing design flaws later. To help with the design reviews, a "Fuel Cell CHP Project Design Evaluation Checklist" is included in Appendix B.

\section{Construct the Project}

During project construction, the primary considerations are regarding coordination with the developer. To enable a successful coordination during this phase, first identify a single point of contact. Major areas of coordination include the timing of work (particularly if construction could interfere with the site's mission), critical deadlines (especially those regarding incentives), interconnection issues (including interconnection and net metering agreements), and incentive applications. The final piece of the construction process is the commissioning of the system, which makes the system interconnection and start up possible.

\section{Commission the System}

Although the system is owned and operated by a third party and the agency is just purchasing the energy output of the system, the system still is located on the agency's site and the agency has an interest in how well the system performs (for the credit toward renewable energy targets). Commissioning of the system is the responsibility of the fuel cell CHP developer; however, it is recommended that the agency be aware of any issues and reports resulting from the commissioning. A good commissioning ensures that the system has been installed and is operating to specifications. It also confirms that there are no apparent safety issues due to poor installation (e.g., damaged wire insulation, unprotected high-voltage connections). There could also be requirements from the REC purchaser that must be met. A "Fuel Cell CHP Commissioning Checklist" is provided in Appendix B.

\section{Monitor the Performance Period}

The primary duty during the PPA's performance period is to track actual production and pay for electrical production. Operation and maintenance usually are the responsibilities of the developer. If the developer owns the RECs produced by the project and the agency needs to meet renewable energy targets, then it can purchase replacement RECs every year.

\section{End Contract Oversight}

The end of the PPA is characterized by the decision on the preferred system purchase or other termination option (discussed above in "Language of a Power Purchase Agreement" section). This could be oversight of the system removal, extension of the PPA, or purchase of the system and continuation of the O\&M. The choice of options most likely will be influenced 
by circumstances existing 20 years in the future, and this should be taken into account when developing the options at the start of the project.

\section{Energy Savings Performance Contract (ESPC)}

ESPCs have a long history of use in the federal sector and have primarily been used for energy efficiency projects. They are increasingly being seen, however, as a long-term financing method for fuel cell projects. An ESPC is a guaranteed savings contracting mechanism that requires no up-front cost. An energy services company (ESCO) incurs the cost of implementing a range of energy conservation measures (ECM)which can include fuel cells - and is paid from the resulting energy, water, and operations savings. The ESCO and the agency negotiate to decide who maintains the ECMs. Payments to the contractor cannot exceed savings in any one year.

Multiple contracting options are available to agencies interested in an ESPC. DOE offers an indefinite delivery, indefinite quantity (IDIQ) contract designed to make an ESPC as cost-effective and easy-to-implement as is possible for Federal agencies. Several ESCOs are prequalified and have accepted the terms of the IDIQ contract; these companies thus can respond to project requests. The U.S. Army also has an IDIQ contract in place as an alternative to the DOE option. The discussion below focuses on the DOE ESPC process, which is explicitly defined. Additional information is available on the FEMP Web site.* Also, FEMP has extensive resources including contract templates, flowcharts, and process guidance on its Web site.**

\section{Plan the Project}

The DOE Super ESPC (a DOE IDIQ contract with approved energy services companies) requires the involvement of a federal financing specialist (FFS) and a project facilitator (PF). The services of the FFS are provided at no cost throughout the project. The services of the PF are provided by FEMP at no cost up through agency review of the preliminary assessment. When further PF services are required, they are contracted on a reimbursable basis for labor and travel costs. Once the FFS and PF have been identified, assemble the site team, FFS, and PF to put together a notice of opportunity that will be sent to all energy services companies on the approved list.

The notice of opportunity can be as simple as a one-page letter that gives a summary of what might be included in the project and includes a request for a response from interested ESCOs. The notice of opportunity could include site data for known energysystem improvements, indicate the desire for renewable energy projects, include a schedule of the ESCO site visits, and provide the timeline for submission of a preliminary assessment (PA). It is recommended that the project scope be open to all types of projects. As in any federal procurement, it is important that fair opportunity be given to all potential contractors, especially if large projects materialize after some ESCOs are removed from consideration.

If details are provided in a notice of opportunity or site data package, the results of a renewable energy screening may be included. The National Renewable Energy Laboratory (NREL) offers a renewable energy optimization screening at no cost to federal agencies upon request. Other energy efficiency screening reports may also be included on the FEMP Web site.*** Site information for other systems that should be targeted for upgrades can be included along with utility usage data. Requested information from the ESCO could include qualifications, past performance, and markups; these can help in the ESCO-selection process that the project team must develop. The ESCOs that are interested in the project submit the requested information to the agency's contracting officer's representative (COR). The team evaluates the responses and one or more ESCOs to proceed to the next step.

* Available at www.eere.energy.gov/femp/financing/espcs.html (accessed June 10, 2010)

** Available at www.eere.energy.gov/femp/financing/espcs_resources.html (accessed June 19, 2010)

*** Available at www.eere.energy.gov/femp/financing/espcs_techplanning.html (accessed June 8, 2010) 


\section{Perform a Preliminary Assessment and ESCO Selection}

The beginning of the preliminary assessment (PA) phase is a kickoff meeting between the site team and the selected ESCOs. A preliminary site assessment follows the kickoff meeting. This assessment identifies the renewable energy and energy-

efficiency measures to be considered for the project. The ESCOs develop preliminary assessments (proposals), which the team then reviews. Sample criteria for evaluating a PA can be found online at the FEMP Web site.*

The ESCO selection can occur before or after the preliminary assessment depending on ESCO responses in Step 1(Plan the Project). Contracting officers $(\mathrm{CO})$ are given broad discretion in the DOE IDIQ as to their contractor selection approach. Regardless of the approach and the timing of the selection, fairness must be demonstrated to all contractors and the approach must follow section H.3 of the DOE IDIQ. Aside from some exceptions to "Fair Opportunity," the agency CO must consider price in the selection decision. When the agency downselects to a single ESCO, the agency CO must document the basis for the downselection. The DOE IDIQ contract can be found online at the FEMP Web site.**

During this phase, the agreement for continuing the PF services - which are required for the ESPC process - must be finalized. These services are estimated to cost between $\$ 50,000$ and $\$ 75,000$ for an average project.

\section{Perform an Investment Grade Audit (IGA) to Award}

The IGA is the detailed assessment of prospective energy and water projects. This audit determines the economic viability and bankability (investor financing requirement) of the project. The audit is a joint effort between the ESCO and the agency team, and is characterized by ongoing negotiation. Items that are a product of this effort and must be agreed upon include baseline usages, correct calculation methods, and appropriate measurement and verification $(\mathrm{M} \& \mathrm{~V})$ procedures. The result of this effort is a final proposal that is produced by the ESCO. Note that all ESCO costs up to this point are borne by the ESCO, and that the IGA is a significant effort that can cost $\$ 1$ million or more (for complex projects). Agency review of the proposal and final negotiations precede the award of the task order.

Before the contract is completed, the task order RFP must be developed. The IDIQ contract language is the default contract language, however, the task order RFP includes agency-specific contract language that supersedes corresponding IDIQ contract language; its development can therefore be a significant effort. The final contract consists of three pieces: the task order RFP, the IDIQ, and the final proposal; it is important to ensure consistency between all three documents. The final result of this phase is the task order award.

\section{Steps to Follow}

Plan the project

2 Perform a preliminary assessment and ESCO selection

3 Perform investment grade audit to award

4 Design the project

Construct and install the system

6 Commission the system

Monitor the performance period

Perform project close out

* Available at www.eere.energy.gov/femp/pdfs/4_4_preminaryassessmentguidance.pdf (accessed July 19, 2010)

** Available at www.eere.energy.gov/femp/pdfs/generic_idiq_espc_contract.pdf (accessed August 20, 2010) 
Under an ESPC, the title to the improvements installed under the ESPC transfers to the agency upon final project acceptance. For fuel cell CHP energy projects or the fuel cell piece of a larger project, the agency $\mathrm{CO}$ has the discretion to allow private-party ownership of renewable energy systems by the ESCO or a third party. With private-party ownership, there is an option to implement an energy services agreement as part of the ESPC. To take advantage of tax benefits, an ESA allows a third party (ESCO or investor) to hold title to the fuel cell CHP energy portion of the project and to reap the tax benefits. It also enables the third party to pass some of these benefits back to the agency to improve the economics of the project. For projects in which fuel cell CHP energy generation only reduces site load, the energy production is measured and counted toward offsetting utility energy purchases. When entering into an ESA, the agency may also consider buyout or removal provisions that come into effect at the end of the project.

\section{Design the Project}

After the contract is awarded the project design phase begins. The design parameters that the system designer will work within should be clear from the final proposal. The design kickoff should confirm these design parameters for all parties. It is recommended that design reviews be performed by a qualified, thirdparty, fuel cell CHP design expert at $25 \%$,
$50 \%$, and $100 \%$ design completion in order to confirm that requirements are met. A thorough design review always is faster and less expensive than fixing design flaws later. To help with the design reviews, a "Fuel Cell CHP Project Design Evaluation Checklist" is included in Appendix B. After the design has been reviewed and accepted, a notice to proceed is issued, and construction can begin.

\section{Construct and Install the System}

The construction phase of the process is much like that of any other construction project; however, most of the team's work is to coordinate with the construction crews, ensure that the site mission is not unduly impeded, and to meet any milestones or agency contractual obligations. The contract should be clear on which party is fiscally responsible if obligations are not fulfilled.

If a project is complex, then there could be partial project acceptances that occur as different measures are completed. The motivation for partially accepting projects is to start accruing savings that can be set aside until final project acceptance. Any money set aside due to savings or other agency funding (e.g., funding that was earmarked for upgrades that the ESCO now is performing) can be used to buy down the project financing before final project acceptance. This reduces interest payments over the life of the project and provides potentially significant savings. After the project is accepted, the payments cannot exceed savings, and there is no additional option to buy down or prepay the project unless a termination for convenience is exercised. When engaging in partial project acceptance, an agency must commission the measure and implement the $\mathrm{M} \& \mathrm{~V}$ protocol to verify the savings before it can start banking any savings.

\section{Commission the System}

When the fuel cell CHP energy system is significantly complete and operational, the ESCO will commission the system. It is recommended that the agency have a knowledgeable representative present at the commissioning to represent the agency's interest. This is where superior system design helps ensure good value. A top-notch commissioning makes certain that the system has been installed properly and is operating to specifications. It also confirms that there are no apparent safety issues due to poor installation (e.g., damaged wire insulation, unprotected high-voltage connections). The commissioning plan can be written into the final proposal (a "Fuel Cell CHP Commissioning Checklist" is included in Appendix B). It is important to ensure the quality of the installation and to make sure that the measures are operating as expected. When commissioning is satisfactorily complete and post-installation $\mathrm{M} \& \mathrm{~V}$ has started, final project acceptance is given and the performance period phase of the 


\section{Energy Service Performance Contract (ESPC)}

\section{PROS \\ CONS}

- The 25-year contract length fits well with longer renewable energy paybacks.

- The performance is guaranteed.

- The operations and maintenance can be included as part of the contract.

- The agency in charge of the site can require that fuel cell CHP be a part of the project.

- A project facilitator is assigned (FEMPfunded through initial proposal or preliminary assessment).

- The sale of excess electricity and thermal energy is allowed (EISA provision).

- The agency contracting officer has the discretion to allow ESCO or third-party ownership of the renewable energy conservation measures eligible for federal and state tax incentives.

project begins.

\section{Monitor the Performance Period}

The performance period involves measuring ECM performance and verifying savings annually, confirming ESCO or agency maintenance to keep project measures operating
- Since ESCOs traditionally do not own assets, it is difficult to monetize tax incentives related to fuel cells.

- Not recommended for renewable-only projects.

as expected, and ensuring agency payments on the contract. The M\&V and maintenance activities are carried out as specified in the contract. Any discrepancies or objections to the reported savings must be resolved and then the annual payment can be made. It is important to decide whether to pay in advance or in arrears; the difference equals a year of interest on the project loan.

\section{Close Out the Project}

At the end of the performance period the task order is closed out. At this point the agency will no longer be required to make payments on the contract.

\section{Utility Energy Services Contract (UESC)}

UESCs, like ESPCs, have a history of use in the federal government sector primarily for energy efficiency projects. Now, these contracts are also being seen as a method of long-term financing, with the added benefit of usually being a sole source contract. A UESC is an agreement that allows a "serving utility"* to provide an agency with comprehensive energy- and water-efficiency improvements and demand-reduction services. The utility could partner with an ESCO to provide the installation, but the contract is between the federal agency and the serving utility. This contracting mechanism primarily is for bundled energy-efficiency and renewable energy projects, and typically is not used for standalone renewable energy projects. The steps in the UESC process are well defined, but different utilities might describe them differently. The process steps described below are representative of the general process. ${ }^{* *}$

An effort currently is underway to define a process for a utility renewable electric service contract (URESC) for parties interested in pursuing a standalone fuel cell CHP electric project with a utility in a specific service territory. The URESC 
concept is envisioned to produce a cross between a PPA and an UESC.* It is hoped that an URESC project will commence soon and define this financing and contracting option.

For general information and assistance with UESCs, the FEMP offers "Utility Energy Service Contract: Enabling Documents."** available at www.eere.energy.gov/femp/pdfs/ uesc_enabling_documents09.pdf (accessed June 7, 2010).

\section{Introduction: Contract Agreement Review}

This first step provides a more detailed description of the UESC, discusses whether the local utility offers one, and examines what agreements might be in place (if a UESC is offered). It is important to review available agreement or contract options to understand the types of projects they cover. If the type of project being considered is not covered under an existing agreement, then an agreement can be developed with the utility.

The three UESC contract or agreement types are the area-wide contract (AWC), the basic ordering agreement (BOA), and the master agreement. An AWC is a blanket contract that the GSA establishes with utilities that permits federal agencies to place orders with a utility (if contracted) for services offered under the AWC.
A BOA is made between an agency and a utility and establishes general terms and conditions for future contracts. Model agreements are template agreements developed for federal agencies, and contain required clauses for federal contracts. Template agreements can be used in whole or in part as the basis for an AWC or a BOA, or they can be used alone to form a master agreement between the agency and utility. A list of AWCs currently in place and a list of master agreements can be found on the FEMP Web site. ${ }^{*}$ It is important to understand that if none of the local utilities offer an UESC, then the FEMP and GSA have resources to inform the utility about UESCs (with the goal of urging the utility to offer one).

If an area is serviced by more than one utility, it is recommended that "fair consideration" be given to all utilities servicing the area. When performing a fair consideration of a utility, request descriptions of its capabilities and experience, references, and a disclosure of its markups on projects of this type. If considering a very complex project (greater than $\$ 10$ million), the agency could choose to request more information from the utilities to help make a choice between them. After selected utilities express interest in the project, execute a justification and approval (J\&A) document. It should be noted that UESCs do not have a traditional RFP process, unlike the agencyfunded or PPA procurement mechanisms.

\section{Steps to Follow}

Introduction: Contract or agreement review

Perform a preliminary study

Perform an agency review

Project implemention proposal (investment grade audit/detailed feasibility study)

5 Negotiate and accept the proposal (construction contract)

* Available at www.eere.energy.gov/femp/financing/uescs_types_html (accessed June 10, 2010)

** Available at www.eere.energy.gov/femp/pdfs/uesc_enabling_documents09.pdf (accessed June 7, 2010) 
FEMP can provide expert help in working through the UESC. FEMP project facilitators and federal financing specialists have expertise

\section{Utility Energy Services Contract (UESC)}

\section{PROS}

- The UESC contract term is 10 to 25 years, and varies by agency (average project term is 14 years). The EISA (section 513) prohibits agency policies that limit privately financed contract terms to a maximum period of less than 25 years.

- The GSA legal opinion states that extended utility agreements are allowed (Utility Energy Services Contracts: Enabling Documents, www.eere.energy.gov/femp/pdfs/ uesc_enabling_documents09.pdf; accessed June 7,2010$)$.

- Utilities now are eligible for a renewable investment tax credit (the utility must own a renewable energy plant).

- Interconnection, tariff, and standby issues should be minimal with utility ownership (but this is not always true and should be explored prior to proceeding).

- Utilities are interested in a wide range of project sizes (large and small dollar value projects).

- A relationship already exists.

- Utilities often have access to reduced financing rates due to their financial strength. in these types of projects and with alternative financing mechanisms.*

\section{CONS}

- Not all utilities offer UESCs (FEMP is helping utilities launch UESC programs).

- The utility might have limited renewable experience and could be uncomfortable with renewable projects.

- Issues could arise regarding contracts for terms of more than 10 years; 10 years is acceptable for energy efficiency but renewable energy projects usually require a longer contract to be economically feasible.

\section{Perform a Preliminary Study}

A preliminary study essentially is a walkthrough of the facility. The walkthrough constitutes a preliminary audit that is seeking energyefficiency and renewable energy opportunities. The result of the audit is a report that outlines possible project scope and preliminary economics. This report is used as the basis of the decision to proceed with the project's next steps.

\section{Perform an Agency Review}

An agency review examines the preliminary study report. The review should look at the planned SOW and confirm that all projects that are deemed necessary (e.g., failing equipment replacement, fuel cell CHP project) are included in the scope. Additionally, economics and term of contract should be considered in the decision to move forward with the next step.

\section{Project Implementation (Detailed Feasibility Study)}

The two main components of this step are performing an IGA and drafting a project proposal based on that IGA. The IGA can be paid for up front or rolled into the financing of the overall project. The proposal provides the project scope and description, costs, schedule, and other pertinent information.

* For more information on types of UESCs, see www.eere.energy.gov/femp/financing/uescs_types.html (accessed June 7, 2010). 


\section{Negotiate and Accept the Proposal}

If the proposal meets all of the needs for the project, then it either can be accepted as is or changes can be negotiated. It is anticipated that the agency-review step will address expectations of which items are to be included in the proposal, but it is important to confirm that all of the required items are incorporated. Any critical design requirements also should be checked and confirmed (e.g., design requirements for integration of the thermal output of the CHP system). Cost information should be checked and confirmed with experts on the team and be negotiated, if that is deemed necessary. Include buy down, prepayment, and termination formulas, as they can reduce finance costs and alleviate future contract administration problems. After achievement of a mutually acceptable proposal, authorization to award the contract must be received. Typically, a work release letter or purchase order (PO) that references the requirements of the master contract and the specifics of this proposal is drafted and signed.

Another major contract consideration is determining who takes title to the renewable energy portion of the project. The UESCenabling legislation is silent on whether the agency must take title to the project (except for the U.S. Department of Defense, which must take title, but with no specification as to when). It is recommended that the utility be given title to the project for at least a few years (currently 6 years) so that tax benefits can improve the economics of the project.

\section{Enhanced Use Lease (EUL)}

In the federal sector, EULs have a history of being used to implement infrastructure building projects. Now, they are also being used to realize fuel cell CHP energy projects. An EUL is a real estate agreement that focuses on underutilized land. Prospective developers compete for the lease, and payment can be either monetary or in-kind consideration (in this case, renewable power can be part of the consideration). The value of the lease is used to determine the amount of consideration. An EUL typically is used for large projects, for example those having a capacity that is greater than the site load. A few agencies have the authority to execute an EUL.

\section{Identify Underutilized Land}

The prerequisite for an EUL is that the site has "underutilized" land that is not "excess property" as defined in 40 U.S.C. $\$ 102$. Identify land that meets the "underutilized" requirement and that is a reasonable site for a fuel cell CHP project. A market appraisal must be completed to determine land value.

\section{Develop the Scope of Work}

The SOW becomes the basis of the notice of opportunity to lease (NOL) used to solicit project proposals from fuel cell system developers. This is a statement of all the requirements of the project. The fuel cell CHP feasibility study should provide the basis of the project's SOW. The team's energy systems expert is a key person in the development of this document.

The SOW should include the following:

- Type of renewable energy systems required

- Expected size of systems

- Location on-site

- Specific site requirements

\section{Develop a Notice of Opportunity to} Lease

An NOL is the document issued to the public to solicit offers from fuel cell system developers. This document describes the content to be included in proposals and provides relevant information that developers can use when a making an offer. The NOL should include the following elements.

- Clarification of which party is responsible for procuring permits and arranging contracts for energy generation offtakers

- Commissioning plan

- Criteria used to evaluate proposals 


\section{Steps to Follow}

Identify underutilized land

Develop the scope of work

3 Develop a notice of opportunity to lease

Issue a notice of opportunity to lease

5 Administer the notice of opportunity to lease

6 Evaluate proposals

7 Select a contractor

8 Complete a lease and management plan (contractor submittal)

9 Review and accept the plan

10 Issue the lease

11 Design the project

12 Construct the project

13 Commission the project

14 Monitor the performance period

Perform project close out
- Description of how the proposal process is to be administered (e.g., proposal meetings, site visits, process for answering questions)

- Due diligence

- Limits on proposed project timeline

- Post-commissioning performance

- Proposed financing structure and financial industry commitments

- Scope of work

- Timelines for proposal process

The description of the proposal process administration includes the timing and location of industry forums and site visits, and the process to be used for answering questions. The industry forum provides the opportunity to present the project requirements in detail to interested developers, and for developers to ask questions. The site visit allows interested developers to assess site conditions and ask additional questions. The site visit can be held in conjunction with the industry forum or can be conducted separately. Depending on the site conditions and the process chosen, additional site visits could be necessary for respondents to perform additional due diligence.

Questions that arise during and after the industry forum and site visit must be handled such that all developers have access to the same information. There are many variations on how this can be accomplished. A recommended approach is to write down every question, answer each, and post the questions and answers on a Web site. This process can help to avoid variation in answers, participant misunderstandings, and the potential for one party to receive more information than another.

Describing the criteria and the process to be used to evaluate proposals helps developers structure their responses and ensures that all primary issues are addressed. This also makes it easier to review proposals. The respondents address identified criteria in separate sections, eliminating the need for a reviewer to pick statements from the entire proposal that apply to the criteria. Evaluation criteria should include the considerations that are most important to the specific project, and could include the following.

- In-kind consideration

- Developer's experience, performance track record, and references

- Developer's financial health

- Developer's ongoing, long-term service capacity

- How specific site issues and requirements will be addressed

- Amount of energy generated

- Quality of components

- Local sourcing of components and labor

Describing how to handle due diligence on the developer's part has important contractual 
implications. Due diligence is the effort the developer must put forth to fully understand the project and the risk of any unknowns that could arise. Contractually, the developer wants to have recourse if something unexpected comes up that is outside its ability to perform or that will cause significant cost increases. Under such circumstances, the developer might want to be able to walk away from the project or have the option to renegotiate. Typically, developers should factor the risk into their proposals and be required to deal with the unexpected.

Depending on the project, due diligence could require considerable effort and expense. If this is the case with a project, or if this becomes apparent as the NOL process progresses, consider adding additional steps to the NOL process. Additional steps can include an initial proposal review to generate a short list of developers. Those on the short list are invited to continue with the NOL process, which includes expending additional effort and incurring additional expense for due diligence. The purpose of this extra step is to assure the developers on the short list that they have a good chance at being successful, and that it is worthwhile to put forth the extra effort and expense required for due diligence. A site due diligence date - after which the developer will have entered into an irrevocable contract-should be specified.*

\section{Issue the Notice of Opportunity to Lease}

After the NOL is complete, announce it somewhere that developers can find it.** It should be noted that EULs do not have a traditional RFP process, unlike the agency-funded or PPA procurement mechanisms.

\section{Administer the Notice of Opportunity to Lease}

After the NOL has been issued, follow the defined timeline and described NOL process.

Adjust it as necessary if unforeseen events arise. This step may include site visits, pre-bid meetings, and correspondence related to project questions and answers.

\section{Evaluate the Proposals}

A small team should be assembled to evaluate the offers received. The number of team members to include depends upon the specific project, but the team should have at least three people. Most of the people on this team probably will come from the project team, but other key people may be considered as well:

- Energy manager

- Facilities manager

- Project manager
- Site manager (if managers for different areas of a site)

\section{- Energy systems expert}

The process for evaluating the offers should have been established during the development of the NOL. It is recommended that the proposalevaluation sessions be scheduled well in advance to ensure the availability of key personnel. These review sessions typically take a week unless an unusually large number of proposals (more than 10) is received. Follow the proposal evaluation criteria described in the NOL and, from the start, clearly define the meaning of each criteria and score.

\section{Select the Contractor}

The proposal evaluation scores the offers. This helps determine the most advantageous offer and, consequently, which contractor to select.

\section{Complete a Lease and Management Plan}

Once selected, the contractor and agency initiate steps toward entering into a lease and management plan (L\&MP). The L\&MP describes what the contractor will do and how elements will be completed. An L\&MP can include the following components.

- Architecture and engineering

- Community and stakeholder relations 
- Consultation and coordination in accordance with the Section 106 process as required by the National Historic Preservation Act (NHPA) (if applicable)

- Consultation and coordination with federally recognized Native American tribal governments (if applicable)

- Cultural or archeological documentation

- Financial

- Legal services

- Master planning

- Marketing

- NEPA and other environmental documentation

- Site assessment

The L\&MP is a significant piece of work, and a minimum of 18 months elapses from the time a contractor is selected to the completion of a lease. Prior to completion of L\&MP, all NEPA compliance analysis addressing the proposed project impacts on land within the lease must be completed, through either environmental assessments or environmental impacts studies. The contractor submits the completed L\&MP to the agency.

\section{Review and Accept the Plan}

The completed lease and management plan are reviewed by the agency. If there are any unresolved issues, then last negotiations are completed and the L\&MP is accepted.

\section{Issue the Lease}

After the lease and management plan is accepted, a lease can be finalized and issued. A sample EUL contract can be found at the FEMP Web site.*

\section{Design the Project}

After the contract is awarded, the project final design phase (based on preliminary design work in the L\&MP) begins. The design kickoff should confirm the design parameters for all parties. It is recommended that a qualified, third-party, fuel cell CHP design expert conduct reviews at the $25 \%, 50 \%$, and $100 \%$ design completion, to confirm that site requirements are met. A thorough design review always is faster and less expensive than fixing design flaws later.

\section{Construct the System}

During project construction the primary considerations are in regard to coordinating with the developer. To enable a successful coordination during this phase, first identify a single point of contact. Major areas of coordination include the timing of work (particularly if construction could interfere with the site's mission), ensuring that critical deadlines are met (especially those regarding incentives), assisting with interconnection issues (including interconnection and net metering agreements), and handling incentive applications. The final piece of the construction process is the commissioning of the system-which makes possible the system interconnection and start up.

\section{Commission the System}

When the system is significantly complete and operational, it is recommended that it be commissioned by a third-party expert. This is an important step, as this system is located on the agency's site and system performance can affect the in-kind consideration. A good commissioning ensures that the system has been installed properly and is operating to specifications. It also confirms that there are no apparent safety issues due to poor installation (e.g., damaged wire insulation, unprotected high-voltage connections).

\section{Monitor the Performance Period}

Operation and maintenance of the system is the responsibility of the developer. If in-kind consideration is dependent on the system's energy production, then a process for monitoring energy production should be in place. If the developer owns the RECs produced by the project and the agency must meet renewable energy targets, replacement RECs can be purchased. These RECs can count twice toward the agency's targets as long as the project produces energy at levels greater than or equal to the quantity of RECs purchased. 


\section{Close Out the Project}

The end of the lease options and decisions are characterized by the economic value and viability of the installed system. If the system still can be operated economically then several options can be considered, including extending the lease, purchasing the system for the FMV, or entering into a PPA-type agreement with the developer. If the system has limited or no economic viability at the end of the lease, then it can be abandoned in place or removed. This choice most likely will be influenced by circumstances existing 20 to 75 years in the future, and this should be taken into account when developing the options at the start of the project.

\section{Enhanced Use Lease (EUL)}

\section{PROS}

- Discovers unrealized value of underutilized property.

- Supplements underfunded facilities costs.

- Can be used in combination with the ESPC, UESC, and PPA.

\section{CONS}

- Not all utilities offer UESCs (the FEMP is helping utilities launch UESC programs).

- Currently only DOD, DOE, National Aeronautics and Space Administration (NASA), and the U.S. Department of Veterans Affairs (VA) have the authority to execute an EUL.

- Must not be excess property as defined by 40 U.S.C. § 102. 


\section{Glossary}

This glossary covers words, phrases, and acronyms that are used with fuel cell engines and hydrogen-fueled vehicles. Some words may have different meanings when used in other contexts.

ABSORPTION - The passing of a substance into the body of another substance. For example, a gas being absorbed into a liquid or liquid being absorbed into a solid.

ADSORPTION - The adhesion of the molecules of gases, dissolved substances, or liquids to the surface of the solids or liquids with which they are in contact.

\section{ALTERNATING CURRENT (AC) - A type of}

current that flows from positive to negative and from negative to positive in the same conductor.

ALTERNATIVE FUEL - An alternative to gasoline or diesel fuel that is not produced in a conventional way from crude oil, for example CNG, LPG, LNG, ethanol, methanol, and hydrogen.

ANODE - The electrode at which oxidation (a loss of electrons) takes place. For fuel cells, the anode is electrically negative; for the opposite reaction of electrolysis, the anode is electrically positive.

AROMATICS - Chemical compounds added to natural gas in order to impart odor. Aromatics cannot be added to hydrogen for fuel cell use.
BATTERY - An energy storage device that produces electricity by means of chemical action. It consists of one or more electric cells., each of which has all the chemicals and parts needed to produce an electric current.

BRITISH THERMAL UNITS (Btu) - The quantity of heat required to raise the temperature of one pound of water $1 \stackrel{\circ}{\circ}$. Also Btuh: British thermal units per hour.

\section{CAPACITOR - An energy storage device that} stores electrical energy in the form of an electrical charge. A capacitor consists of two metal plates with an insulating dielectric between them.

CARBON DIOXIDE $\left(\mathrm{CO}_{2}\right)$ - A colorless, odorless gas that results from the complete combustion of carbon with oxygen. Carbon dioxide is a greenhouse gas and is a major contributor to the greenhouse effect.

CATALYST - A substance that can speed or slow a chemical reaction between substances, without itself being consumed by the reaction. Platinum is a typical catalyst in many fuel cell designs.
COOLING SYSTEM - A system that removes heat from engine components by the forced circulation of coolant. Fuel cell engines typically have a bus cooling system and a stack cooling system.

DIRECT CURRENT (DC) - A current that flow through a circuit in one direction only. Direct current voltage is designated VDC.

EFFICIENCY - The ratio between an actual result and the theoretically possible result.

EFFICIENCY, THERMAL - The ratio of the energy output of an engine to the energy in the fuel required to produce that output.

EFFICIENCY, SYSTEM (OR OVERALL) - The ratio of the useable work that results from some series of processes to the total amount of energy used during those processes.

ELECTROLYSIS - The decomposition water into its elemental components (hydrogen and oxygen) through the application of electrical energy.

ENERGY CONTENT - Amount of energy for a given weight of fuel. Every fuel can liberate a fixed amount of energy when it reacts completely with oxygen to form water. This energy content 
is measured experimentally and is quantified by a fuel's higher heating value (HHV) and lower heating value (LHV). The difference between the HHV and the LHV is the "heat of vaporization" and represents the amount of energy required to vaporize a liquid fuel into a gaseous fuel, as well as the energy used to convert water to steam.

ENERGY DENSITY - Amount of energy for a given volume of fuel. Thus, energy density is the product of the energy content and the density of a given fuel.

ENGINE - A machine that converts heat energy into mechanical energy.

FUEL - A substance that releases energy when reacted chemically with oxygen.

HEAT - A form of energy that is released by the burning of fuel. In an engine, heat energy is converted to mechanical energy.

HYDROCARBON (HC) - An organic compound containing only carbon and hydrogen, usually derived from fossil fuels such as petroleum, natural gas, and coal: an agent in the formation of photochemical smog.

HYDROGEN $\left(\mathrm{H}_{2}\right)$ - The simplest and lightest element in the universe, which exists as a gas except at low cryogenic temperatures. Hydrogen gas is colorless, odorless, and highly flammable gas when mixed with oxygen over a wide range of concentrations. Hydrogen forms water when combusted, or when otherwise joined with air, as within a fuel cell.
INTERNAL COMBUSTION ENGINE (ICE) - An engine in which the fuel is burned inside the engine itself, rather than in a separate device, such as a boiler on a steam engine.

KELVIN - Metric scale of absolute temperature (K).

KILOWATT (kW) - A unit of power equal to about $1.34 \mathrm{hp}$, or 1,000 watts

LEAN MIXTURE - An air-fuel mixture that has a relatively low proportion of fuel in relation to air. For example, an air-fuel ratio of 16:1 indicates a lean mixture, compared to an approximately normal air fuel ratio of 14.7:1 for gasoline.

LIQUEFIED NATURAL GAS (LNG) - A motor fuel composed of natural gas that has been liquefied. Liquefied natural gas cooled to $111 \mathrm{~K}(-259$ \% ; $-162^{\circ} \mathrm{C}$ ) and ambient pressure becomes a liquid.

NATURAL GAS - Mixtures of hydrocarbon gases and vapors consisting principally of methane in gaseous form.

ODORIZATION - A process of adding a distinctive odor to natural gas so that its presence can be easily detected.

\section{OEM - Original Equipment Manufacturer}

OXIDATION - Burning or combusting; the combining of material with oxygen. Rusting is slow oxidation, and combustion is rapid oxidation.

OXYGEN $\left(\mathrm{O}_{2}\right)$ - A colorless, tasteless, odorless, gaseous element that makes up about $21 \%$ of air. Oxygen is capable of combining rapidly with ALL elements (except inert gases) in the oxidation process called burning (combustion). Oxygen combines very slowly with many metals in the oxidizing process called rusting.

ppm - Parts per million

REFORMING - A chemical process that reacts hydrogen-containing fuels in the presence of steam, oxygen, or both into a hydrogen-rich gas stream.

SPECIFIC GRAVITY - Ratio of the weight of the gas to the weight of air or the ratio of the weight of a liquid to an equal volume of pure water.

SPECIFIC HEAT - Ratio of the amount of heat required to raise the gas temperature one degree compared to the amount of heat required to raise an equal amount of water one degree.

STANDARD CONDITIONS - Temperature and pressure conditions that cor-respond to $0^{\circ} \mathrm{C}$ (32 ${ }^{\circ}$ ) and 14.7 psig (1 barg) respectively. Sometimes, standard temperature is taken as room temperature. STP - Standard temperature and pressure.

STIRLING ENGINE - A type of internal combustion engine in which the piston is moved by changes in the pressure of a working gas that is alternately heated and cooled. It has two isothermal processes and two constant-volume processes. 
STOICHIOMETRIC (STOICH) - A chemically perfect reaction of fuel and air in an engine (the only products of combustion are water and carbon dioxide).

STOICHIOMETRIC AIR-FUEL RATIO - The exact air-fuel ratio required to completely react a fuel into water and carbon dioxide.

SULFUR OXIDES (SOx) - Acids that can form in small amounts as the result of a reaction between hot exhaust gas and the catalyst in a catalytic converter.

THERMAL EFFICIENCY - The ratio of the energy output of an engine to the energy in the fuel required to produce that output.

TRANSDUCER - Any device that converts an input signal of one form into an output signal of a different form.

VENTING - The discharge of hydrogen from a fuel storage system to the atmosphere. 


\section{Appendix A: Fuel Cell Technologies Overview}

There are five basic fuel cell types under consideration for DG applications. The fuel cell's electrolyte or ion conduction material defines the basic type. Two of these fuel cell types, polymer electrolyte membrane (PEM) and phosphoric acid fuel cell (PAFC), have acidic electrolytes and rely on the transport of $\mathrm{H}+$ ions. Two others, alkaline fuel cell (AFC) and carbonate fuel cell (MCFC), have basic electrolytes that rely on the transport of $\mathrm{OH}^{-}$and $\mathrm{CO}_{3}{ }^{2}$-ions, respectively. The fifth type, solid oxide fuel cell (SOFC), is based on a solid-state ceramic electrolyte in which oxygen ions $\left(\mathrm{O}^{2-}\right)$ are the conductive transport ion.

Each fuel cell type operates at optimum temperature, which is a balance between the ionic conductivity and component stability. These temperatures differ significantly among the five basic types, ranging from near ambient to as high as $1,000^{\circ} \mathrm{F}$. The proton-conducting fuel cell type generates water at the cathode and the anion-conducting fuel cell type generates water at the anode.

Table 1. Technology Characterization Fuel Cells

\begin{tabular}{|c|c|c|c|}
\hline & PAFC & MCFC & SOFC \\
\hline Type of Electrolyte & $\begin{array}{l}\mathrm{H}+\text { ions }\left(\mathrm{H}_{3} \mathrm{PO}_{4}\right. \\
\text { solutions) }\end{array}$ & $\begin{array}{l}\mathrm{CO}_{3}=\text { ions (typically, } \\
\text { molten } \mathrm{LiKaCO}_{3} \\
\text { eutectics) }\end{array}$ & $\begin{array}{l}\mathrm{O}=\text { ions (Stabilized } \\
\text { ceramic matrix with } \\
\text { free oxide ions) }\end{array}$ \\
\hline Typical construction & $\begin{array}{l}\text { Carbon, porous } \\
\text { ceramics }\end{array}$ & $\begin{array}{l}\text { High temp metals, } \\
\text { porous ceramic }\end{array}$ & $\begin{array}{l}\text { Ceramic, high temp } \\
\text { metals }\end{array}$ \\
\hline Internal reforming & No & Yes, good temp match & Yes, good temp match \\
\hline Oxidant & Air to enriched air & Air & Air \\
\hline Operational Temperature & $130-200^{\circ} \mathrm{C}$ & $600-700^{\circ} \mathrm{C}$ & $500-1,000^{\circ} \mathrm{C}$ \\
\hline $\begin{array}{l}\text { DG System Level } \\
\text { Efficiency, percent LHV }\end{array}$ & 31 to $41 \%$ & 36 to $45 \%$ & 40 to $60 \%$ \\
\hline $\begin{array}{l}\text { Primary Contaminate } \\
\text { Sensitivities }\end{array}$ & CO $<1 \%$, Sulfur & Sulfur & Sulfur \\
\hline
\end{tabular}

Table 1 lists the basic characteristics for the three most common fuel cell types.

\section{PAFC (Phosphoric Acid Fuel Cell)}

PAFCs use phosphoric acid as the electrolyte and are generally considered the most established fuel cell technology. The first PAFC DG system was designed and demonstrated in the early 1970s. PAFCs are capable of fuel-toelectricity efficiencies of 40 percent LHV or greater. A $200 \mathrm{~kW}$ PAFC has been commercially available since the early $1990 \mathrm{~s}$. The current 400 $\mathrm{kW}$ product has a stack lifetime of over 80,000 hours and commercially based reliabilities of around 95 percent.*

\section{MCFC (Molten Carbonate Fuel Cell)}

MCFCs are high-temperature fuel cells with certain advantages in CHP applications. These fuel cells have internal operating temperatures of $600^{\circ} \mathrm{F}$ to $700^{\circ} \mathrm{F}$, which facilitates internal reforming of natural gas within the fuel stack. MCFC processes fuel outside of the stack as well. MCFC can achieve efficiencies of $47 \%$ LHV efficiency.

MCFC systems use an electrolyte composed of a molten mixture of alkali metal carbonate salts. 
Operating at temperatures around $50^{\circ} \mathrm{C}$, ions $\left(\mathrm{CO}_{3}{ }^{2-}\right)$ within the carbonate salts are highly mobile. The ions move from the cathode to the anode where they combine with hydrogen to produce water $\left(\mathrm{H}_{2} \mathrm{O}\right)$, carbon dioxide $\left(\mathrm{CO}_{2}\right)$, and electrons (e). The electrons form the external current flow that provides the electrical output of the fuel cell. The returning electrons flow to the cathode, completing the circuit and generating heat.

Anode reaction:

$\mathrm{CO}_{3}{ }^{2-}+\mathrm{H}_{2}=>\mathrm{H}_{2} \mathrm{O}+\mathrm{CO}_{2}+2 \mathrm{e}^{-}$

Cathode reaction:

$\mathrm{CO}_{2}+1 / 2 \mathrm{O}_{2}+2 \mathrm{e}-=>\mathrm{CO}_{3}^{2-}$

There are several advantages to the MCFC when compared to the lower temperature PAFC. The major advantage is that the reforming of natural gas occurs within the fuel cell stack.

MCFC processes fuel outside of the stack as well. Another advantage of the MCFC is the use of standard metals such as stainless steel sheet and nickel-based catalysts on the electrodes. The higher temperature of the MCFC also allows for the generation of high pressure steam. The MCFC's operation at higher temperatures is best applied in constant power output applications.*

\section{SOFC (Solid Oxide Fuel Cell)}

The SOFC uses solid, nonporous metals oxide electrolytes and is generally considered less mature in its development than the MCFC and PAFC technologies. Several SOFC units up to $100 \mathrm{~kW}$ in size and based on a concentric tubular design have been built and tested. In addition, there are many companies developing planar SOFC designs, which offer higher power densities and lower costs than the tubular design; however, these planer designs tend to have lower reliability and durability than tubular systems.

The high electrical efficiency and high quality heat provided by the $\mathrm{SOFC}$ has attracted development support. The SOFC has projected electric efficiencies of 50 to 60 percent. Efficiency can be even higher $(\sim 70 \%)$ in larger hybrid, combined cycle plants.** Efficiencies for smaller SOFC DG units are currently around $40 \%$.***

In an SOFC, a reaction occurs on the surface of the cathode to generate oxide ions that migrate through the electrolyte to the anode. Fuel containing hydrogen reacts with the oxide ions at the anode to produce water and electrons. The freed electrons travel through the electrical circuit to the cathode, creating direct current electricity.

\section{Cathode reaction:}

$\mathrm{O}_{2}+4 \mathrm{e}-=>2 \mathrm{O}^{2-}$

Anode reaction:

$2 \mathrm{O}^{2-}+2 \mathrm{H}_{2}=>2 \mathrm{H}_{2} \mathrm{O}+4 \mathrm{e}^{-}$

The high internal temperatures of the SOFC make internal reforming possible. However, these high temperatures add to materials and mechanical design challenges.

* http://www.fuelcellenergy.com/dfc1500ma.php

** http://www.fossil.energy.gov/programs/powersystems/fuelcells/fuelcells_solidoxide.html

*** http://www1.eere.energy.gov/hydrogenandfuelcells/annual_reports.html 


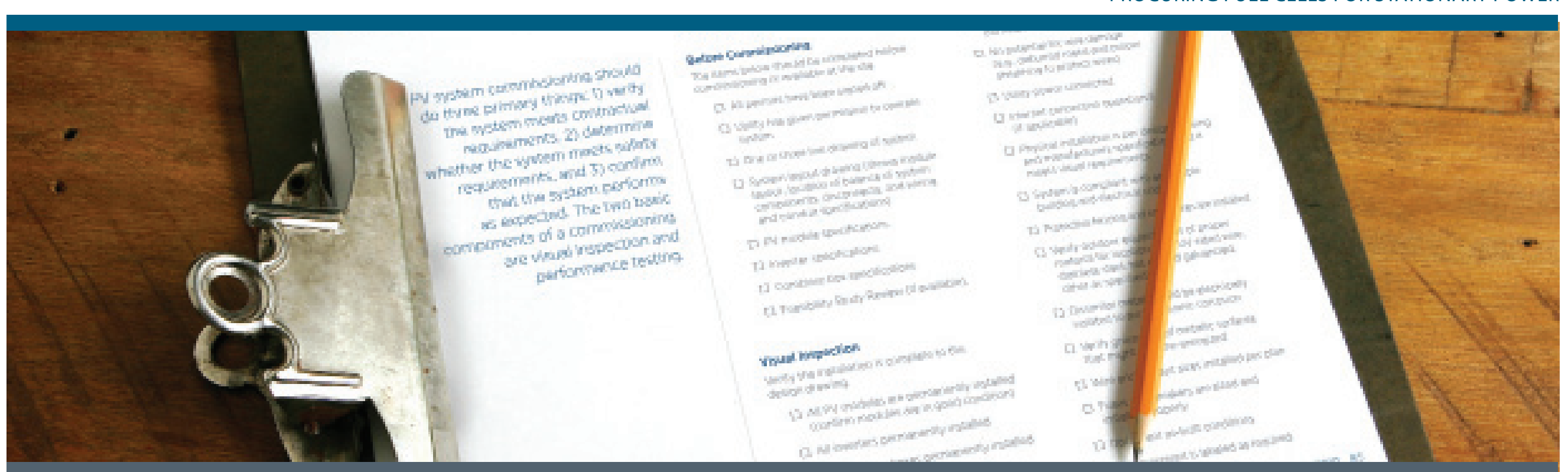

\section{Appendix B: Screening Calculations, \& Checklists}

One common measure for evaluating the cost of a CHP system is the Cost of Electricity (COE). The COE calculation produces the effective cost of generating power from the CHP system. This allows a quick comparison to the cost of purchased power.

Figure $\mathrm{B}$ shows a COE calculation based on the procedure from the EPA CHP Partnership. The assumptions and results are just an example based on common inputs. Site-specific information is necessary to obtain useful results.

In the example, the installed cost of the fuel cell CHP is assumed to be $\$ 4,600$ per $\mathrm{kW}$ or $\$ 1.38$ million for a $300 \mathrm{~kW}$ system. The project is assumed to be eligible for incentives totalling $\$ 2,500$ per $\mathrm{kW}$, substantially reducing the capital investment. The cost of purchased natural gas is $\$ 8.48$ per MMBtu, which is a typical rate for a commercial facility. The fuel cell is assumed to have a $40 \%$ electricity efficiency.

The results of this example analysis show the total COE to be $\$ 0.132$ per $\mathrm{kWh}$ or 13.2 cents per $\mathrm{kWh}$. This cost includes $\$ 0.030$ for recovery of the initial capital investment, $\$ 0.072$ for the natural gas consumed in the fuel cell, $\$ 0.020$ for O\&M and $\$ 0.009$ to fund the stack replacement reserve. The cost for natural gas represents $55 \%$ of the COE.

Because this is a CHP system, the COE must be adjusted to account for the value of the thermal energy generated by the fuel cell. In this example, the useful thermal energy (e.g., steam or hot water) generated by the fuel cell is assumed to displace production of a typical boiler with an efficiency of $80 \%$. The value of this useful thermal energy is $\$ 0.0118$ per $\mathrm{kWh}$, which reduces the net COE to $\$ 0.114$ per kWh. 


\section{Screening Calculations}

Primary Assumptions

\begin{tabular}{r|l}
\hline 300 & kW fuel cell CHP system \\
0.51 & MMBtu per hour useful thermal \\
$40 \%$ & Electricity-only generating efficiency (without thermal credit) \\
8.500 & Hours per year of operation \\
$\$ 4,600$ & Purchased CHP System Cost $(\$ / k W)$ \\
$\$ 2,500$ & Incentive $(\$ / k W)$ \\
$\$ 800$ & Cost of stack replacement $(\$ / k W)$ \\
10 & Stack life (years) \\
$\$ 0.020$ & per kWh Operating and Maintenance Cost for CHP system \\
$\$ 8.481$ & per MMBtu cost of natural gas used in CHP system \\
$7 \%$ & Interest Rate $(\%)$ \\
12 & Financed Life of project (years)
\end{tabular}

\section{Cost of Electricity}

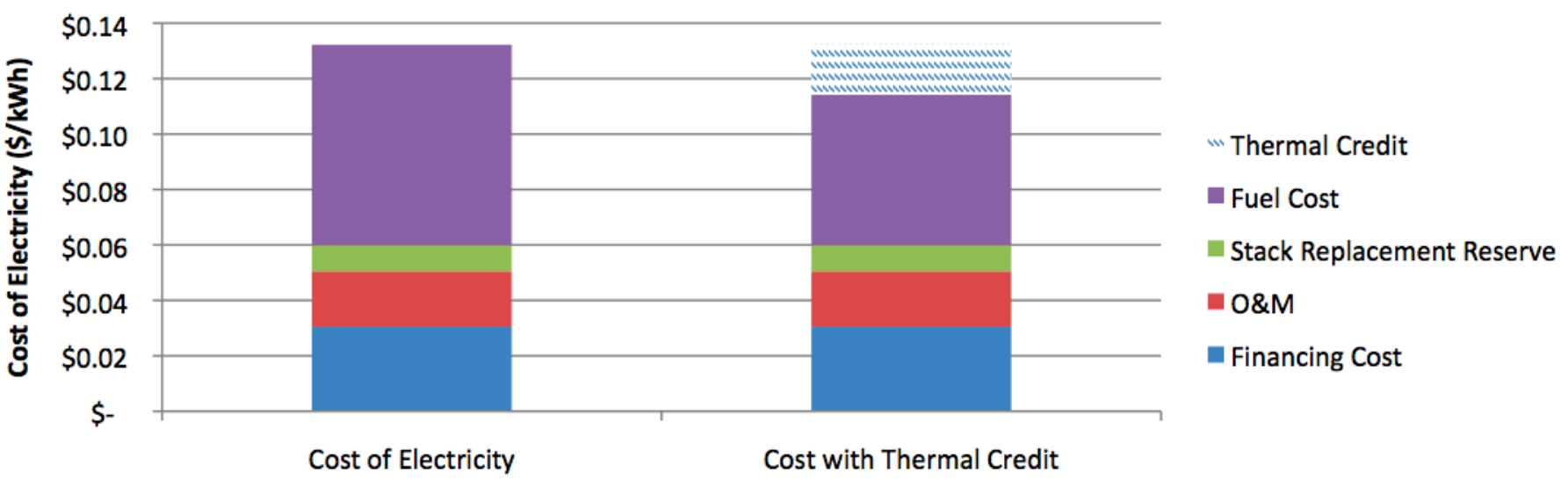

$\$ 0.072$ Fuel Cost
Cost of Electricity Analysis (Cost: \$ per kW)

$\$ 0.030$ Financing Cost

$\$ 0.020$ O\&M

$\$ 0.009$ Stack Replacement Reserve

$\$ 0.132$ Total Annual Cost without Thermal Credit

$\$(0.018) \quad$ Thermal Credit

\$0.114 Annual Cost with Thermal Credit 


\section{Checklist: Facility Energy Data Collection Sheet}

The Industrial Technologies Program (ITP) ${ }^{1}$ leads DOE's national CHP effort, which includes a robust portfolio of technology research and development, demonstrations, and market transformation initiatives. The ITP Web site includes useful information on understanding CHP technology as well as guidance on the technical analysis and detailed planning for new project. ${ }^{2}$

An important resource from the ITP Web site is a data collection sheet suitable for an analysis of a facility's suitability for a CHP project. The data collection sheet can be used for almost any CHP technology and is appropriate for evaluating fuel cell systems. ${ }^{3}$

(* indicates data required for the step one Walk-through Analysis, other information is useful for the step two Feasibility Analysis)

\section{ELECTRICAL REQUIREMENTS}

- Average demand during operating hours* kW (kilowatt)

- Minimum demand during operating hours $\mathrm{kW}$

- Peak demand during operating hours

- Annual electricity consumption $\mathrm{kW}$

THERMAL REQUIREMENTS

- Form of thermal energy use* steam hot water cooling other (specify)

- What is the primary application for thermal energy at the plant?*

- Average demand during operating hours* $\mathrm{lbs} / \mathrm{hr}$ (pounds per hour), Btu/hr (British thermal units per hour), Btu fuel $/ \mathrm{hr}$ (circle correct units)

- Minimum demand during operating hours $\mathrm{lbs} / \mathrm{hr}, \mathrm{Btu} / \mathrm{hr}, \mathrm{Btu}$ fuel $/ \mathrm{hr}$

- Peak demand during operating hours $\mathrm{lbs} / \mathrm{hr}, \mathrm{Btu} / \mathrm{hr}$, Btu fuel/hr

- Required conditions* $\mathrm{lbs} / \mathrm{hr}, \mathrm{Btu} / \mathrm{hr}, \mathrm{Btu}$ fuel/hr

\section{OPERATING CONDITIONS}

- Nominal operating hours per year* hours per year

- Number of hours per year that electrical and thermal loads are simultaneously at or above average values* hours per year

Note that ITP is being reorganized to focus on industrial manufacturing processes and will be renamed the Advanced Manufacturing Office. 


\section{ENERGY RATES}

- Average retail electric rate* cents/kWh

- Tariff rate (electric)* cents/kWh

- Tariff rate (natural gas)* cents/kWh

- Peak demand charge (if applicable) $\$ / \mathrm{kW} / \mathrm{month}$

- Fuel price* __ \$ _ _mmBtu (dollars per million British thermal unit), \$/therm, \$/gal (dollars per gallon) (circle appropriate units) SITE CONDITIONS

- Is there sufficient floorspace (inside or outside for a CHP installation)?* Yes No

- Is adequate fuel accessible/available for a CHP installation?* Yes

- Are there specific environmental or zoning restrictions that may preclude a CHP installation?* Yes No 


\section{Appendix C: DOE Fuel Cell Financing for Tax-Exempt Entities}

The following fact sheet describes how fuel cell deployments are facilitated by structuring energy service contracts to include the Energy Investment Tax Credit. 


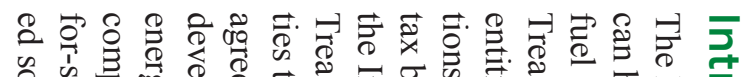

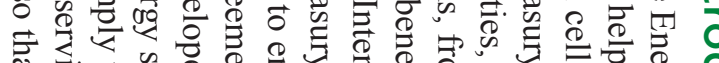

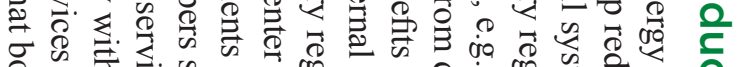

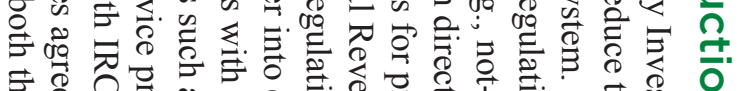

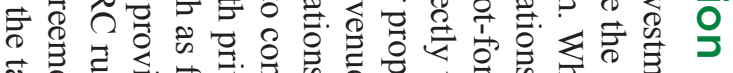

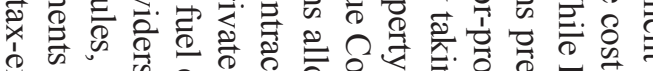

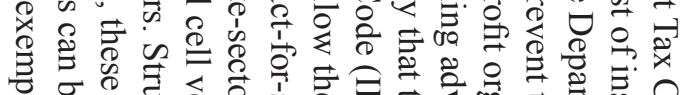

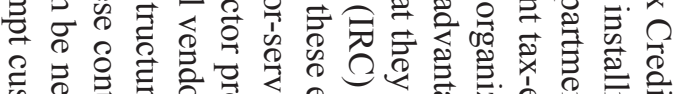

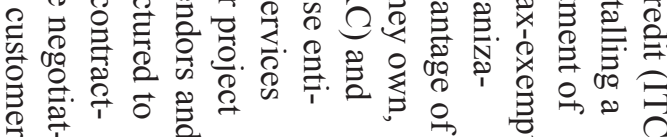
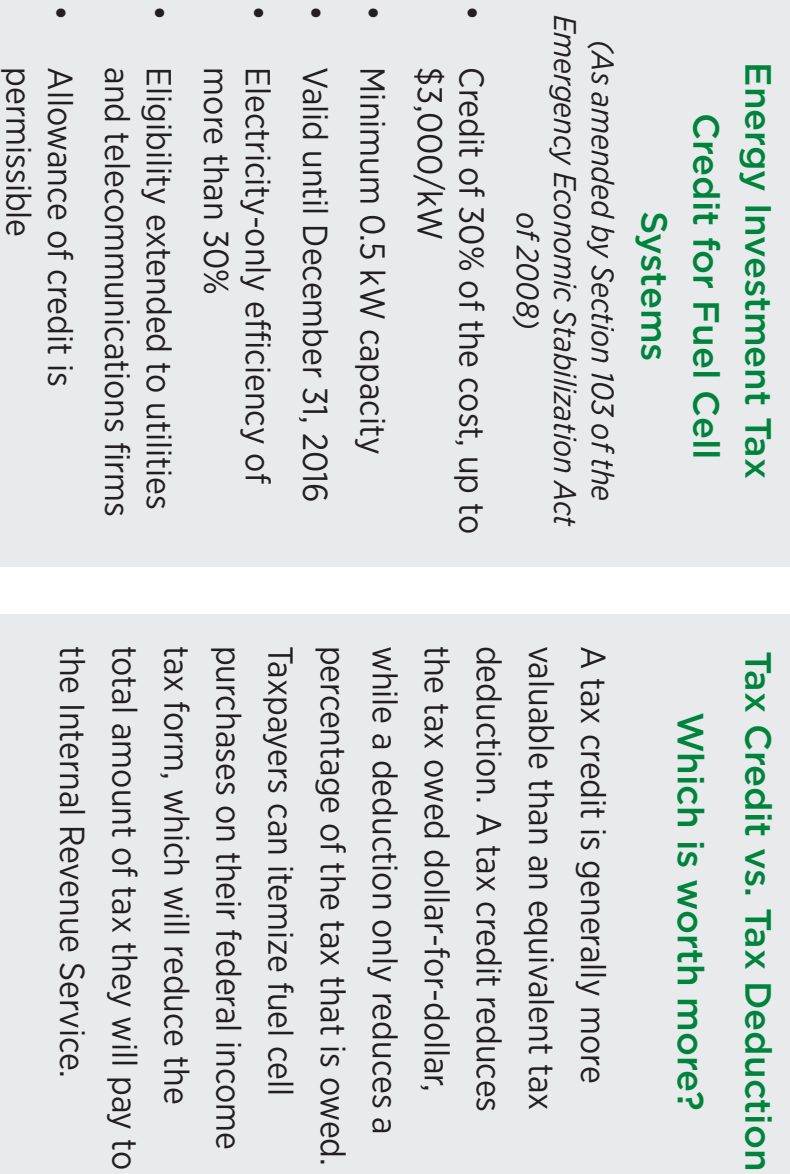
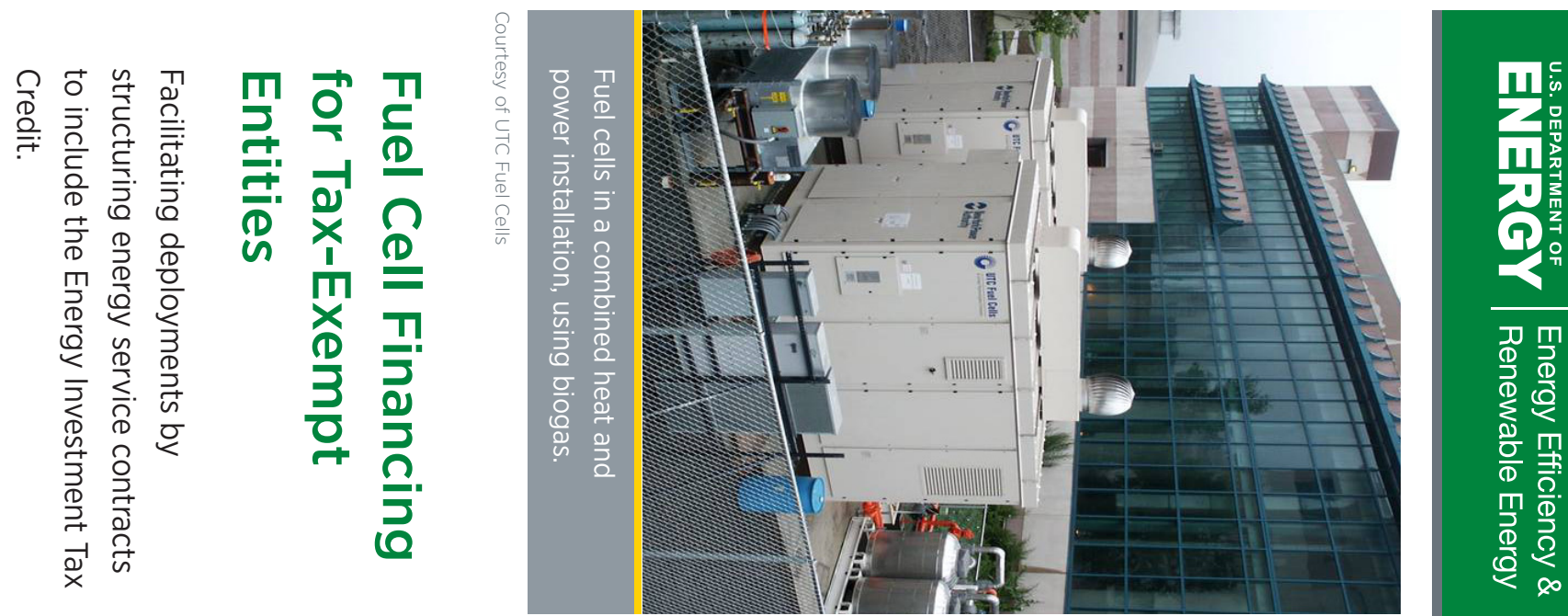

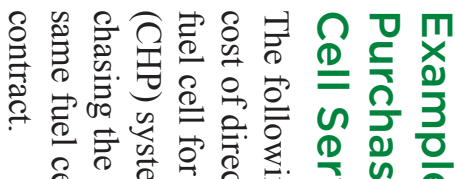

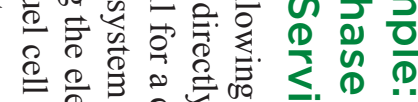

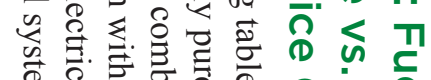

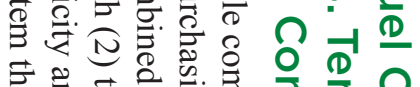

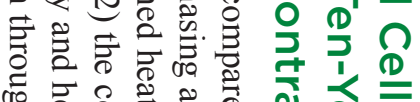

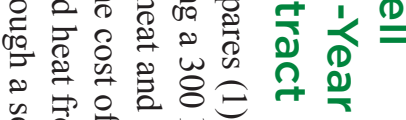

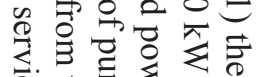
ำ

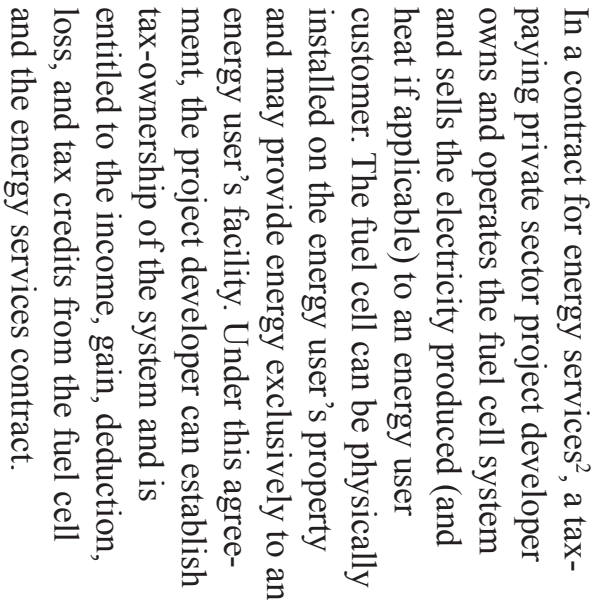

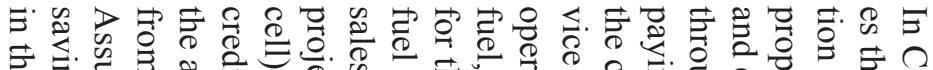

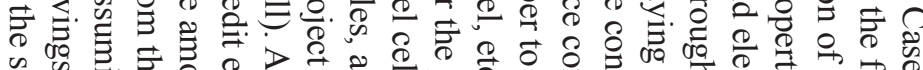

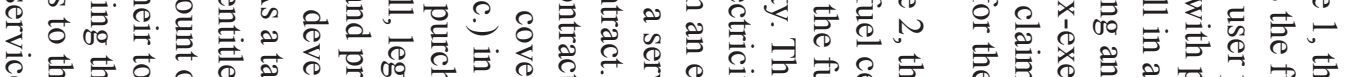

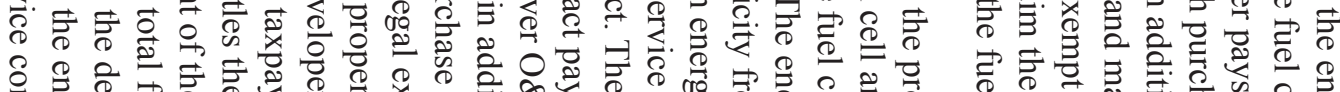

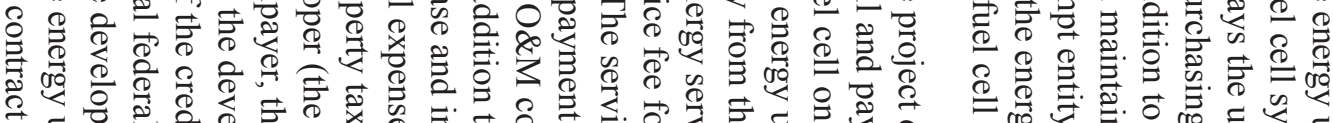

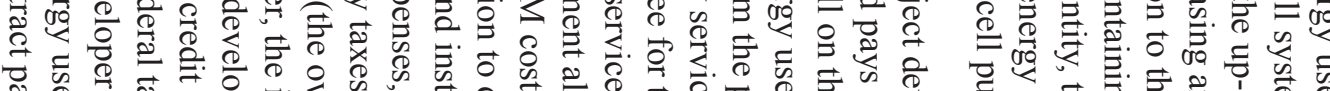

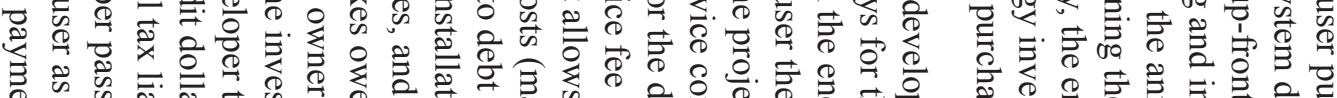

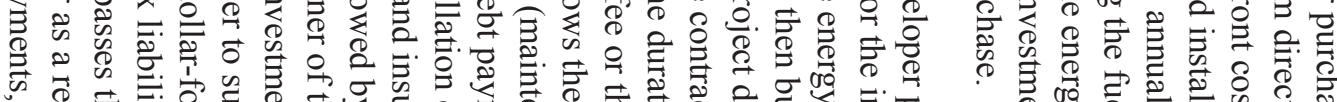

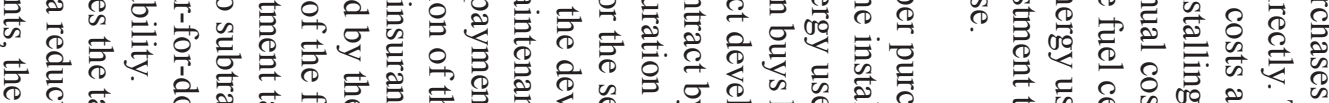

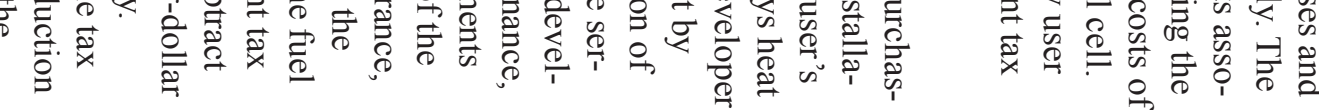




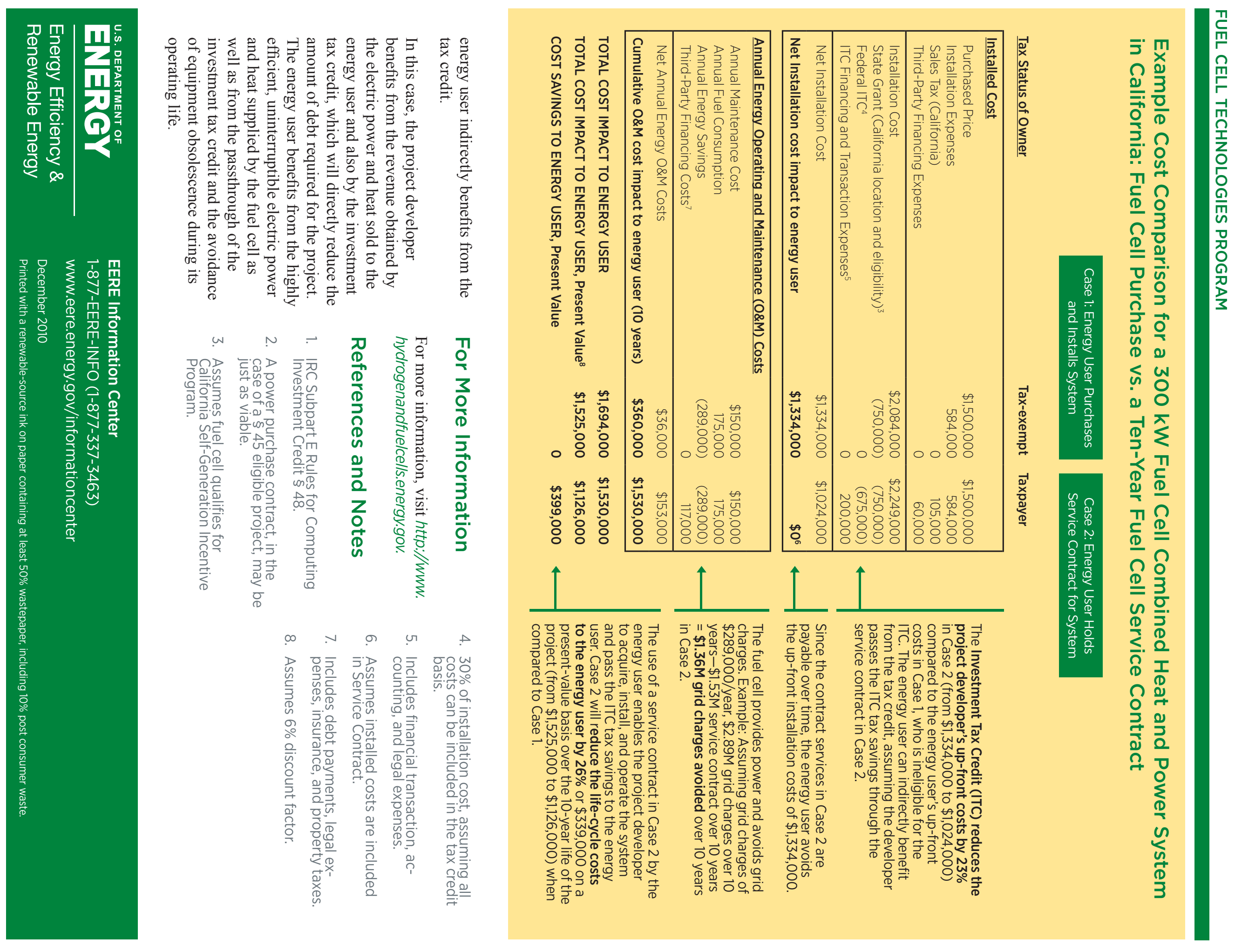




\section{Appendix D: Fact Sheets for Fuel Cell CHP Projects}

The following fact sheets describe successful commercial fuel cell CHP installations in the United States. 

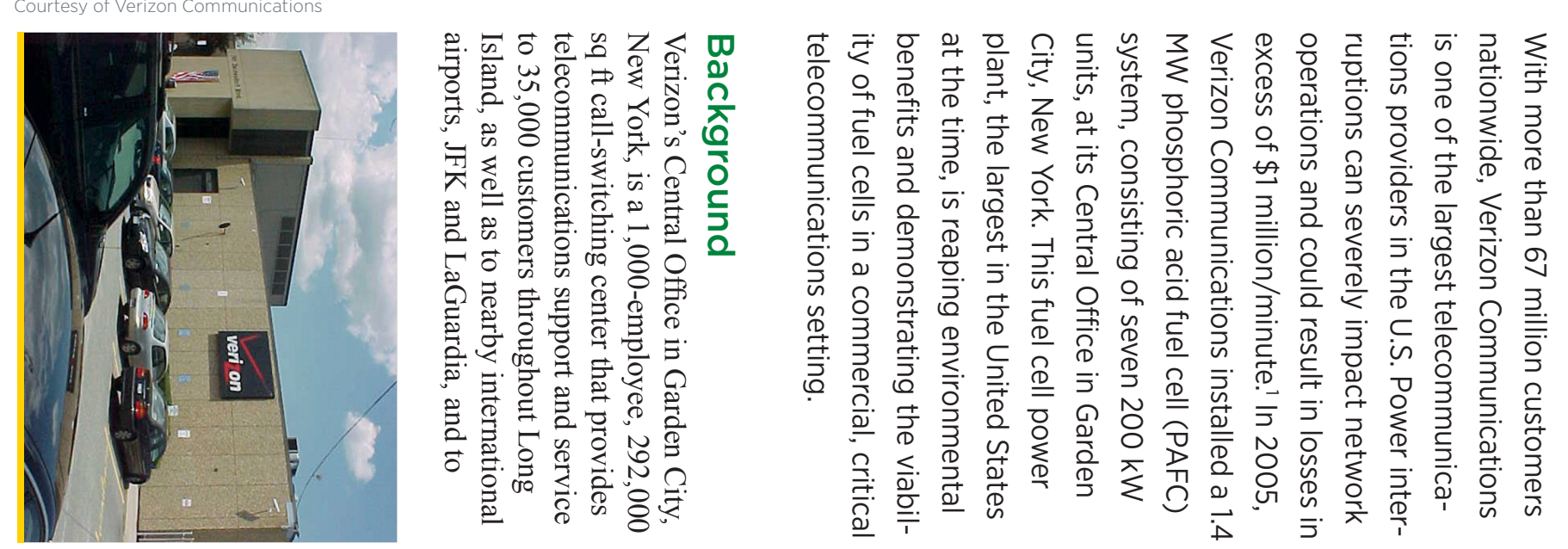

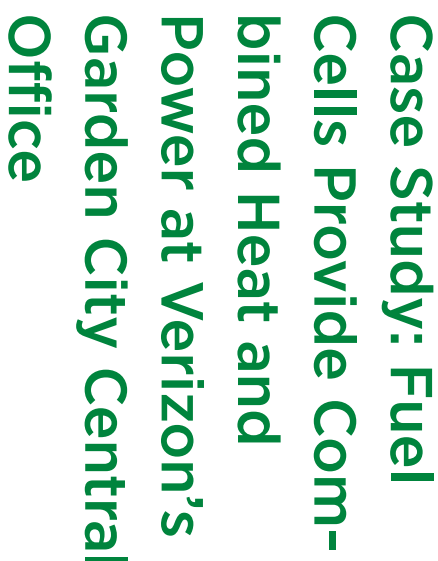

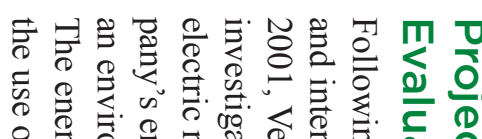

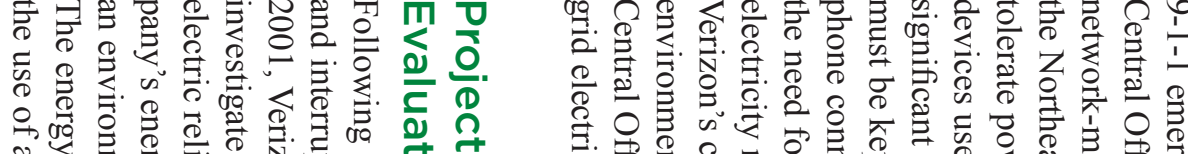

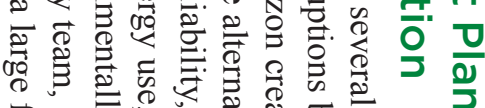

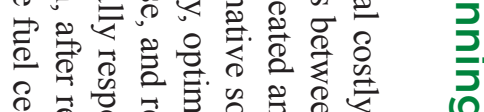

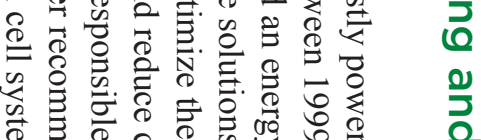

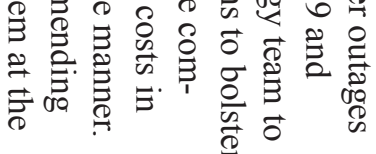
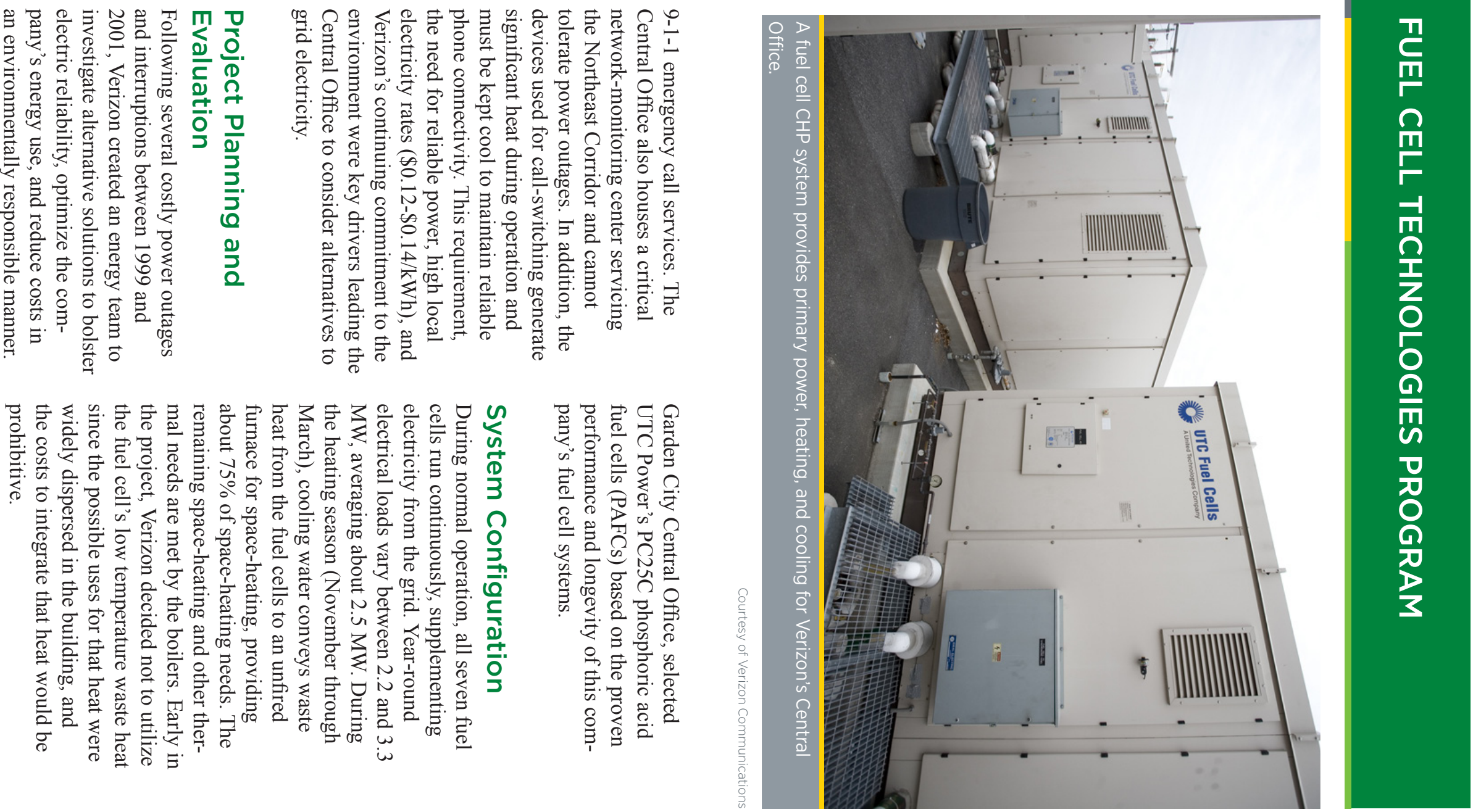


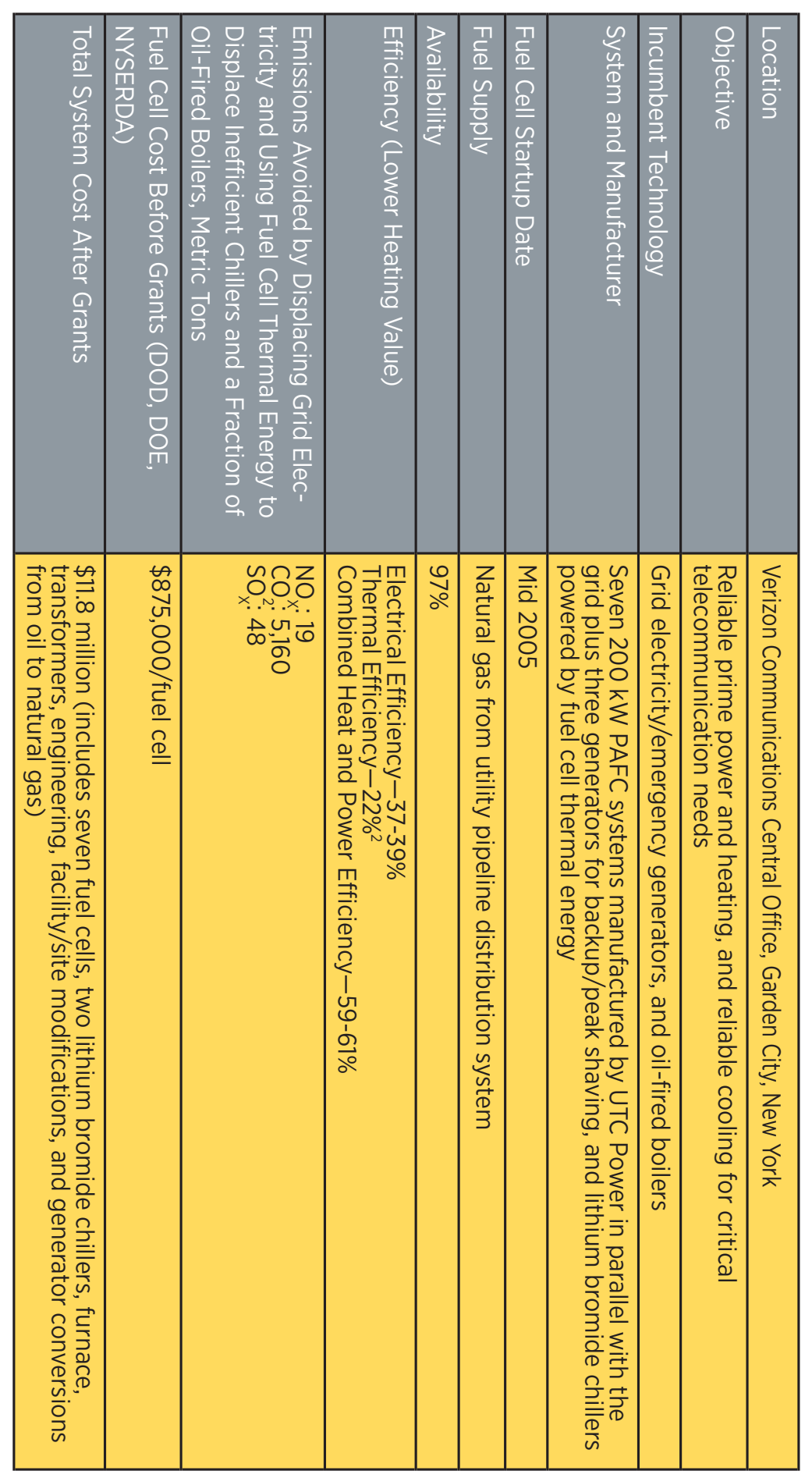

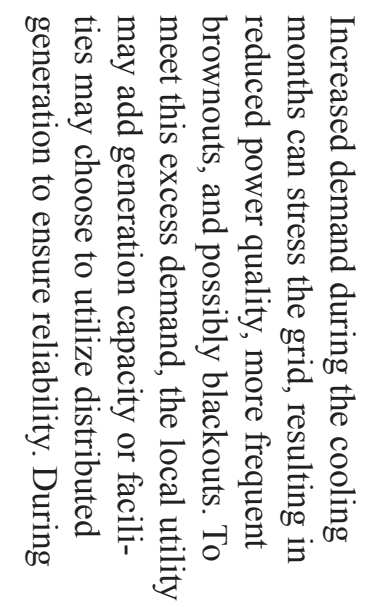

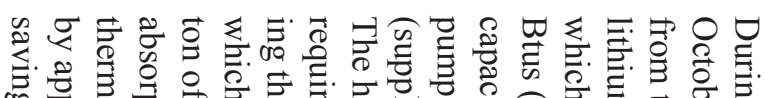

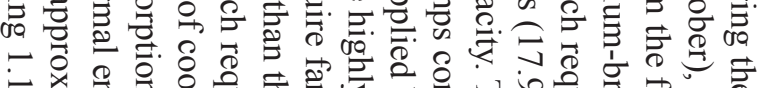

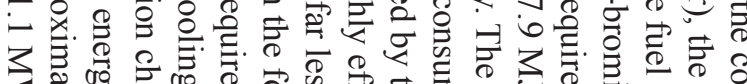

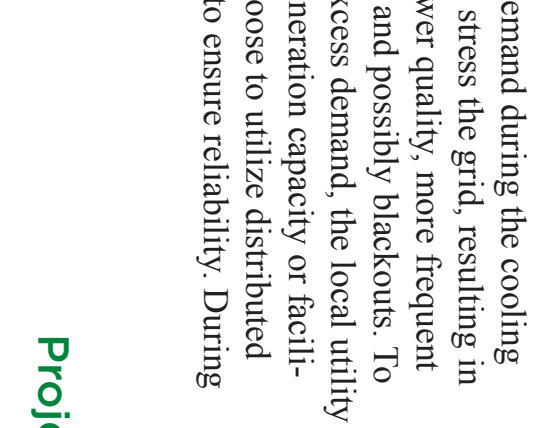

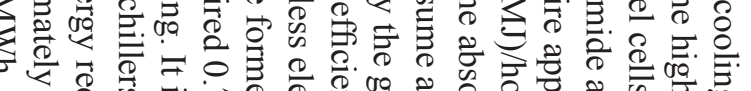

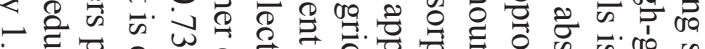

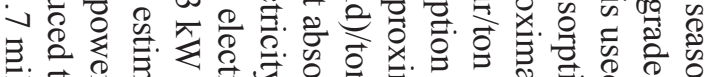

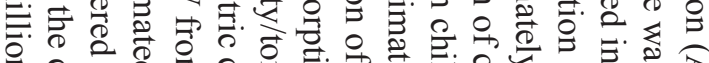

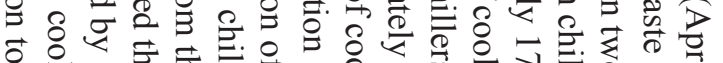

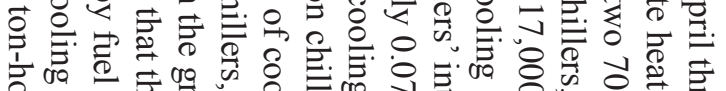

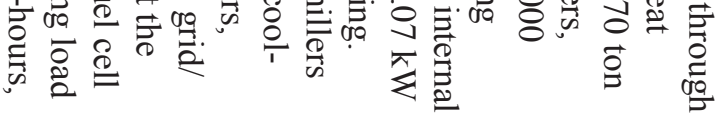

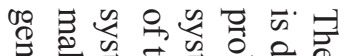

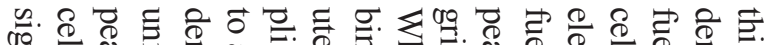

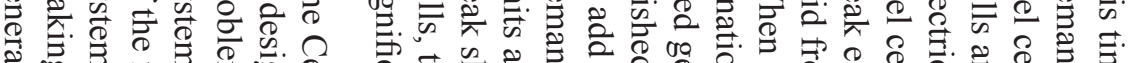

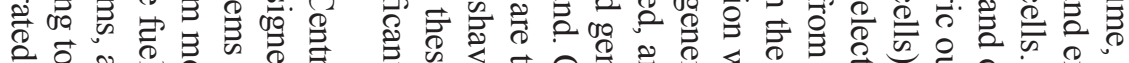

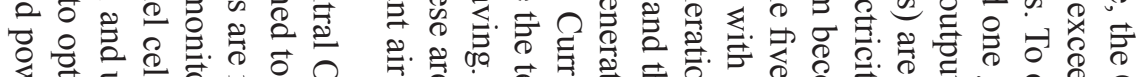

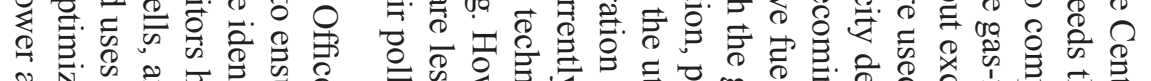

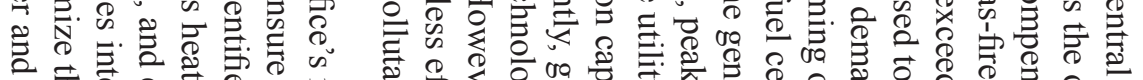

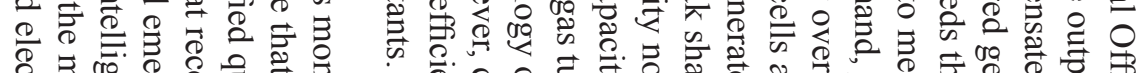

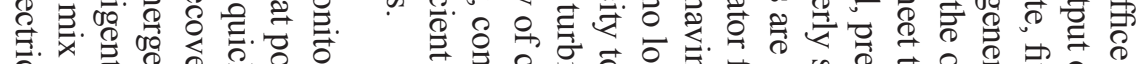

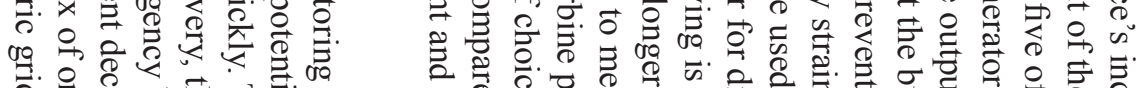

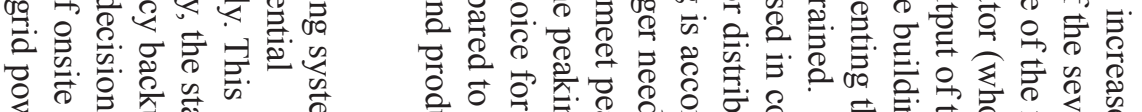

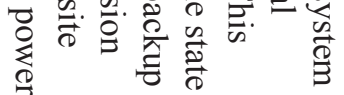

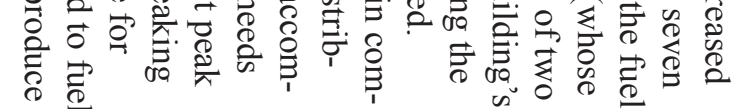
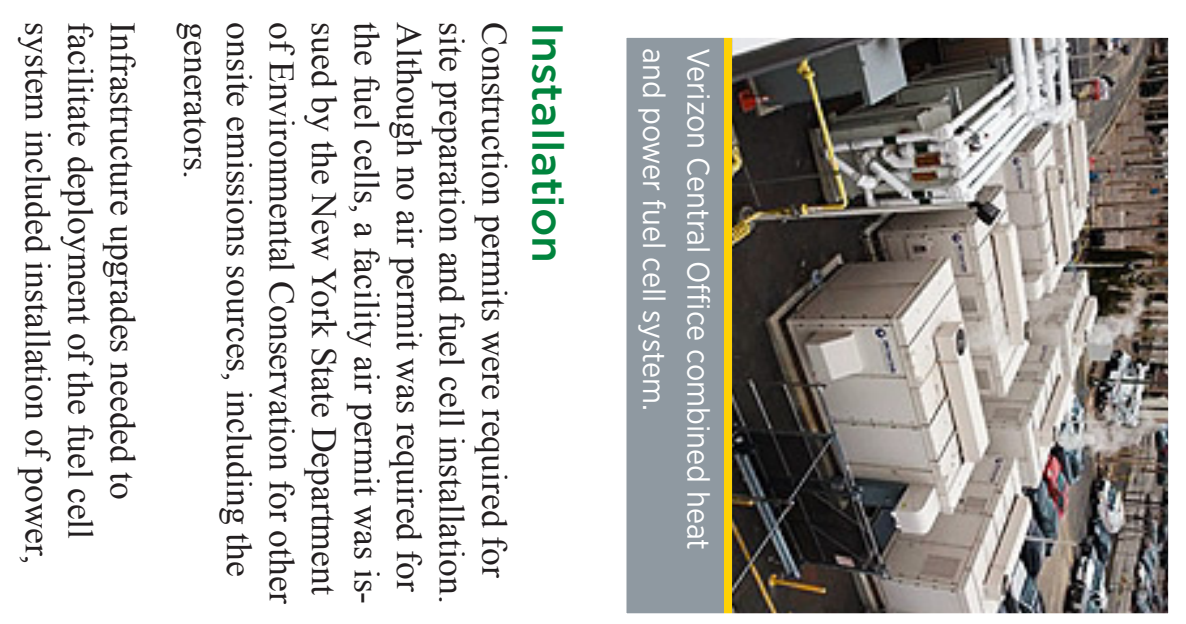

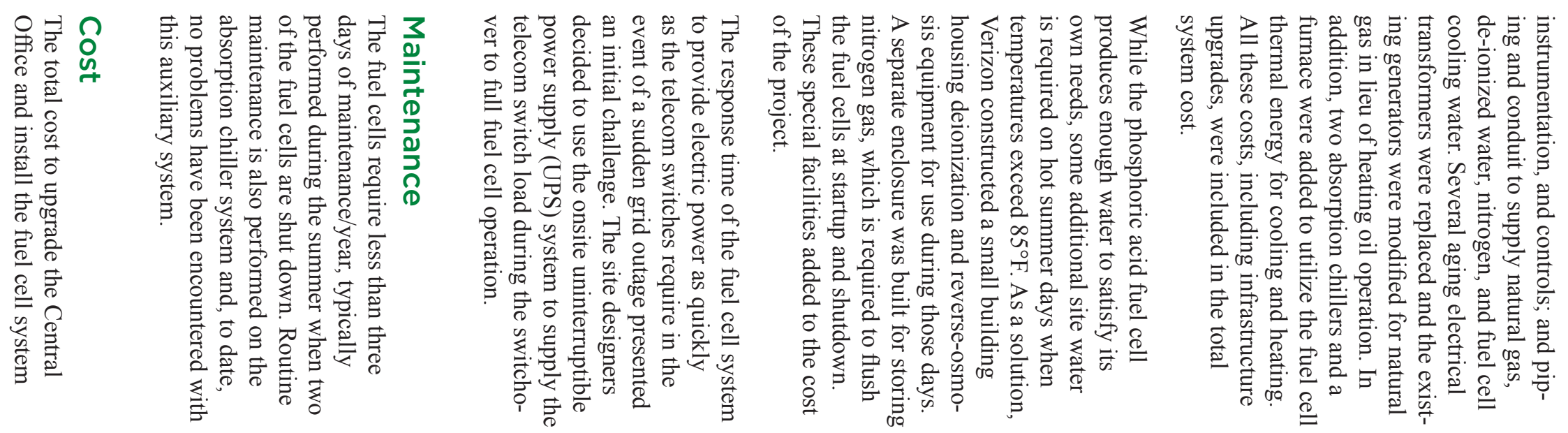

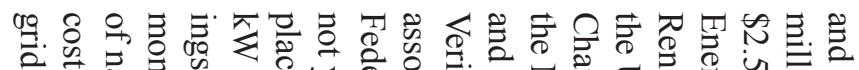

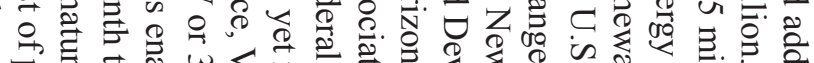

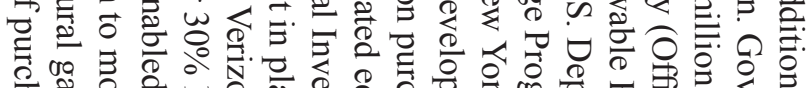

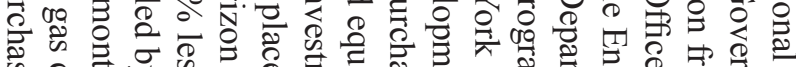

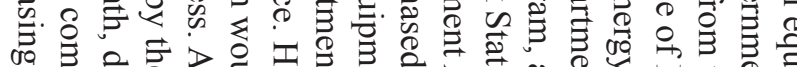

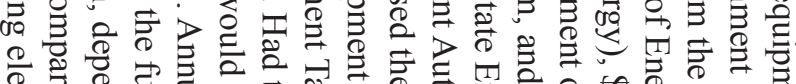

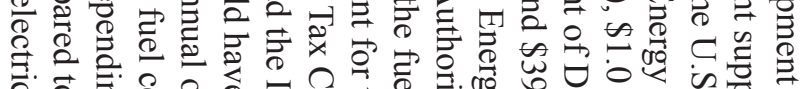

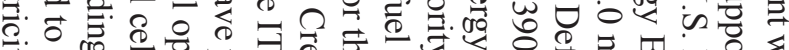

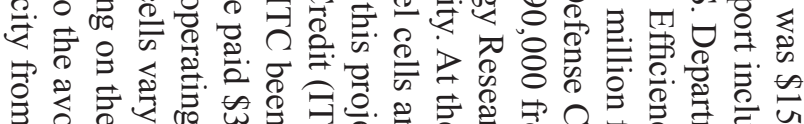

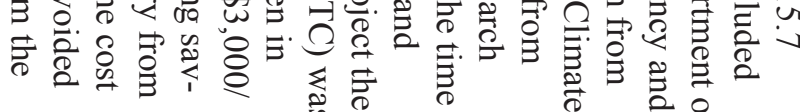
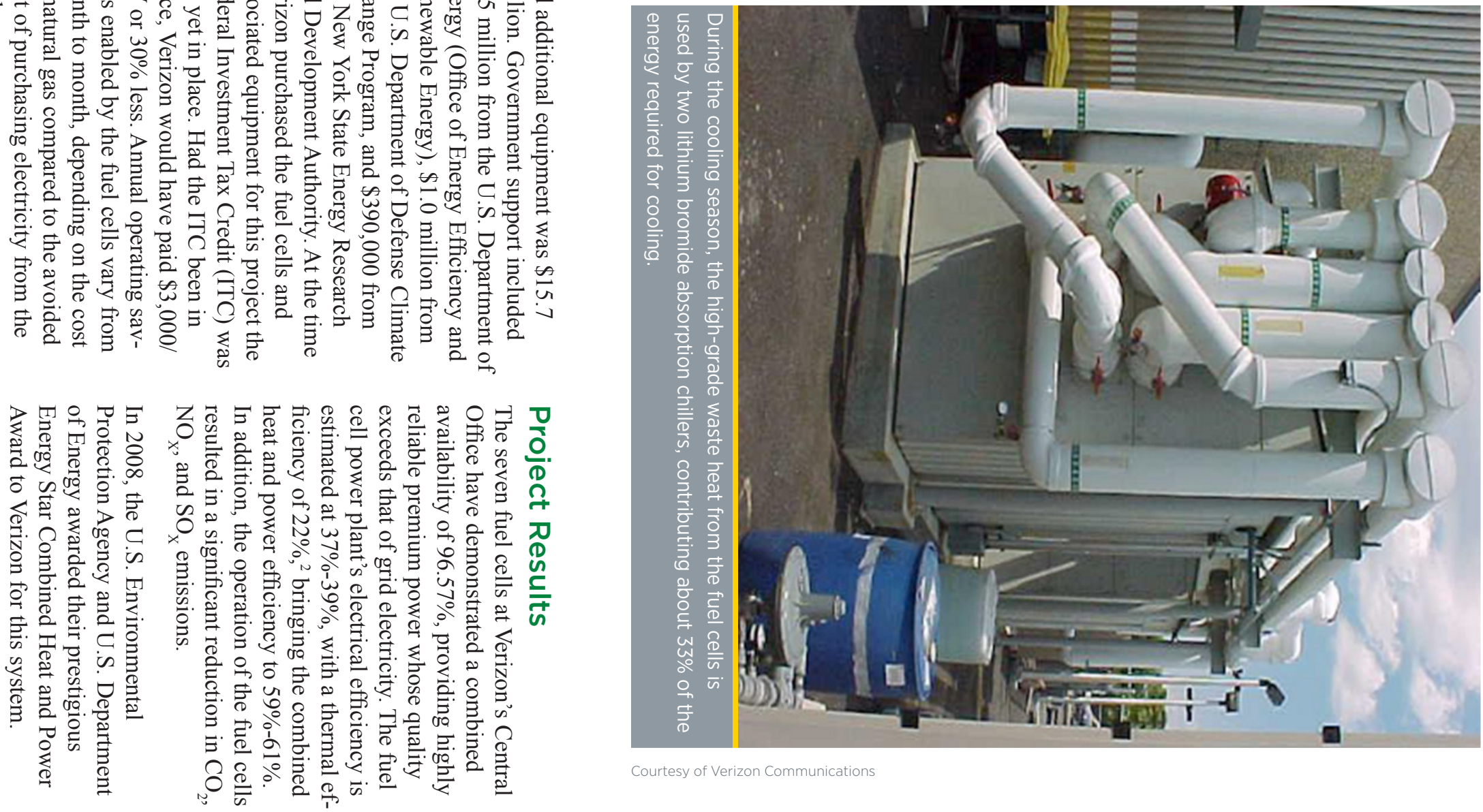

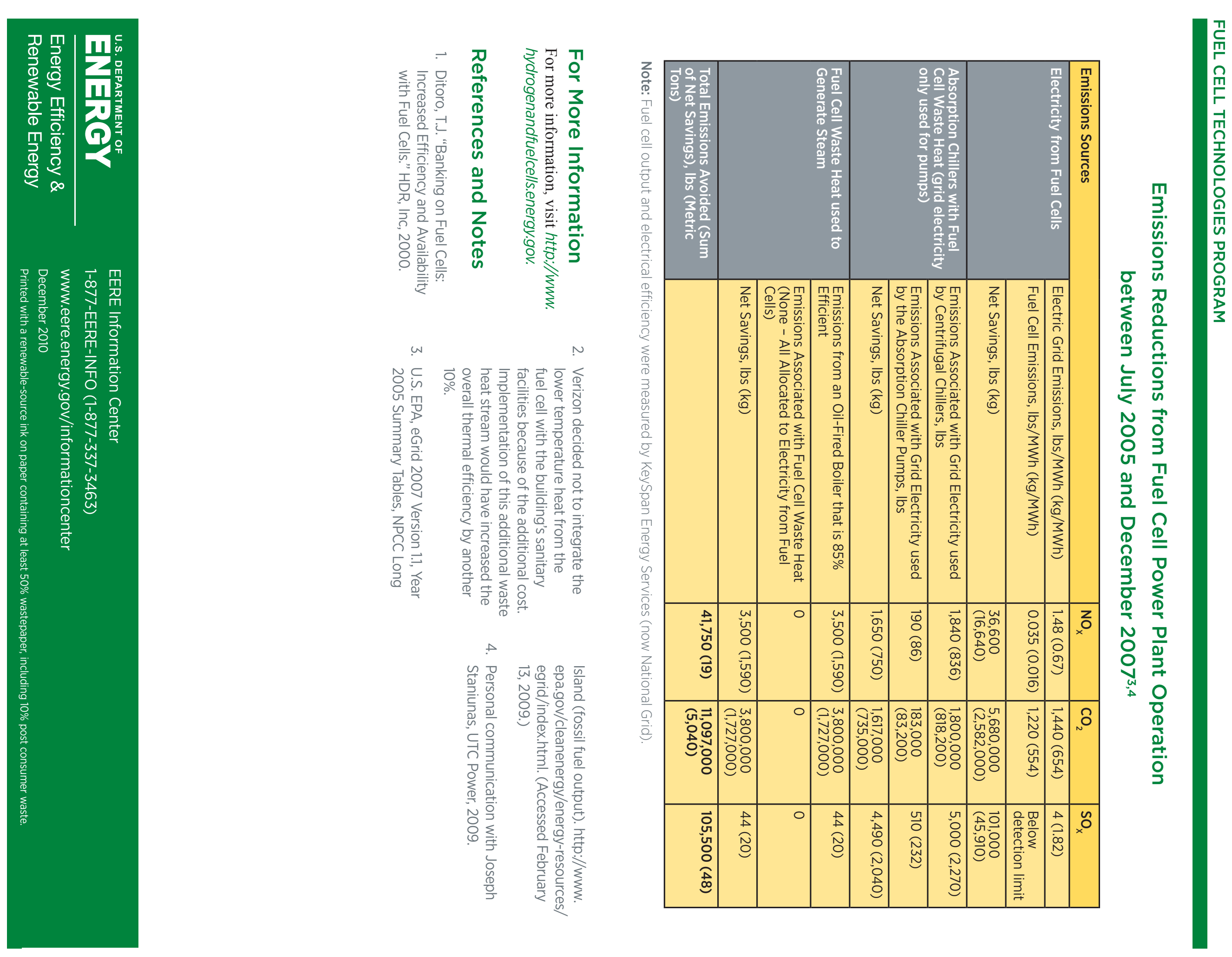


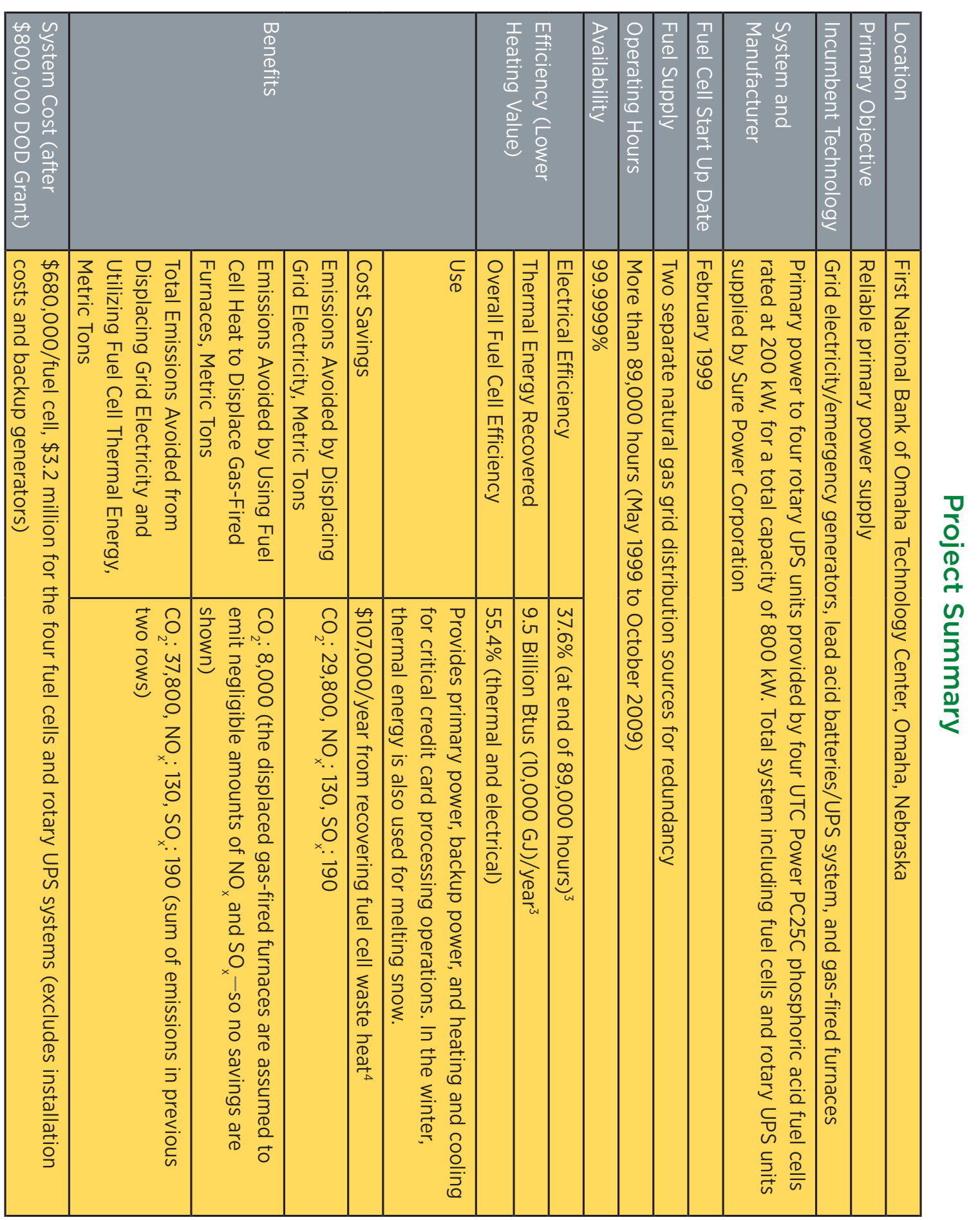

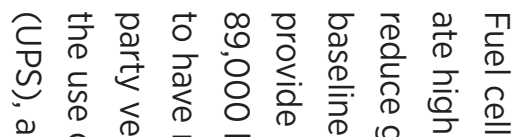

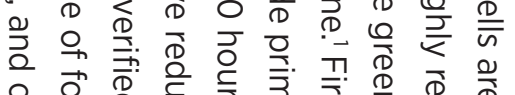

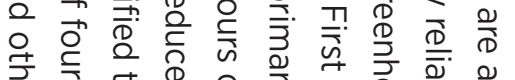

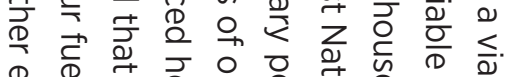

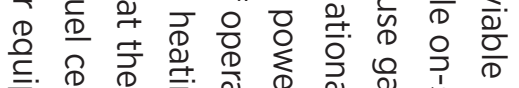

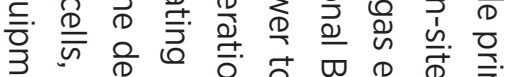

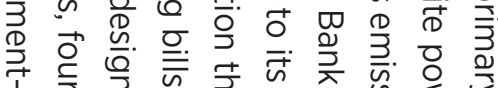

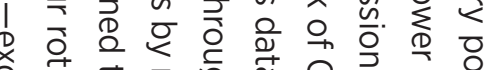

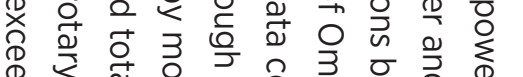

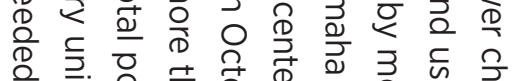

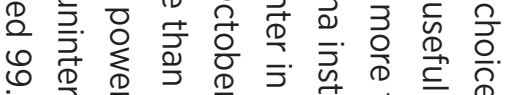

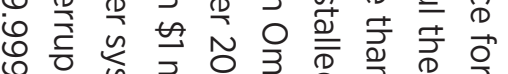

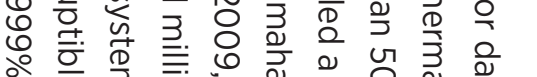

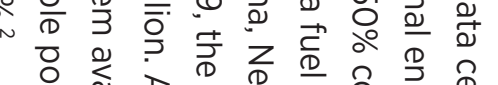

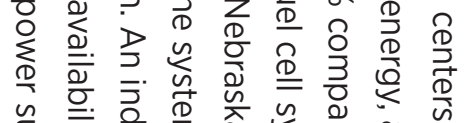

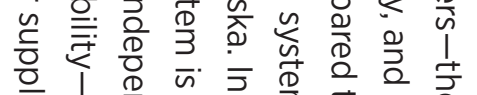

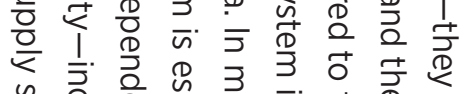

을 용

음 마를

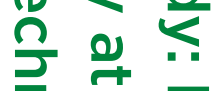
可范 음 꿀 ज的 $\frac{0}{0}$

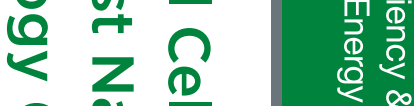
运 辛

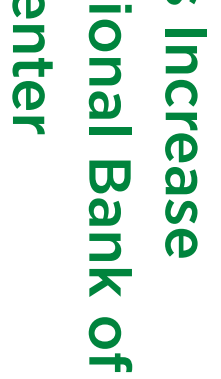

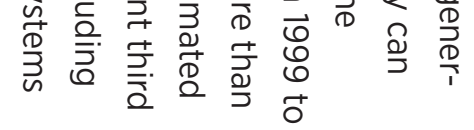

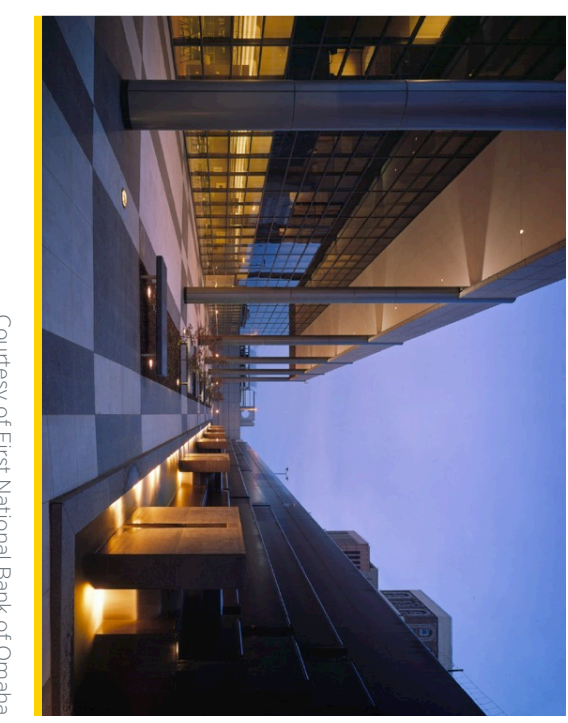



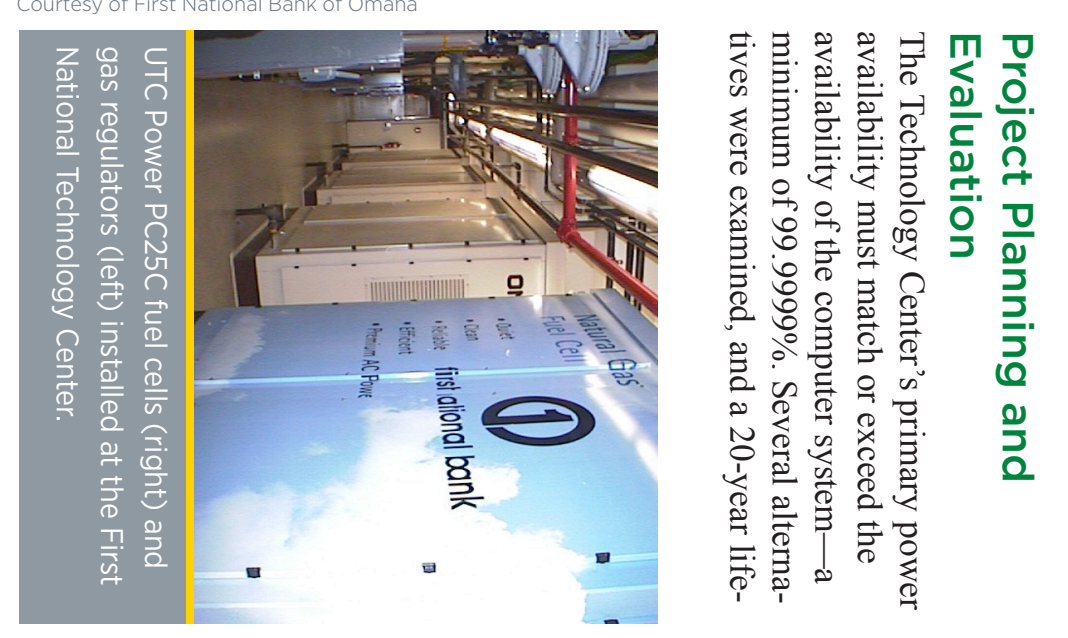

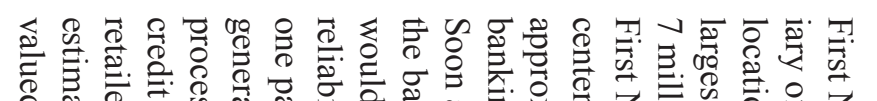
等

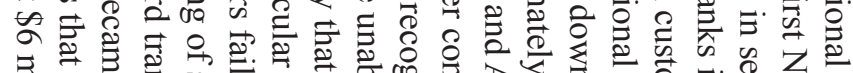

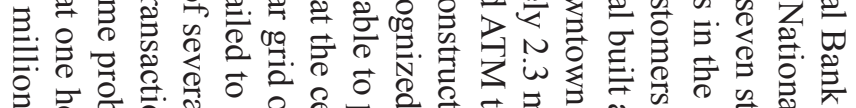

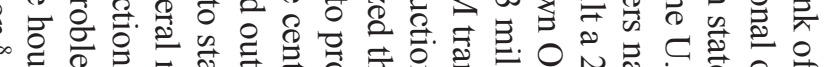

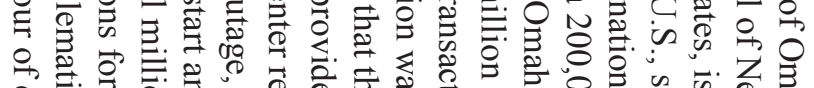

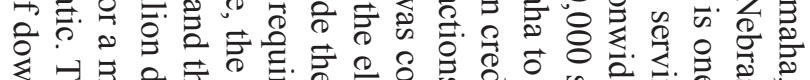

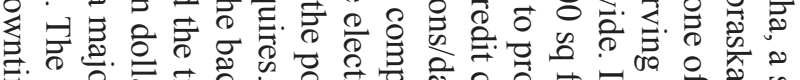

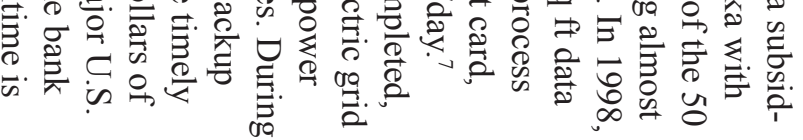

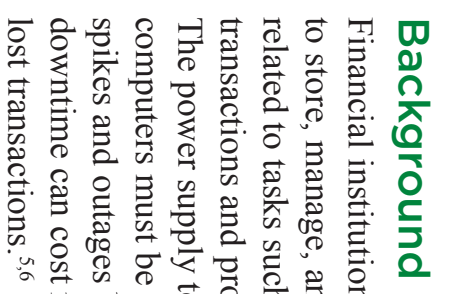
要. E.

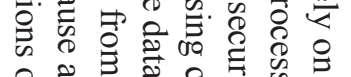

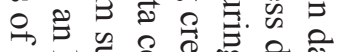

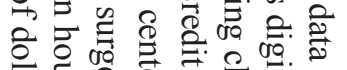

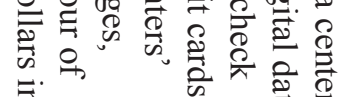

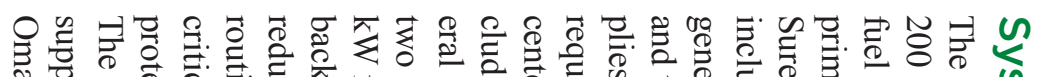

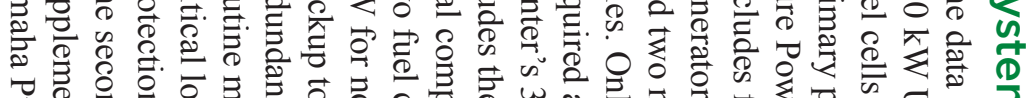

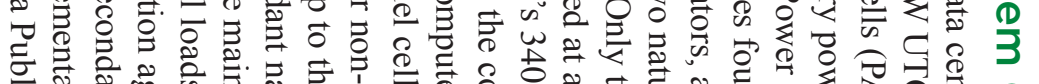

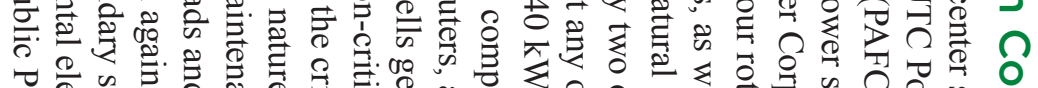

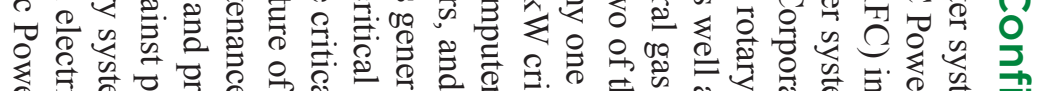

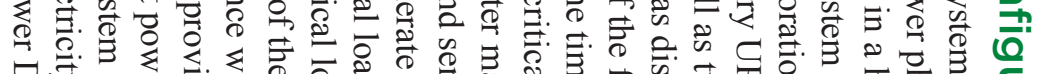

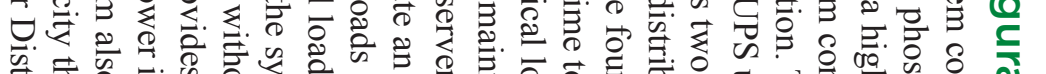

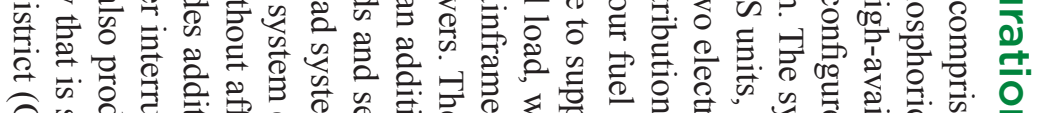

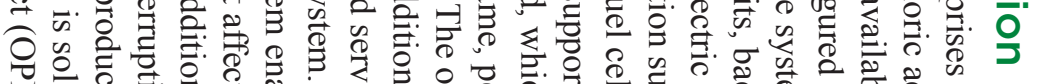

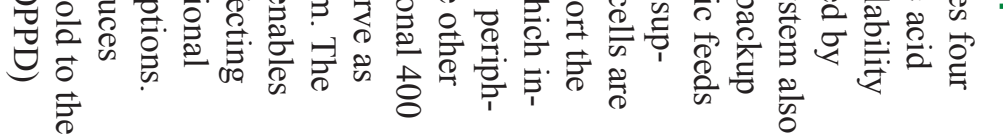

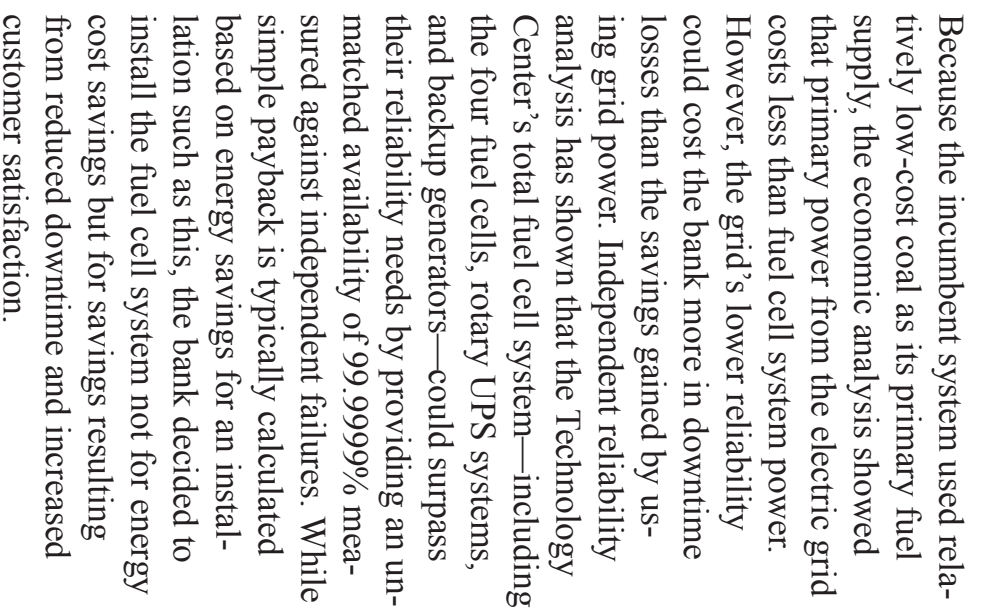

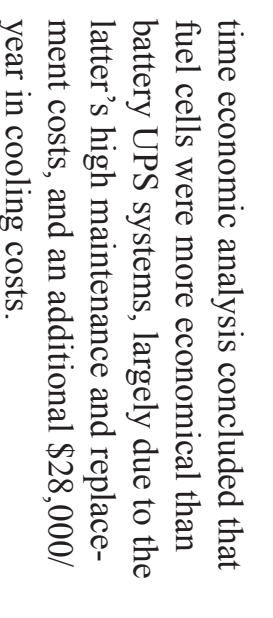

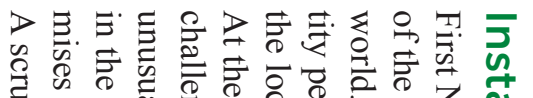

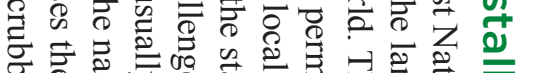

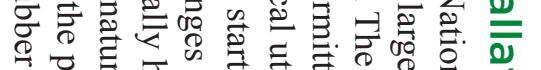

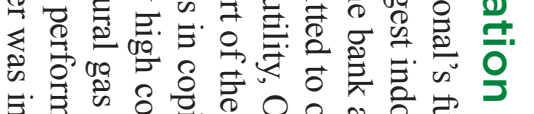
틀

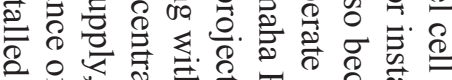

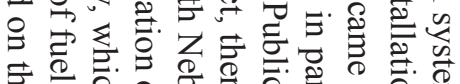

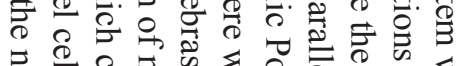

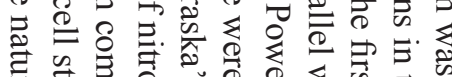

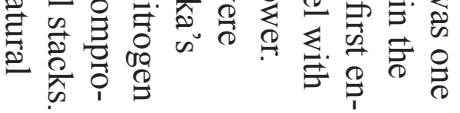

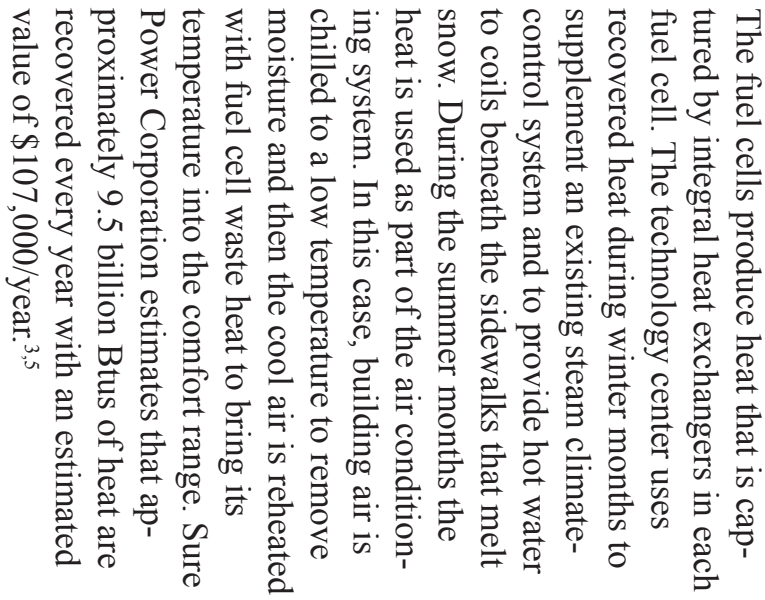

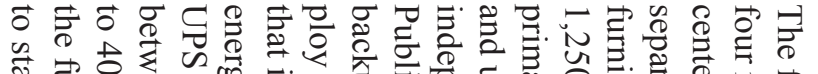

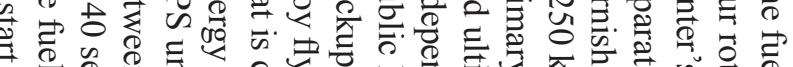

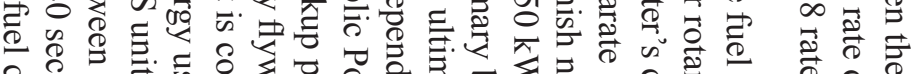

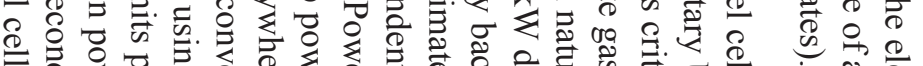

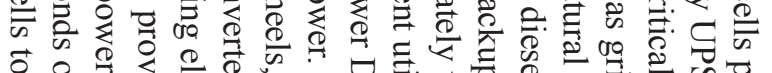

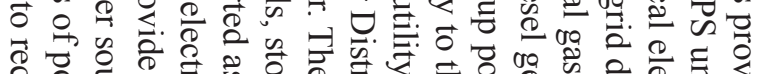

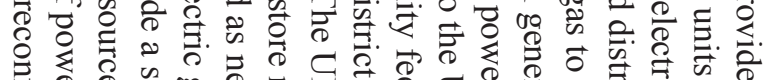

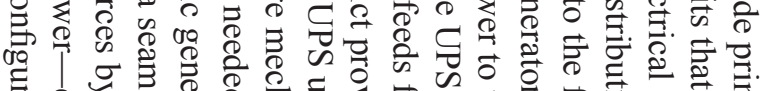

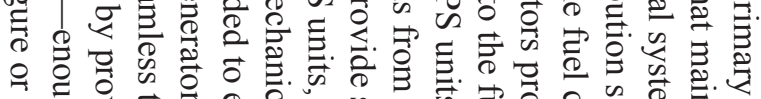

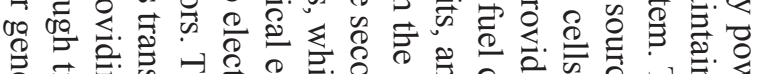

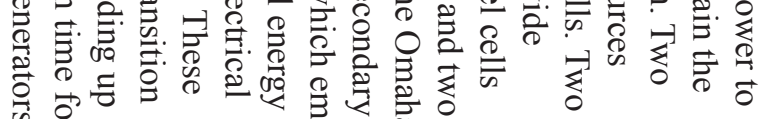

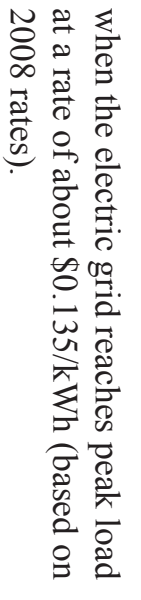




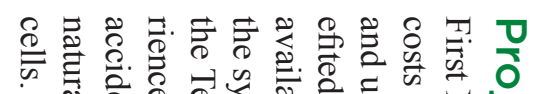

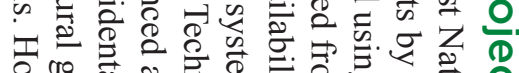

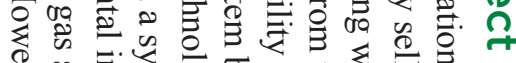

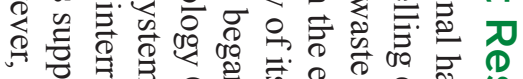

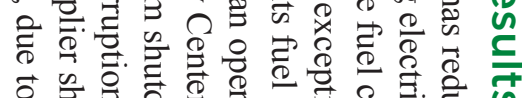

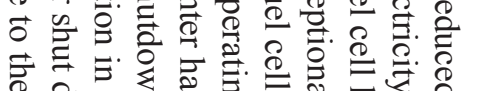
के 0 \%

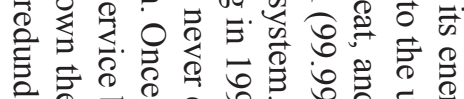

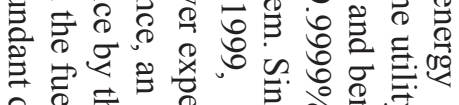

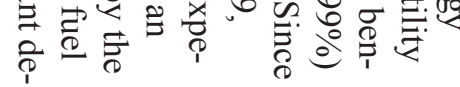

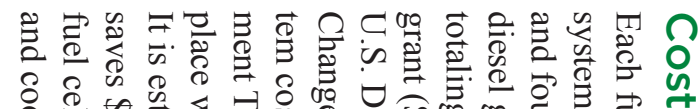

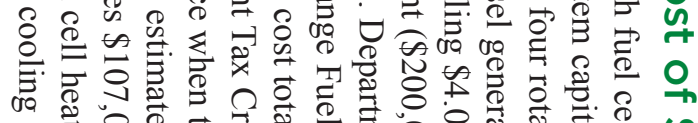

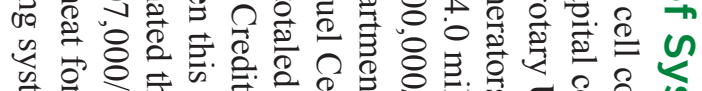

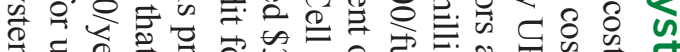
o.

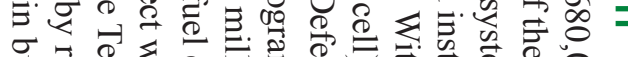

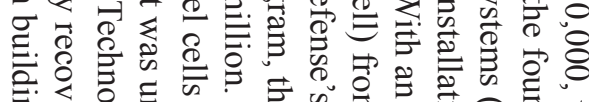

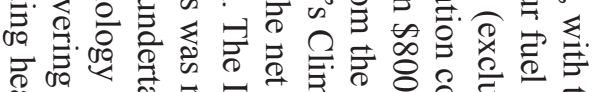

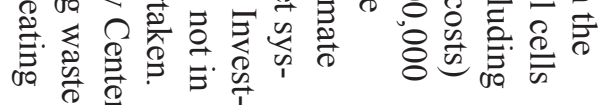

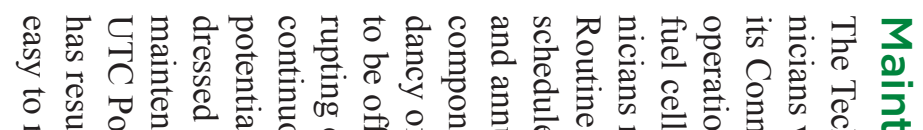

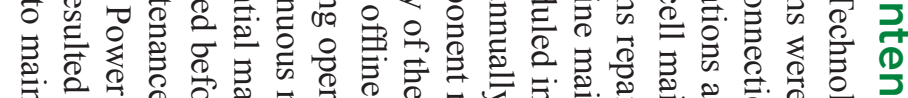

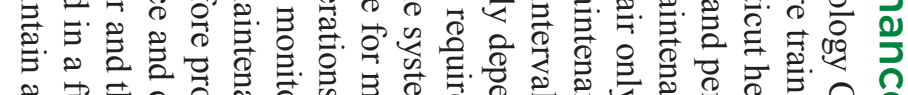

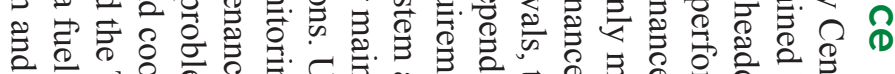

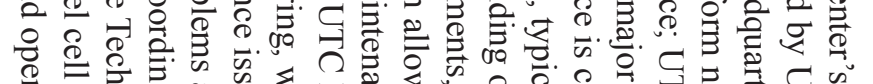

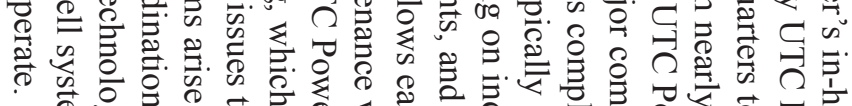

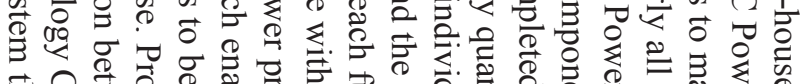

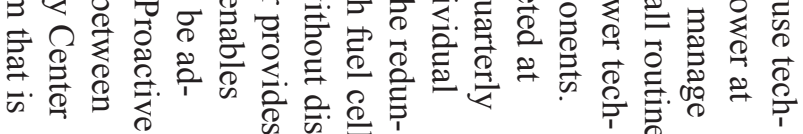
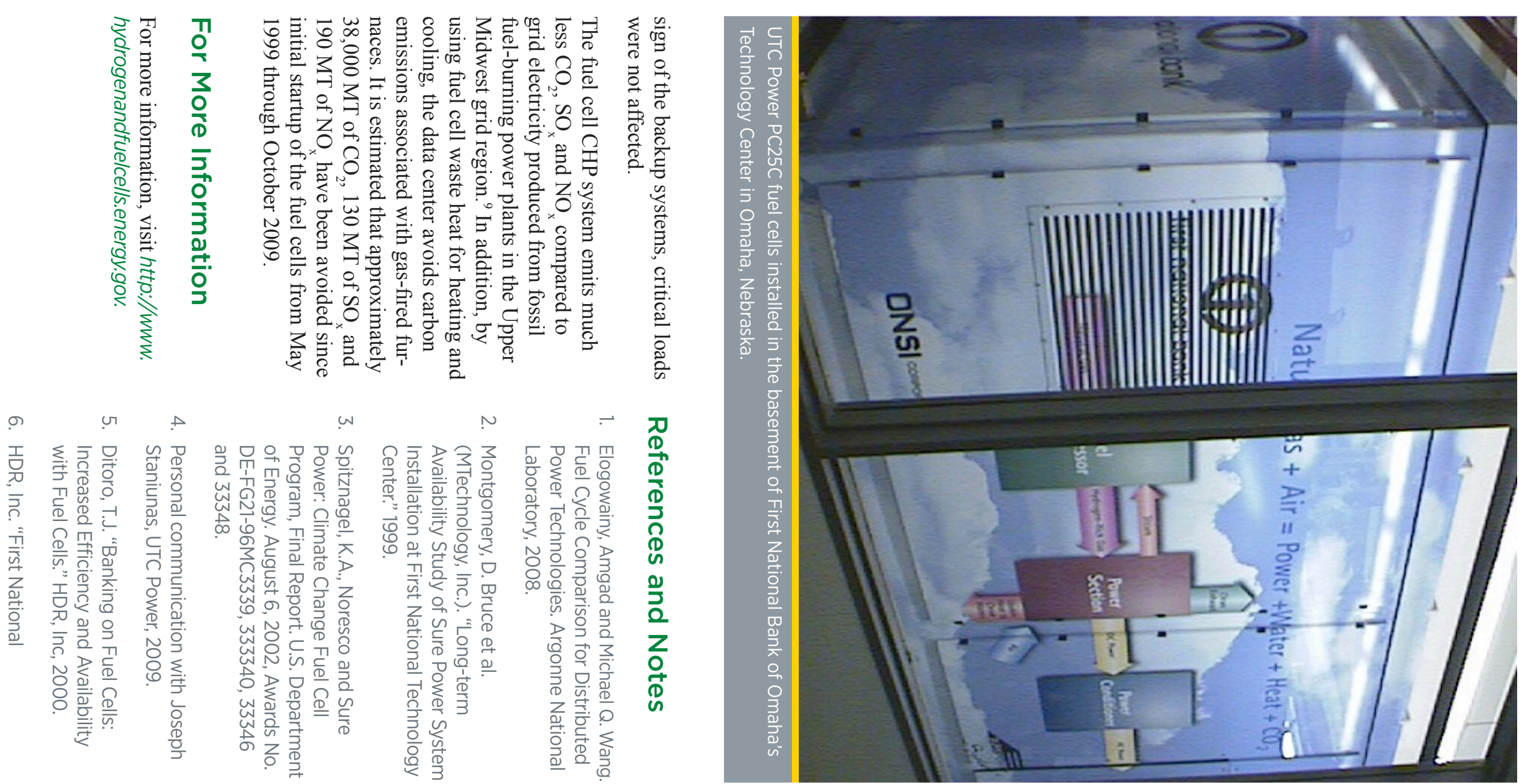

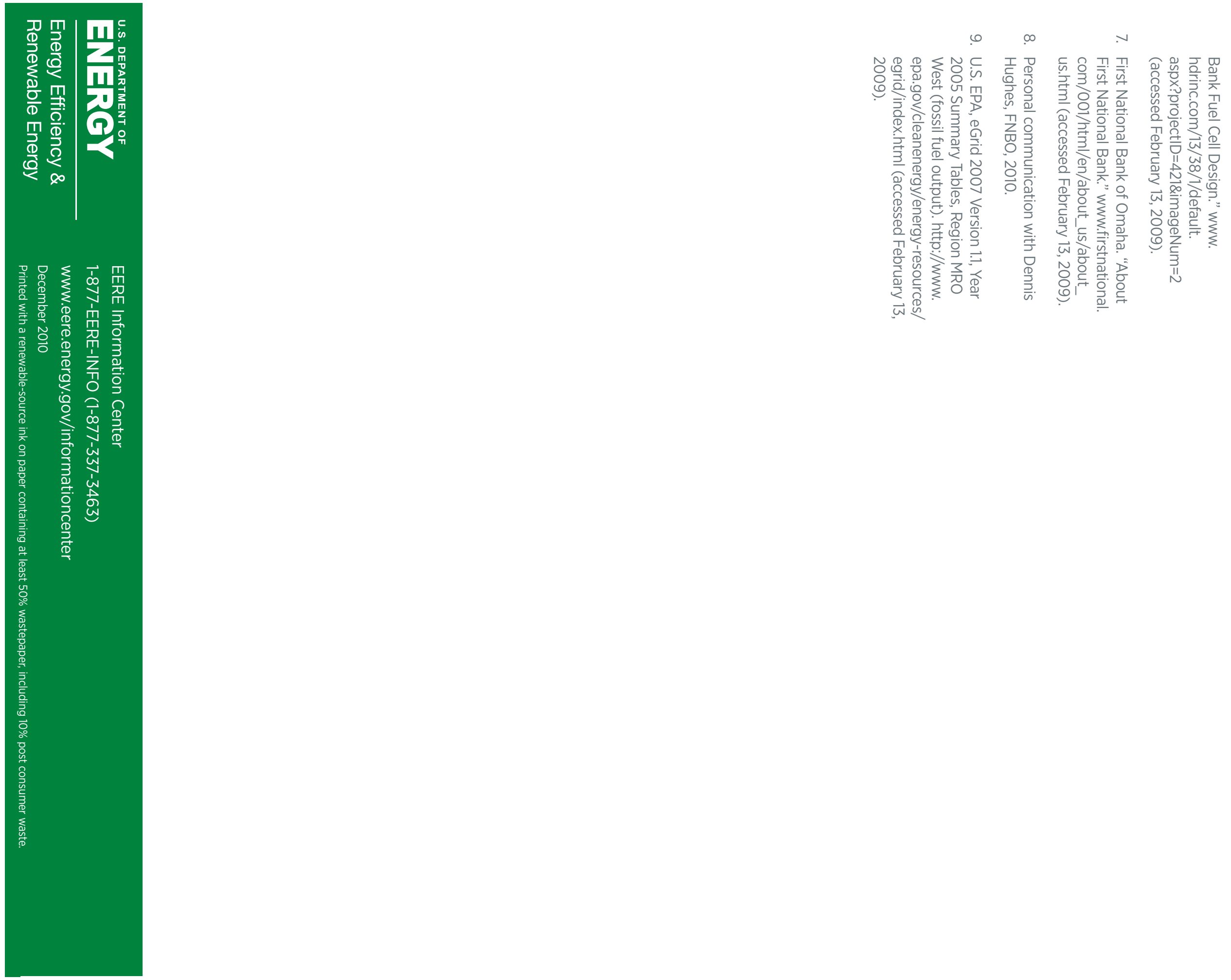


\section{Combined heat and power for}

\section{Supermarket}

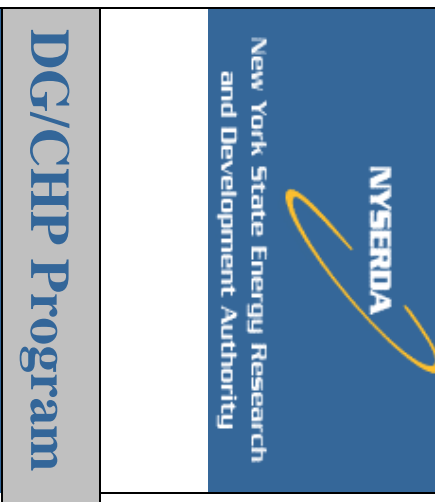

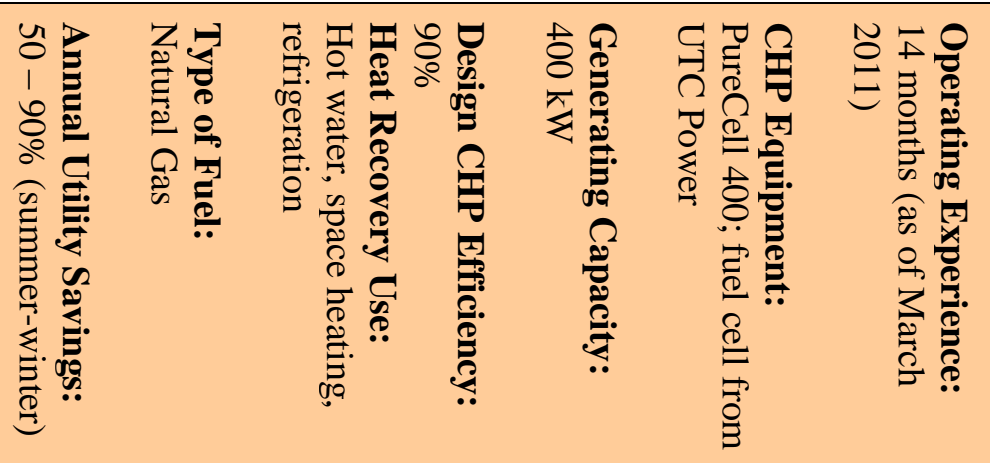
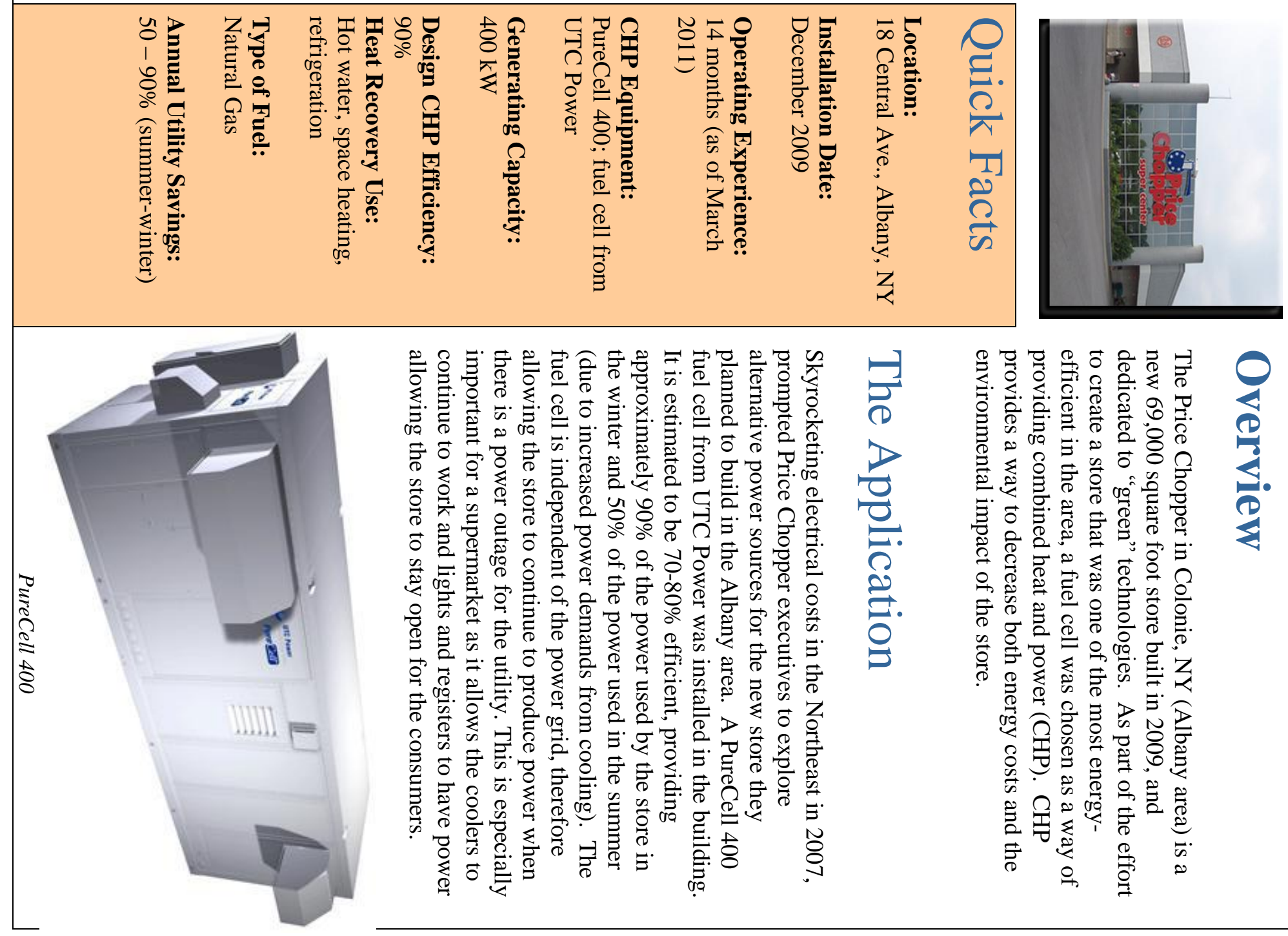

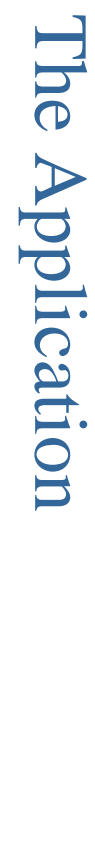
$\sigma$
0
0

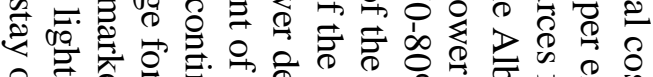

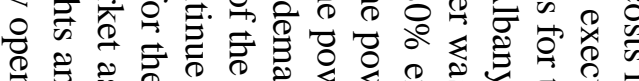

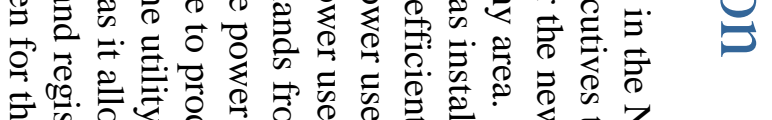

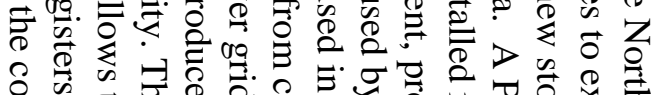

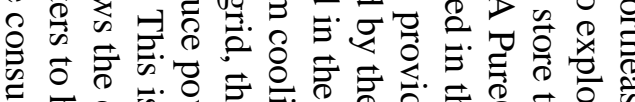

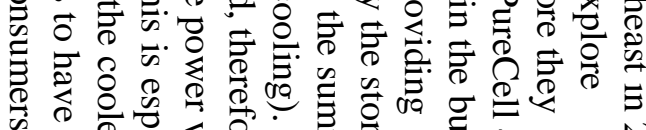

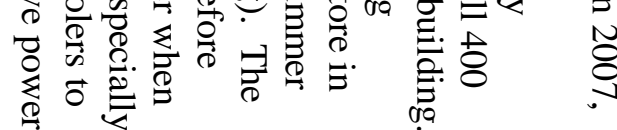

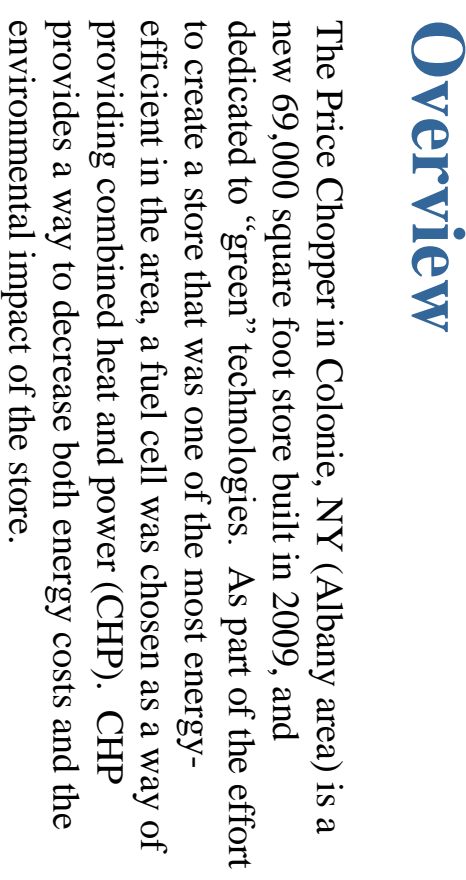

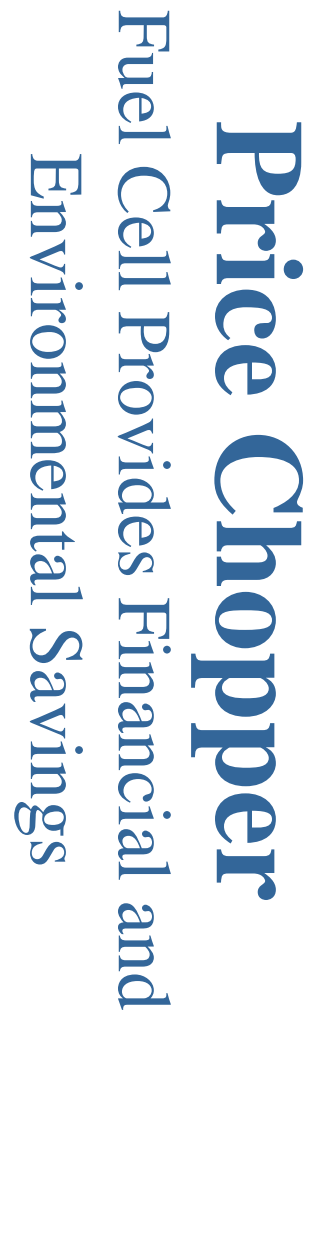




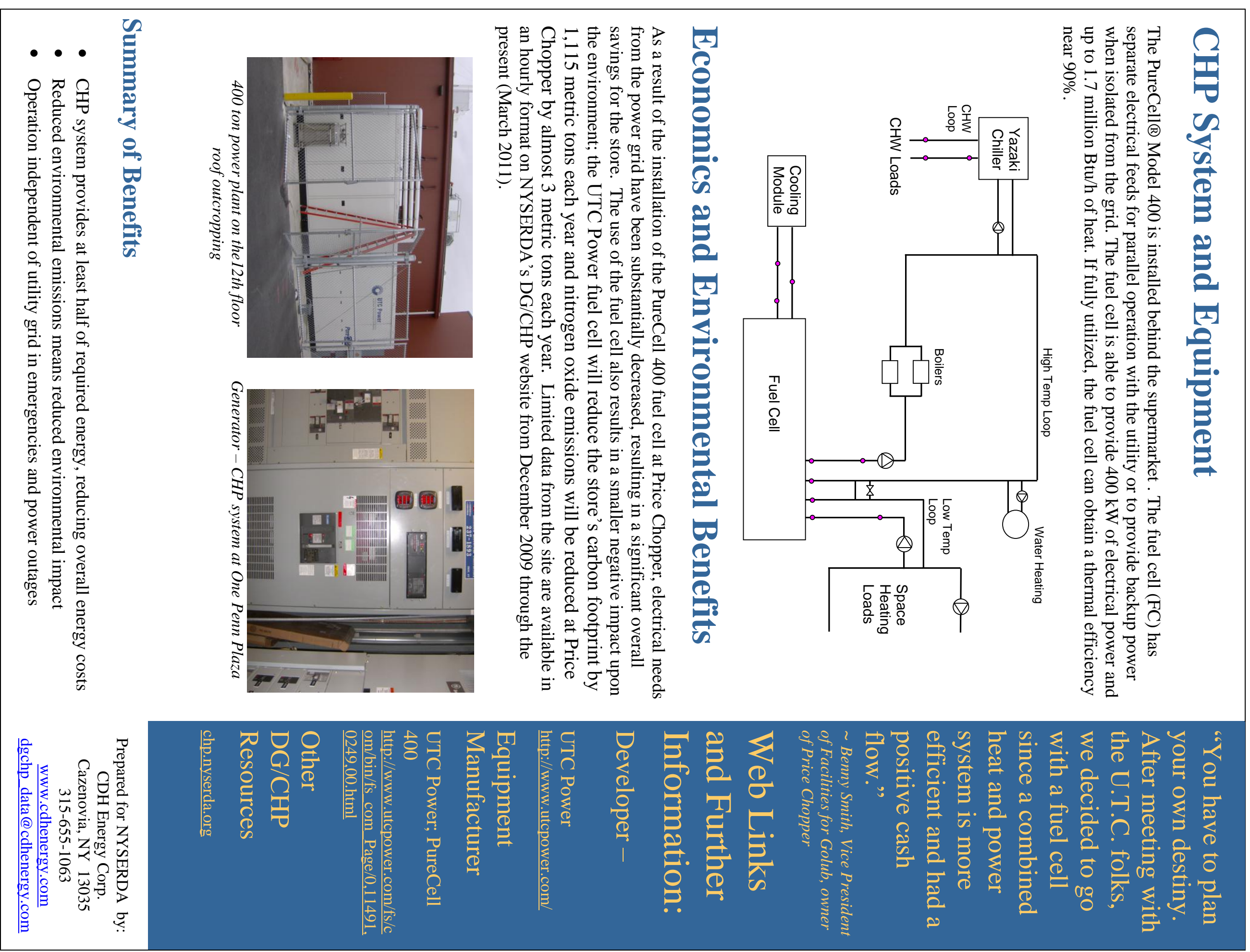




\section{Appendix E: Listing of States and Types of Incentives for Fuel Cells}

State Programs and Incentives for Fuel Cell CHP Source: Fuel Cell 2000's report, "State of the States: Fuel Cells in America 2011." Available at at the DOE Fuel Cell Technologies Program website: http://www1.eere.energy.gov/hydrogenandfuelcells/pdfs/stateofthestates2011.pdf

\begin{tabular}{|c|c|c|c|}
\hline State & $\begin{array}{c}\text { Portfolio } \\
\text { Standards that } \\
\text { include Fuel Cells }\end{array}$ & Tax Incentives & State Grants/Loans \\
\hline \multicolumn{4}{|l|}{ Alabama } \\
\hline Alaska & & & $\checkmark$ \\
\hline Arizona & $\checkmark$ & $\checkmark$ & \\
\hline Arkansas & $\checkmark$ & $\checkmark$ & \\
\hline California & $\checkmark$ & $\checkmark$ & $\checkmark$ \\
\hline Colorado & $\checkmark$ & $\checkmark$ & $\checkmark$ \\
\hline Connecticut & $\checkmark$ & $\checkmark$ & $\checkmark$ \\
\hline Delaware & $\checkmark$ & $\checkmark$ & $\checkmark$ \\
\hline District of Columbia & $\checkmark$ & & \\
\hline Florida & & $\checkmark$ & $\checkmark$ \\
\hline Georgia & & $\checkmark$ & \\
\hline Hawaii & $\checkmark$ & $\checkmark$ & $\checkmark$ \\
\hline Idaho & $\checkmark$ & $\checkmark$ & \\
\hline Illinois & & & $\checkmark$ \\
\hline Indiana & & $\checkmark$ & $\checkmark$ \\
\hline lowa & $\checkmark$ & $\checkmark$ & $\checkmark$ \\
\hline Kansas & $\checkmark$ & & \\
\hline Kentucky & & $\checkmark$ & \\
\hline Louisiana & & $\checkmark$ & \\
\hline Maine & $\checkmark$ & & $\checkmark$ \\
\hline Maryland & $\checkmark$ & & \\
\hline Massachusetts & $\checkmark$ & $\checkmark$ & $\checkmark$ \\
\hline Michigan & & $\checkmark$ & $\checkmark$ \\
\hline Minnesota & $\checkmark$ & $\checkmark$ & $\checkmark$ \\
\hline
\end{tabular}




\begin{tabular}{|c|c|c|c|}
\hline State & $\begin{array}{c}\text { Portfolio } \\
\text { Standards that } \\
\text { include Fuel Cells }\end{array}$ & Tax Incentives & State Grants/Loans \\
\hline Mississippi & & & $\checkmark$ \\
\hline Missouri & $\checkmark$ & $\checkmark$ & $\checkmark$ \\
\hline Montana & $\checkmark$ & $\checkmark$ & $\checkmark$ \\
\hline Nebraska & $\checkmark$ & & $\checkmark$ \\
\hline Nevada & $\checkmark$ & $\checkmark$ & $\checkmark$ \\
\hline New Hampshire & $\checkmark$ & & $\checkmark$ \\
\hline New Jersey & $\checkmark$ & $\checkmark$ & $\checkmark$ \\
\hline New Mexico & $\checkmark$ & $\checkmark$ & $\checkmark$ \\
\hline New York & $\checkmark$ & $\checkmark$ & $\checkmark$ \\
\hline North Carolina & $\checkmark$ & $\checkmark$ & $\checkmark$ \\
\hline North Dakota & $\checkmark$ & $\checkmark$ & $\checkmark$ \\
\hline Ohio & $\checkmark$ & $\checkmark$ & $\checkmark$ \\
\hline Oklahoma & & & $\checkmark$ \\
\hline Oregon & $\checkmark$ & $\checkmark$ & $\checkmark$ \\
\hline Pennsylvania & $\checkmark$ & $\checkmark$ & $\checkmark$ \\
\hline Rhode Island & $\checkmark$ & $\checkmark$ & $\checkmark$ \\
\hline South Carolina & & $\checkmark$ & $\checkmark$ \\
\hline \multicolumn{4}{|l|}{ South Dakota } \\
\hline \multicolumn{4}{|l|}{ Tennessee } \\
\hline Texas & & & $\checkmark$ \\
\hline Utah & & $\checkmark$ & $\checkmark$ \\
\hline Vermont & $\checkmark$ & $\checkmark$ & $\checkmark$ \\
\hline Virginia & & $\checkmark$ & \\
\hline Washington & & $\checkmark$ & $\checkmark$ \\
\hline West Virginia & $\checkmark$ & & \\
\hline Wisconsin & $\checkmark$ & $\checkmark$ & \\
\hline Wyoming & & $\checkmark$ & \\
\hline
\end{tabular}




\section{Appendix F: Acronyms and Abbreviations}

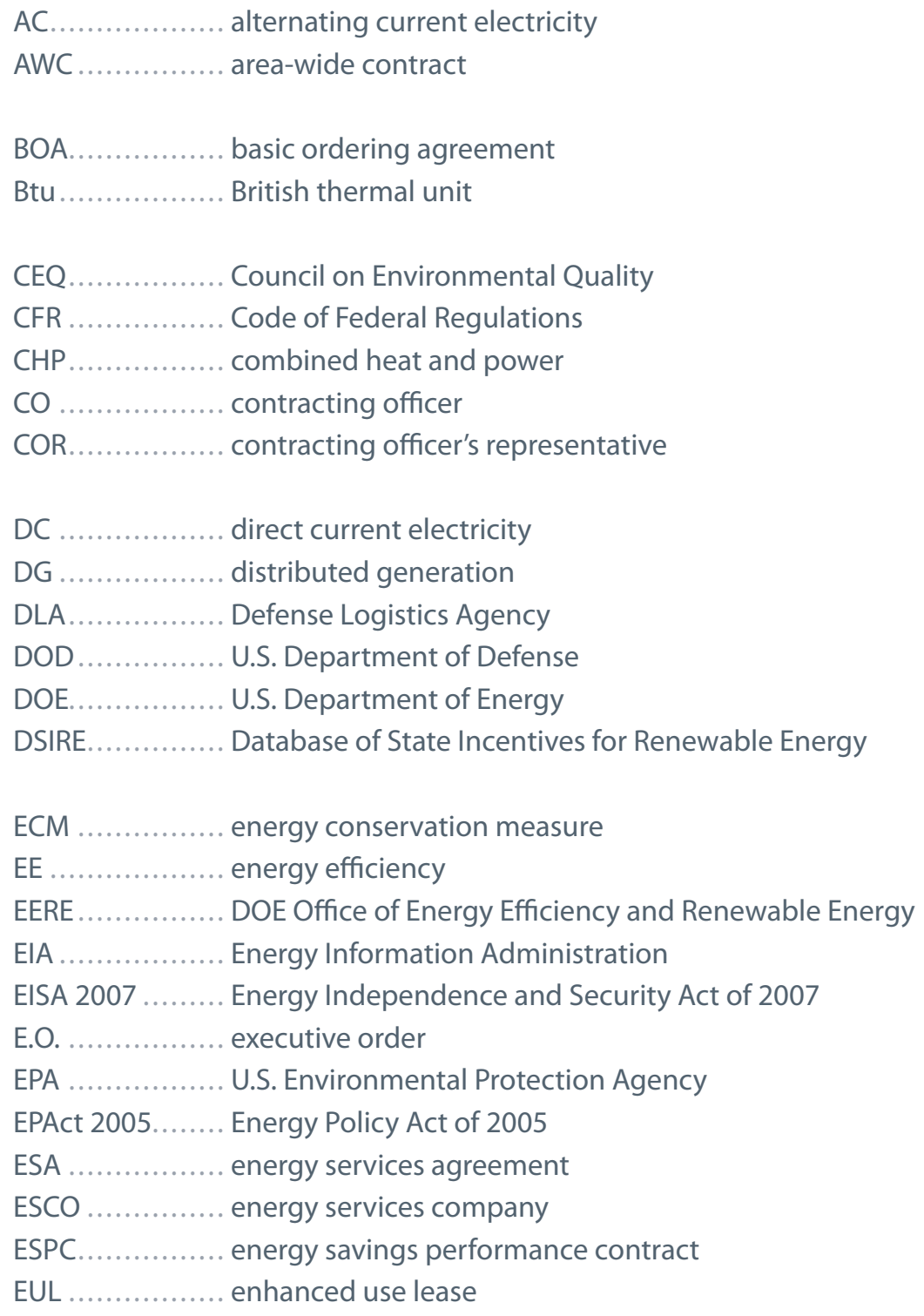

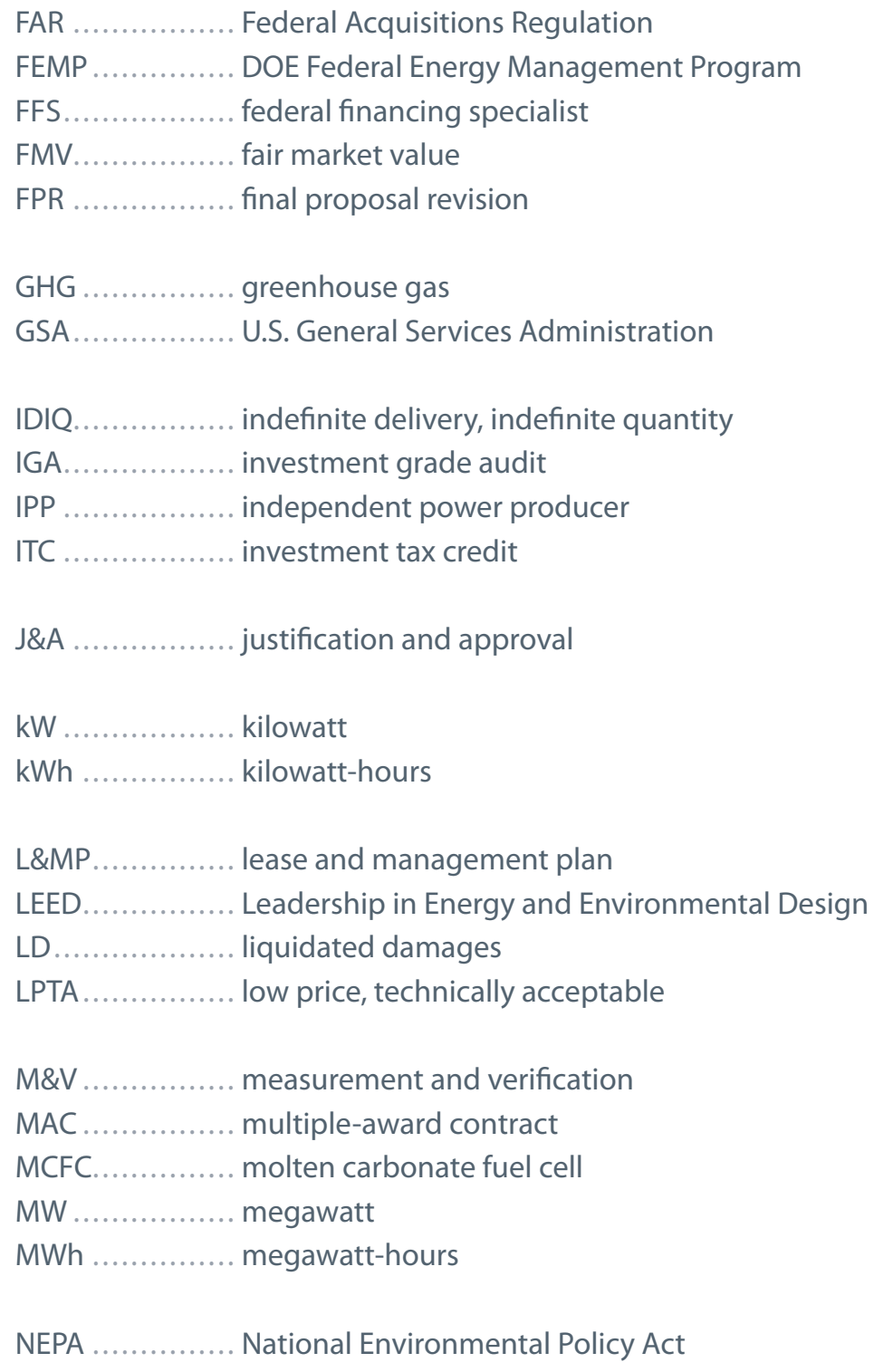




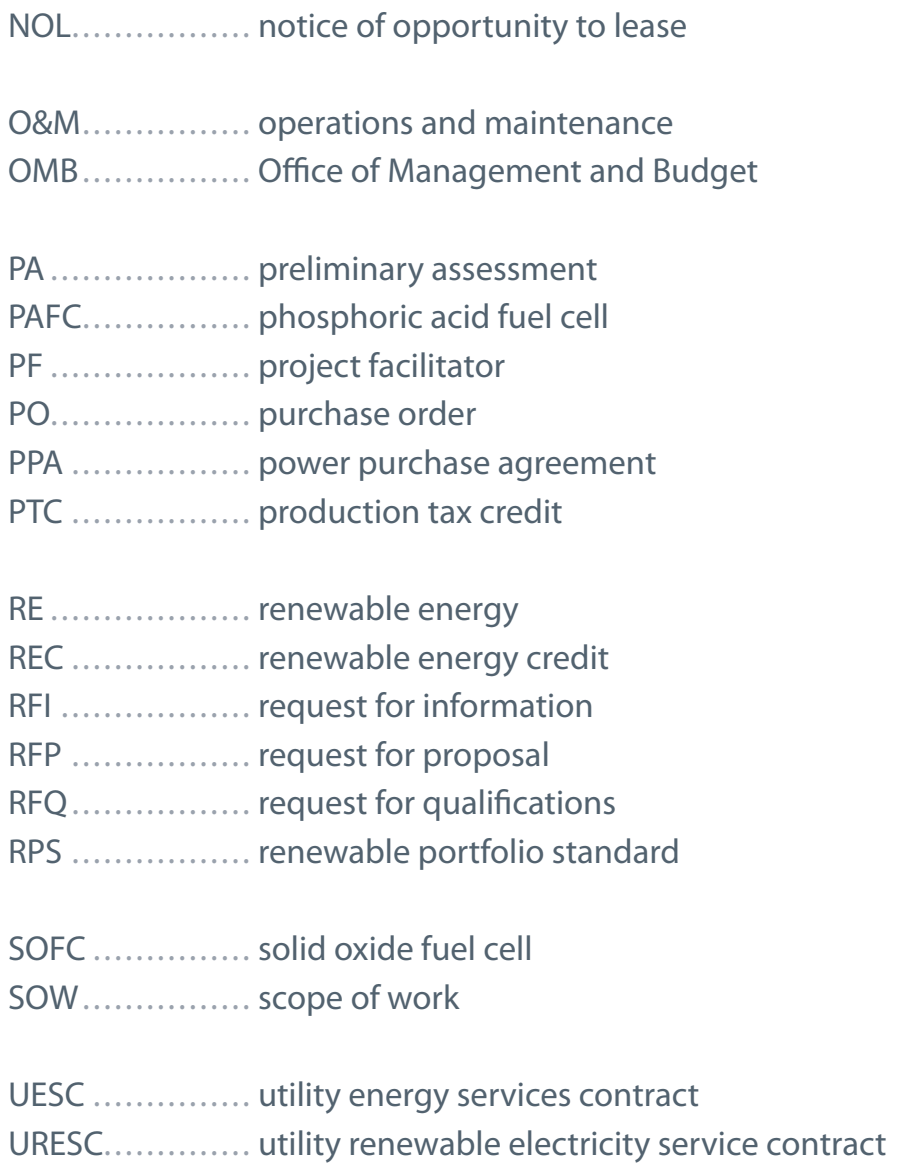




\section{U.S. DEPARTMENT OF Energy Efficiency \& \\ Renewable Energy}

For more information contact:

EERE Information Center

1-877-EERE-INFO (1-877-337-3463)

www.eere.energy.gov 